H. (1) 1.13 13. 4.

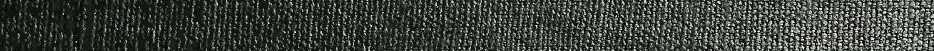

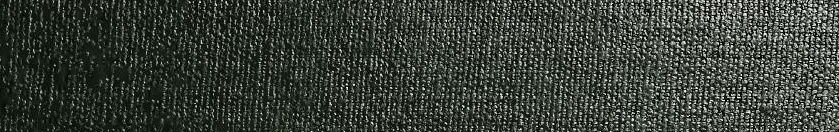

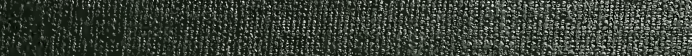

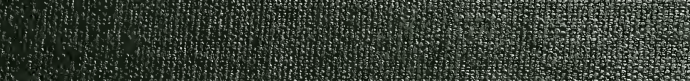

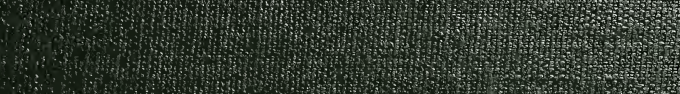
1.4

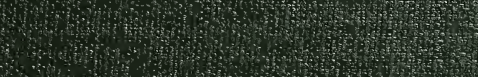
(1)

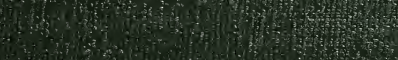

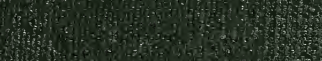
H. (6) (6) int 6. (3) 1. (1) 3. H(15) and

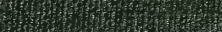
How

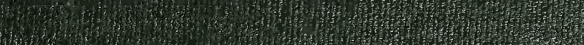

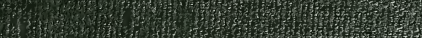
(1.2.

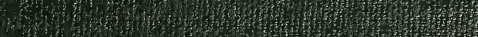

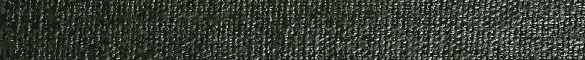

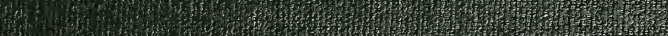

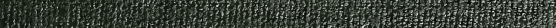

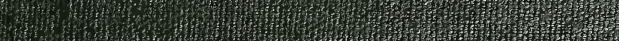

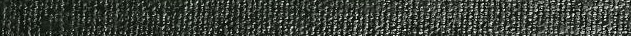

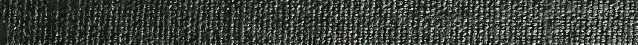

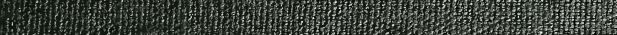

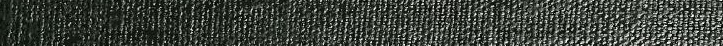
W.7.

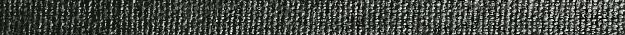
3.

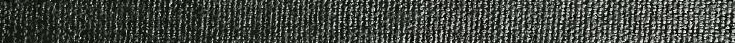

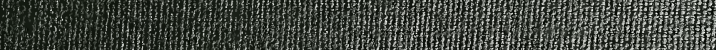

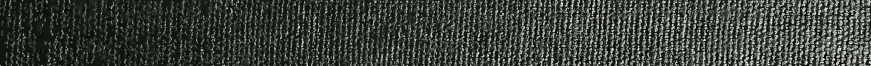

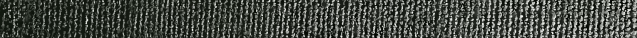




ART AND THE GREAT WAR 



\title{
AND THE GREAT WAR
}

\author{
By \\ ALBERT EUGENE GALLATIN \\ PAST CHAIRMAN COMMITTEE ON EXHIBITIONS, DIVISION OP \\ PICTORIAL PUBLICITY, UNITED STATES GOVERNMENT \\ COMMITTEE ON PUBLIC INFORMATION. PAST CHAIR' \\ MAN COMMITTEE ON ARTS \& DECORATION, \\ THE MAYOR'S COMMITTEE ON NATIONAL \\ DEFENSE, NEW YORK. AUTHOR OF \\ PORTRAITS OF WHISTLER, \\ छेc.
}

With One Hundred Illustrations
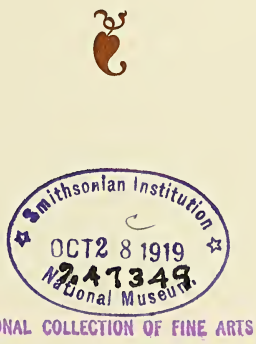

NEW YORK

E. P. DUTTON छ COMPANY

I9I9

NMAA/NPG LIBRARY

FEB 51991

SMITHSONIAN INSTITUTION 
COPYRIGHT, I9I9, BY E. P. DUTTON \& COMPANY ALL RIGHTS RESERVED

$$
\text { ชै }
$$

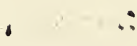

PRINTED IN THE UNITED STATES OF AMERICA 
DEDICATED

TO

MY MOTHER 



\section{PREFACE}

THE purpose of this book has been to chronicle the part played in the 1 Great War by painters, illustrators, etchers, lithographers and sculptors, acting in these capacities. Their services were of great value and certainly deserved to be recorded. Speaking of the service rendered by the art, ists, the Honorable Carter Glass, Secretary of the Treasury, has said: "The whole civilized world owes thanks to the artists of America. Future history would be incomplete without adequate recognition of the mighty concrete values which the artists of the war wrung from the fabrics of their dreams and devoted to the rescue of humanity from further bloodshed and sacrifice."

I have endeavored to show what the artists of the United States, Great Britain, Canada and France have done, both in depicting scenes at the actual front and behind the lines, in recording the work of the navies and the aviation corps, as well as depicting scenes in the shipyards, munition factories, industrial plants and work on the land. I have, too, tried to show the important service rendered by the poster artist, the cartoonist and the camoufleur.

With regard to the illustrations appearing in this book, it has been my endeavor to make them record as many phases as possible of the Great War, and to select only those possessed of artistic interest.

Already a considerable literature has come into existence concerning the part artists played in the Great War; in my bibliography I have re. corded such items as have come to my notice. Many of these items I have consulted in the preparation of the following pages.

My best thanks are due to the British Bureau of Information for their courtesy in supplying me with photographs of many of the British pictures. I wish also to thank Mr. Eric Brown, Director of the National Gallery 
of Canada, for his kindness in sending me desired information concerning the Canadian War Memorials. To Mr. Paul G. Konody, who brought this exhibition to New York, I am indebted for giving me several photographs of the Canadian paintings. My thanks are also due to $\mathrm{Mr}$. Duncan Phillips for his courtesy in placing several negatives belonging to him at my disposal, and to Mr. H. W. Sage for permitting me to reproduce the paintings by Mr. Maxfield Parrish, of which he is the owner.

Bar Harbor, Maine, August, I9I9

A. E. Gallatin 


\section{CONTENTS}

Introduction

Art and the Great War-Former War Pictures-British and Canadian Records-America's Failure to Make Adequate Pictorial RecordsArt Museums and the War-American Federation of Arts-National Arts Committee-Mr. Gallatin's Letter to the President.

Chapter One: The United States of America $3 I-56$

Division of Pictorial Publicity-Posters-Official Artists-Other Artists in France--Records Made in America-War Pictures Painted in America - Cartoons-Designation Targets - Sculpture-Military Camouflage-Marine Camouflage-New York Committee on Arts and Decoration-Art Committee of New York Liberty Loan CommitteeAllied War Salon-Victory Arch, New York; Victory Way in New York.

Illustrations: The United States of America

Chapter Two: Great Britain and Canada I3I'I43

The Excellent Records Possessed by Great Britain and Canada-Official British Artists-Lithographs Depicting Great Britain's Efforts and Ideals-Work of G. Spencer Pryse and other Artists-Canadian War Memorials; Official Australian Artists.

Illustrations: Great Britain and Canada

Chapter Three : France $219-228$

Work of Steinlen and Forain-Lucian Jonas and Henri Farré-Other

War Pictures-Posters.

ILLUSTRATIONS: France 229-277

ILLUSTRATIONS: The Netherlands $279-283$

BIBLIOGRAPHY $285-288$ 



\section{LIST OF ILLUSTRATIONS}

\section{\&}

THE UNITED STATES OF AMERICA

Grorgr Luks The "Blue Devils" Marching Down Fifth Avenue. Oil. Reproduced in color. Frontispiece

Grorgr Luks Peace Celebration in New York. Oil

Spencer B. Nichols The Tanker. Oil

Edwin H. Blashfield Carry On. Oil

SAMURL J. Woolf First Aid Station at Seicheprey. Oil

John C. Johansen The Launch of the Watonwan. Oil

Henry Reuterdahl The Destroyer Patrol. Oil

Henry Reutrrdahl The Return of the Victory Fleet. Drawing

Childe Hassam Early Morning on Fifth Avenue, May, 1917. Oil

Grorge Bellows Murder of Edith Cavell. Lithograph

Grorge Beliows Massacre at Dinant. Oil

Maxpield Parrish Design for the Red Cross. Oil

MaxpIeld Parrish Design for the Red Cross: Detail. Oil

Maxpield Parrish Design for the Red Cross: Detail. Oil

Harry E. Townsend A Wounded Tank. Drawing

George Harding An American-French Conference in a Wine Cellar; Château-Thierry. Drawing

Walter J. Duncan Cold Nights Coming On. Drawing

ERnest Peixotro Troops Leaving Esnes, September 23, 1918

HARvey DunN Kamarad-The Sniper. Drawing

J. André Smith On Hill 204-Southwest of Château-Thierry. Drawing

William J. Aylward Troops Waiting to Advance at Hatton-Châtel, Meuse-S. Mihiel Drive. Drawing

Wallace Morgan Americans Mopping $U_{p}$ in Cièrges. Drawing

Wallace Morgan Feed a Fighter. Poster

Joseph PenNell Ready to Start. Lithograph

Joseph Penneli Making Armor Plate (England). Lithograph

Joseph Pennel That Liberty Shall Not Perish from the Earth. Poster

Boardman Robinson The Serb. Drawing

Vernon Howr Bailey The Superdreadnoughts New York and Arizona. Lithograph

Thomas Hastings Victory Arch, New York

Paul Manship Jeanne d'Arc Medal

Mahonri Young One of the "Buffaloes." Bronze

C. B. Falls Books Wanted. Poster

Adolph Treidler Farm to Win "Over There." Poster

W. T. Benda For Motherland and Freedom. Poster

Henry Raleigh Halt the Hun! Poster

George Iliman Keep it Coming. Poster

George WRIGHT Another Ship-Another Victory

GREAT BRITAIN

William ORPEN A Grenadier Guardsman. Oil. Reproduced in color

William Orpen Horses Near Aubigny. Drawing 


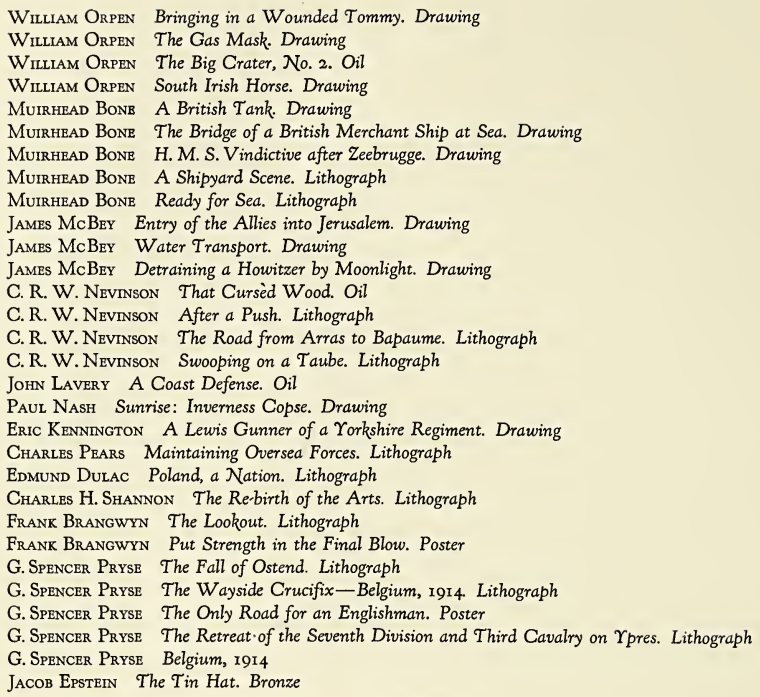

Norman Wilkinson Canada's Answer

\section{CANADA}

A. J. Munnings Horses Watering Near Domart

D. Y. CAMrron Flanders from Kemmel

LEONARd Richmond Canadian Railway Construction in France

P. Wyndham Lewis Canadian Gunpit

FRANCE

J. L. Forain The Prisoner. Lithograph. (From a poster)

J.L. ForaIN Forward! Lithograph

J. L. ForaIN What? Not Even a Child! Lithograph

J. L. Forain - It is a Neutral

-Ah!... I Breathe. Lithograph

Th. A. Steinlen L'Aisne Dévastée. Poster. Reproduced in color

Th. A. Sternsen Aid to the Wounded. Lithograph

Tн. A. SteInlen Under the Boot. Lithograph

TH. A. Stennlen Concert en Grange. Poster

TH. A. Sternlen La Triennale. Poster 
TH. A. Strinlen Leaving the German Jail. Lithograph

LuCien Jonas A Volunteer. Lithograph

Lucien Jonas Portraits of General Pershing. Drawings

Pierre Auguste Renoir Portrait of His Son, Wounded in the War. Drawing

Hermann Paul The American Hymn. Lithograph

Benrro For the Beautiful Land of France. Lithograph

Benito The Conquerors of the Marne. Lithograph

BenrTo The Heart of America. Lithograph

Henri Farré Bombing Nancy. Oil

Antonin Mercí Plaquette de la Fraternité des Artistes. Gilded bronze

"SEM" Pour le Dernier 2uart d'Heure. Poster

"Sем" Pour le Triomphe Souscrivez à l'Emprunt National. Poster

Grorges Scott Pour le Drapeau! Pour la Victoire! Poster

Aber Farvre On les Aura! Poster

Abel Fatvre L'Or Combat Pour La Victoire. Poster

Adolphe Willettr Journées Girondines. Poster

Francisque Poulbot - N'oublie pas de souscrire ... pour la Victoire! .. e et le retour! Poster

\section{THE NETHERLANDS}

Louis Raemarkers Cleansing the Temple. Lithograph

LouIs RAemaekers The American Army in France-The Relief. Pencil and watercolor 



\section{ART AND THE GREAT WAR}

\section{INTRODUCTION}

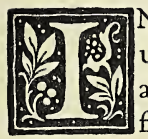

$\mathrm{N}$ the prosecution of the Great War, and bringing about ultimate victory, the artists of the United States and the allied countries played a very important part. This was the first war artists, as such, were used by their governments, and art became a powerful weapon.

To the artists was intrusted the extremely important task of organizing the camouflage corps of the armies, and on their shoulders also fell the work of developing the art of marine camouflage, both of which tasks they did with marked success. In the recruiting of troops and in the raising of government loans, as well as for many other purposes, including relief, the artists through their posters rendered a very notable service. The cartoonist was a powerful moulder of public opinion and it has been truthfully said of M. Louis RaEmaekers, the great Dutch artist and cartoonist, that "no oration, no literature, no art, has brought the real meaning of the war home so convincingly" as his cartoons. As will be brought out in the following pages, the artist also contributed in many other ways towards bringing the war to a successful conclusion.

Somewhere I have come across the statement that James Gillray, the English caricaturist, and Philippe Jacques de Loutherbourg were sent to Flanders in 1793 to commemorate the military exploits of the Duke of York. The latter artist was at one time court painter in France and afterwards, going to England, was elected a member of the Royal Academy. Garrick employed him to design scenery and he also painted several works dealing with military and naval episodes. Aside from this, as far as is known, the Great War was the first to be officially recorded by artists. This innovation is one that the historian and posterity will 
certainly welcome, for pictures, far more adequately than the written word, were capable of recording the great conflict.

The Great War was waged to a large extent with explosives and machinery-very different from the individual combat which the soldier of ancient Greece engaged in when he went into battle. It is a far cry from the athletic figures of Greek warriors on the frieze of the Parthenon to Mr.C.R.W.Nevinsos's painting which shows three men working a mitrailleuse down in a trench, barbed wire silhouetted against the sky. These three men are a part of their machine.

The hideousness and horror of modern trench warfare is also far removed from the pageantry and splendor of warfare in the Middle Ages - it is vastly different also from the comparatively picturesque and open warfare of the Napoleonic epoch. War pictures of to-day have almost no roots in the past; the pictorial recorder of modern warfare has had no sign-posts to guide him. For one thing, for the first time land scape formed an important feature of the war picture.

Leonardo da Vinci made many designs for fortifications and various implements of warfare; those familiar with Ravaisson-Mollien's folio volumes of facsimiles of Leonardo's manuscripts will remember that he even made a design for an aeroplane. Whatever our own opinion may be in the matter, we must remember that Leonardo always maintained that he had attained greater excellence as an engineer than as a painter or a sculptor, and it is in this character, rather than as an artist, that his services were of value to his country. The same is true of Michelangelo, who was possessed of similar accomplishments. The battle pictures of these two artists have perished.

One recalls the decorative and gorgeous battle pictures of Paolo Uccello and Raphael's Battle of Constantine. Such gay panoramas as these are very different from the trench warfare of the Great War. Dürer was also interested in depicting military matters; a work by him printed in Nuremberg in 1527 contains many engravings of fortifications, cannon and various military objects, which he drew on the wood. 
Velasquez's Surrender of Breda is the greatest military picture ever painted.

The horrors of war were truthfully and graphically set down by Callot and by Goya in their powerful etchings. The great Russian painter of warfare, Verestchagin, also completely stripped war of its glamor.

The paintings of Gérard and Gros are simply glorifications of $\mathrm{Na}$ poleon; as transcripts of actual warfare they are almost valueless. The lithographs of Charlet and Raffet are full of authority. Afterwards in France came the paintings of the Franco-Prussian War by Detaille, who is always rather cold, and by de Neuville-mere anecdotes. Of the studio-painted, and as regards detail, miniature-like paintings, of Meissonier, one agrees with Courbet (or was it Degas?) who said that everything is of steel excepting the cuirasses. It is most curious that such a military people as the French should have failed to get this enthusiasm for things military into their art.

The greatest possible credit is due the British and Canadian Governments, as well as to the Commonwealth of Australia, for the splendid manner in which they went about obtaining pictorial records of the war. They sent their best artists to the front and these artists covered all phases of the war in a most thoroughgoing and masterly fashion. France also had her official artists and like Great Britain and Canada is to have a permanent war museum of pictures. That the government of the United States did not realize the great importance of this work is certainly most regrettable and a serious reflection upon the vision and in telligence of those responsible. A few of our illustrators, it is true, were despatched to France to make a pictorial record of our military activities, but their drawings, for the most part, are rather commonplace. Alongside of the paintings and drawings by Sir William OrPen, Mr. Nevinson, Messrs. John and Paul Nash, the drawings by Messrs. Bone and McBey, the paintings by Sir JoHN LAVERY and all the rest of the able works executed for the British and Canadian Governments, they appear very feeble, indeed. Why were not such of our painters as Messrs. 
Childe Hassam, Sargent, Grorge Luks, Grorge Bellows, William J. GlackENS, GifFord BeAL and Rockwell Kent in France recording the life of our men and their part in the great conflict? And Mr. JоHN C. JoHANSEN to paint the great docks and railway systems built by the Engineer Corps? It was the purpose of the War Department not to send painters, but illustrators who had the capacity for recording impres. sions and whose work was suitable for reproduction in the press. This was a mistake. Even as drawings suitable for publication in the press the pictures were not a success, as is shown by the fact that out of one hundred and ninety-six drawings offered to the magazines only fifty-one were accepted for publication.

Why was not Lieutenant-Commander HeNRy Reuterdahl with our overseas fleet? And Mr. Paul Dougherty, the famous marine painter, both of whom undoubtedly would have painted some stirring pictures of the dangers and tragedies and heroism attending those who fought the cowardly monsters which infested the deep?

America has no pictorial record of the wonderful achievements of her navy during the Great War. It was the same in the Spanish-American War, of which there is not a single record of the navy's many achievements, some of them of a spectacular nature. Every foreign coun' try knew the value of propaganda and made particular efforts to tell their people what their working forces were doing. Our Navy Department has recorded nothing at all. It looks very much as if the authorities wished to keep the work of the navy anonymous.

Admiral Sims and the chairman of the Committee on Public Infor. mation both made strong recommendations to the Navy Department that Lieutenant-Commander ReUTERDAHL be sent abroad to depict the activities of our fleet. As a matter of fact, he entered the navy for this express purpose. Admiral Sims knew of Lieutenant-Commander ReUTERDAHL's long association with the navy and of his ability to portray her achievements. He also, doubtless, realized what an inspiration to the youth of the land a series of paintings by this artist would be if hung [24] 
in the Naval Academy at Annapolis. The Secretary of the Navy, however, apparently thought otherwise. It makes one sad to consider this amazing situation.

Why, too, has our government no plans for a museum in which to house pictorial records of the war? Even Australia has done this. The National Museum at Washington has made a collection of posters, but that is all. Possibly the drawings made by our official artists may also be deposited there, but even this is undecided.

Credit is due to the Library of Congress for their foresight in assembling a large and representative collection of posters and cartoons on the war. In this collection are posters issued by the American Government for recruiting, relief and for the special purposes of the Departments of Agriculture, Commerce, Labor, State, Navy, Treasury and War, many hundreds in number. Included also are the posters issued by the Food Administration, the War Finance Committee and many other organizations. Very comprehensive collections of broadsides, posters, cartoons and lithographs from Great Britain, Canada and France have also been made, as well as smaller ones from Italy, Germany, Poland and Russia. Many special exhibitions have been shown, including the cartoons of M. RAEMAEKERs, the lithographs of M. LuCIEN JonAs, the set of lithographs depicting Great Britain's efforts and ideals, and various posters and medals. Mr. Charles Moore, chairman of the National Commission of Fine Arts, had much to do with the collecting of this material. It is also a pleasure to note that the New York Public Library has formed a splendid collection of about two thousand war posters, very comprehensive in its scope.

A word here regarding the influence of the war on the various art museums of the country may not be out of place. No museum in the country rendered such a notable service to the community as the Art Institute of Chicago, where the attendance was much larger than during peace times; one million, one hundred and thirty-two thousand persons visited theirgalleries during I9I8. One hundred and twenty-six 
war meetings of various kinds were held within the building, numerous exhibitions during the course of the war helped to give an understanding as to what was taking place in Europe, students and instructors in the Art School gave much of their time to the making of posters, the Middle West Department of the Division of Pictorial Publicity was organized at the Art Institute, whose steps were a scene of almost daily meetings and where thousands of people met in connection with various "drives." A notable collection of the best of the war posters was made by the Institute; it coöperated with the government in every possible way in helping to win the war. This alliance of art with the state and the people, which finds its most perfect expression in France, should be continued, for art is not exclusively for the connoisseur. That the director of the Metropolitan Museum of Art took a firm stand against art connected with the war entering the portals of this institution will always arouse curiosity. The attendance at the Metropolitan Museum of Art in I918 was only a little more than half that of the Art Institute of Chicago - and the population of New York is about double that of Chicago.

Great credit is due Mr. John W. Beatty for his enterprise in obtaining many of the chief exhibits contained in the Allied War Salon which was held in New York in December, I9I8, for the Carnegie Institute of Pittsburgh, of which he is the Director of Fine Arts. It is a pleasure also to pay a tribute to the admirable work done by Mr. Duncan Phillips in agitating the value of art to the government in the prosecution of the war, for his work in helping to get up the Allied War Salon and for his coöperation with the American Federation of Arts in arranging numerous exhibitions of war pictures, which were shown throughout the country. In addition to arranging these ambulant exhibitions, which did much to stimulate patriotism throughout the country, the American Federation of Arts organized a strong committee on war memorials, of which the Honorable William $\mathrm{H}$. Taft is honorary chairman, Mr. Charles Moore is chairman and Mr. Robert W. de Forest is vice- 
chairman. Miss Leila Mechlin, the secretary of the Federation, who was very active in arranging the exhibitions of war pictures, is secretary of this committee. In the first chapter of my book I have noted the admirable work done by Mr. Charles Dana Gibson and Mr. F. D. Casey in organizing the poster artists of the country.

At about the time that this book is to go to press there comes the announcement that the newly formed National Arts Committee has senta number of portrait painters to Paris to paint many of the military and civil leaders of the Great War. This is indeed good news. The American Peace Commissioners have endorsed the project, of which Mr. Henry White is acting as honorary chairman.

This group of portraits, which is to be presented to the nation and deposited in the new National Portrait Gallery in Washington, is being painted by Messrs. Joseph De Camp, Edmund C. Tarbell, John C. Johansen, Douglas Volk, Irving R. Wiles, Charles S. Hopkinson, Miss Cecilta Beaux and Jean McLane [Mrs. John C. Johansen]. Mr. JosEPH DE CAMP is painting the Peace Table.

Mr. Herbert L. Pratt is secretary and treasurer of the National Arts Committee, which includes in its membership Messrs. J. P. Morgan, Henry C. Frick, Robert W. de Forest and Mrs. E. H. Harriman. Patriotic citizens in various cities besides New York have also contributed towards the expenses of this undertaking.

A few days previous to the announcement of the National Arts Com. mittee [29th May, 1919] the following letter was sent by the writer to the President of the United States, acting on behalf of a number of artists and persons interested in art:

"A group of Americans who realized the importance of art as a national asset, and who are deeply stirred by the example of Great Britain, France, Canada, Italy and Australia in sending their best artists to the front to create permanent and national records of the war, its heroism, sacrifice and suffering, have deputed me to send you this letter. 
We deplore the fact that thus far very little has been done to bring before present and future generations of Americans the great and inspiring part our country played in the war. We urge that a number of our leading artists be sent abroad immediately to paint from actual observation our historic battlefields, portraits of our army and navy leaders, of our soldiers, the life of our Army of Occupation on the Rhine, the scenes of war, the stupendous results of our efforts in engineering, railway building, hospital equipment, shipping and all other branches of our war activity.

We also regret deeply that we have missed the opportunity of gaining the services of our greatest painter, SARGENT, who has just painted for the British Government a monumental war canvas.

It may be too late to paint incidents of warfare, but modern war consists not merely of fighting. There are still immense fields to be covered if immediate action be taken. We appeal to you, therefore, for approval of such a project. The inspiring Canadian example proves that a national memorial of this kind can be created without the financial, though not without the moral and practical support of the government. The success of such a project would mean the presentation to our government of the finest kind of a war memorial."

At my suggestion the National Arts Committee agreed, upon certain conditions, to broaden the scope of its activities and to have at least a few pictures painted of the description that I suggested in my letter to the President. Unfortunately, however, I was unable to bring this about. 


. 
UNITED STATES OF AMERICA 


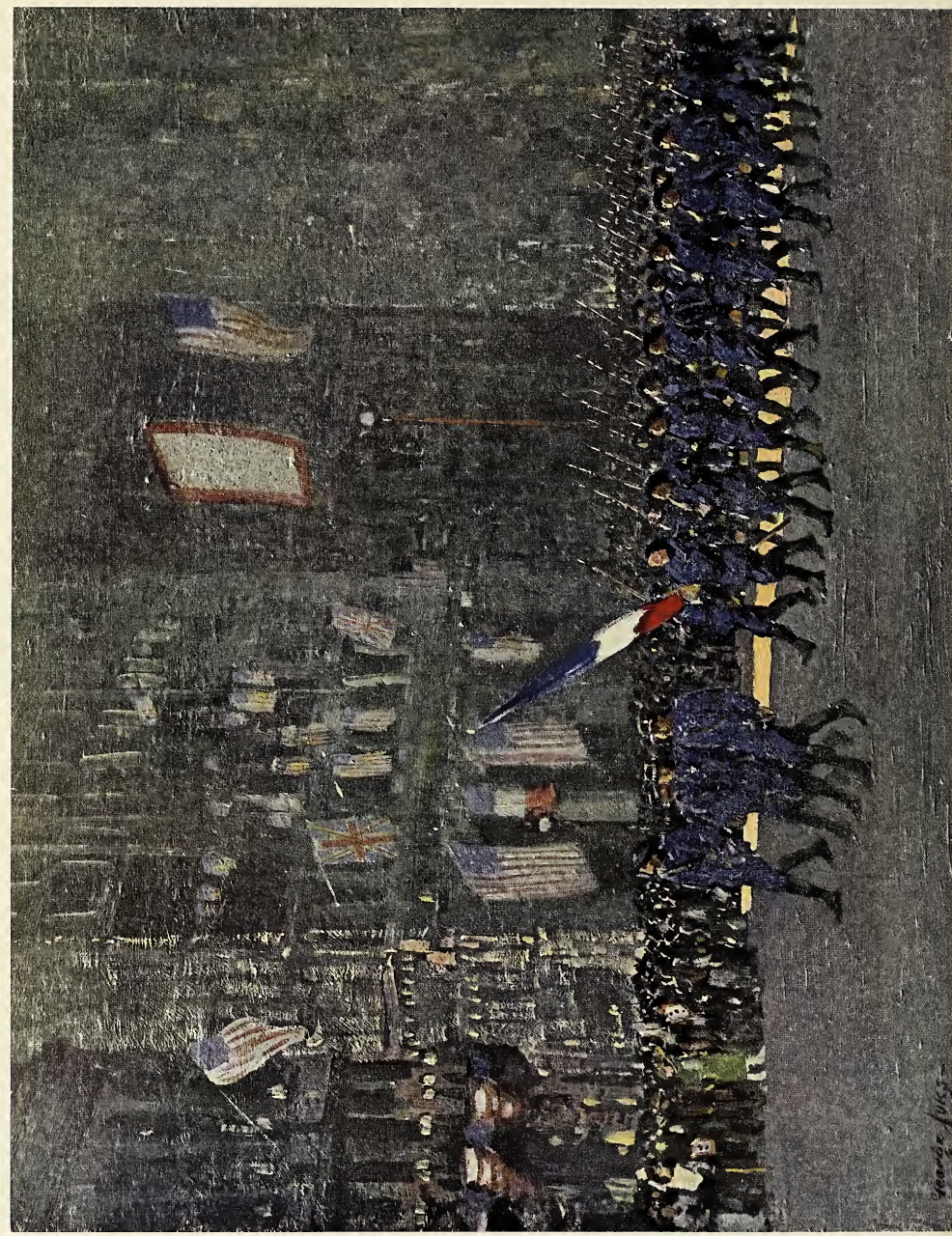




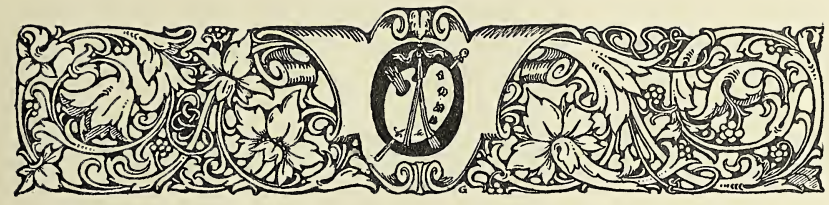

\section{ART AND THE GREAT WAR}

CHAPTER ONE

\section{THE UNITED STATES OF AMERICA}

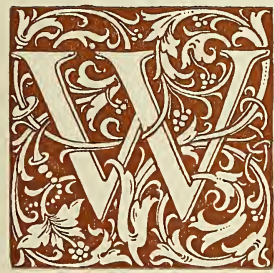

ITH reference to the inspiring opportunity given to the painters, sculptors, illustrators and cartoonists of the country by the war, one critic has written: "Never since the Middle Ages, when the church taught its lessons by means of pictures to people who could not read the written word, has art been called upon to serve in so many ways." It is gratifying to know that the artists of America came forward with an eagerness to serve the country that was not excelled by any other group. More than that, all of the drawings and posters which they made for the government were presented, as gifts. It is a pleasure to pay a tribute to the splendid spirit of patriotism shown by these men.

The Division of Pictorial Publicity of the Committee on Public Information, of which committee Mr. George Creel was chairman and the Secretary of State, the Secretary of War and the Secretary of the Navy were members, was established shortly after America's entrance into the Great War. This was done at the urgent request of Mr.CHARLEs Dana Grbson and a body of American illustrators. Mr. Gibson was 
chosen to be chairman of the Division of Pictorial Publicity; his associates were Mr. F. D. Casey, who was vice-chairman, and Messrs. F. G. Cooper, Charles B. Falls, Louis Fancher, Henry Reuterdahl, C. D. Williams and Robert J. Wildhack.

The function of the Division of Pictorial Publicity consisted in supply ing the various departments, bureaus and commissions of the government with every form of pictorial publicity that they desired. Membership in it was unlimited; any individual who expressed a desire to carry out such work as was required by the government automatically became a member.

The headquarters of the Division were at 200 Fifth Avenue, New York, with sectional branches in Chicago, Boston and San Francisco. The New York division met once a week, at which meetings requests from the government for various designs were read. The drawings submitted were passed upon by the chairman and his associates and then sent to Washington for final approval. That the officials in Washing ton had the privilege of selecting the designs, instead of the artists, was of course most unfortunate. This most unfair system accounted for the issuing of several thoroughly inartistic Liberty Loan posters-the choice of the Treasury officials.

From its inception on 17 th April, 1917, until the I 5 th of November, 1918, the Division of Pictorial Publicity made for the government and various patriotic societies and committees, fifty-eight in number, seven hundred posters, two hundred and eighty-seven cartoons and four hundred and thirty two cards and designs for newspaper advertising. Besides the various departments of the government, these designs were used by such organizations as the Red Cross, the Shipping Board, the American Library Association, the Y.M. C.A., the Y.W.C.A. and the Salvation Army. 
As a matter of record, the names of the associate chairmen and the executive committee are here appended:

\author{
Associate Chairmen \\ FRANCIS C. JONES \\ ARTHUR F. MATHEWS \\ JOSEPH PENNELL \\ EDMUND C. TARBELL \\ DOUGLAS VOLK
}

HERBERT ADAMS

E. H. BLASHFIELD

RALPH CLARKSON

CASS GILBERT

OLIVER D. GROVER

\title{
Executive Committee
}

F. G. COOPER

N. POUSETTE-DART

I. DOSKOW

F. E. DAYTON

C. B. FALIS

A. E. GALLATIN

RAY GREENLEAF

MALVINA HOFFMAN
W. A. ROGERS

HENRY REUTERDAHL

JACK SHERIDAN

H. SCOTT TRAIN

H. D. WELSH

J. THOMSON WILLING

H. T. WEBSTER

WALTER WHITEHEAD

\section{I}

Owing to the efforts of the Division of Pictorial Publicity, the posters issued by our government in time became very creditable. In the beginning of the war our posters were extremely crude and inartistic and consequently made but a small appeal. This was owing to the fact that the various departments of the government, with an appalling ignorance of all things artistic, merely gave orders to commercial firms of lithographers to turn out posters and other forms of pictorial publicity, without thought of the artists at all.

Innumerable posters were required by the government for Liberty Loan, War Savings Stamp, Red Cross and other "drives," for recruiting purposes, to urge the conservation of certain foods, as well as coal, to speed up shipbuilding and for dozens of other purposes. An anonymous author has written: "To build morale, to spiritually awaken the nation, 
to stimulate concentrated effort, to quicken every war activity, the government employed art in the form of pictorial publicity for the first time and on a grand scale. This campaign may be described as 'The Battle of the Fences."

The artists went to the government and offered their services, and without recompense, and it was only after considerable opposition that their services were accepted.

The best men in the country were mobilized by Mr. Grisson's and Mr. Casey's committee, and considering that we had but few real poster artists in this country, owing to the fact that technical schools in America are almost non-existent, the results obtained by many of these men were excellent.

Twenty years ago the artistic poster enjoyed a wide vogue in Great Britain, in France and in this country. Many elaborate books were issued on the subject, magazines devoted to posters were published, large exhibitions were arranged, and hundreds of collections were formed. Then the interest in posters died out. But many of these lithographs will always hold an honorable place in the portfolios of the amateur and the museum. In France the lithographs used for advertising purposes which were drawn by Toulouse-Lautrec and M.Steinlen rank among the most notable graphic work of their time. Cheret, Mucha and Grasset also produced work which will live. In England notable work was done by Mr. William Nicholson, Mr. James Pryde and Aubrey Beardsley, while many extremely fine posters were executed in America, notably by Messrs. Maxfield Parrish and Edward Penfield. Then the Great War came along and with it the renaissance of the poster. Once more, as in the Middle Ages, art became the property of the people, as it should be, and not ticketed specimens in a tomb-like museum.

The effective poster is the simple poster, and one that tells its story in unmistakable terms. It must, too, have been drawn by a master craftsman, one with a knowledge of design, a proper feeling for color and power of conception. It is because possessed of those qualities that 
the Books Wanted poster of Mr.C. B. Falls ranks with the best of our war posters. Mr. Falls designed several other excellent posters, including three entitled The Camp Library is Yours, New York Decorators' Fund, and E-E-E-Yah-Yip.

On the whole, I should say that the most notable series of posters de, signed by one man in America are those of Mr. Adolph Treidler. All of his lithographs are conceived and drawn in exactly the manner true posters should be made. The poorly drawn sketches by Messrs. HowARd ChANDLER CHRISTY and HARRISON Fisher and others of our popular illustrators, were not posters at all. Neither was the altogether absurd Greatest Mother in the World "poster." It is possible, of course, that such designs as these appealed to certain intellects, and thereby served their purpose. Among Mr. TreIDLER's many very successful posters may be singled out his twenty-four sheet lithograph urging the purchasing of war savings stamps, which shows a gun in action, Have You Bought Your Bond? Help Stop This, Farm to Win and Make Every Minute Count for Pershing.

None of our posters have been more thoroughly artistic than those drawn by Mr. W. T. BendA. His posters, in color, issued to stimulate recruiting among the Poles in this country, are very handsome compositions; his simpler drawings, such as that made for the Y.W.C A., entitled Stand Behind the Country's Girlhood, are charming and strong drawings.

Mr. Henry Raleigh, with his Hunger, Blood or Bread, and Halt the Hun posters produced three of the best of our war posters, drawings full of strength and character. The poster entitled Keep it Coming, by Mr. George Illian, was also a notably fine drawing, as was Mr. Wallace Morgan's Feed a Fighter. Mr. Joseph Pennell's statue of liberty poster was also excellent, as were two others by him, of shipping subjects, enlargements of his lithographs.

Effective posters were also drawn by Messrs. Henry Reuterdaht, Edward Penfield, Charles Livingston Bull, Charles Dana Gibson, [37] 
Albert Sterner, F. Walter Taylor, Fred J. Hoertz, Walter H. Everett, George Wright, Hibbard V. B. Kinne, Jonas Lie, F. Luis Mora, Howard Giles, W. D. Stevens, Charles Sarka, H. Devitt WELSH and several other artists. Mr. WELSH, it may be mentioned, was Art Director of the Committee on Public Information during the autumn of I9I7.

For the Victory Liberty Loan, Mr. L. A. Shafer designed an excellent poster, showing an American destroyer coming to the rescue of a transport, about to be torpedoed.

The navy had its own organization for pictorial publicity, conducted by the United States Navy Recruiting Bureau, in New York. During the entire war Lieutenant-Commander HENRY ReUTERdahl served as artistic advisor. Many of the navy's most striking and successful draw. ings and paintings used for recruiting purposes were executed by him.

It is worth noting that the navy was the first department of the gov, ernment to issue any posters. Lieutenant-Commander REUTERDAHL was attached to the United States Navy Recruiting Bureau in March, I9I7, and atonce set about getting good posters for the navy. Acting as a committee of one, he wrote to about fifty of our prominent artists asking for poster designs, and a few days before this country entered the war the navy actually had some of their first posters on the lithographic stone. Thanks to the foresight of Lieutenant-Commander Reuterdaht, the navy, as usual, was ready.

The marine corps also acted independently, but, like the navy, obtained their posters from the same artists who contributed to the Division of Pictorial Publicity. A number of excellent posters were also issued by the Publications Section of the United States Shipping Board Emergency Fleet Corporation, for display in shipyards and industrial plants. These posters had the desired effect of making many thousands of workmen feel the patriotic necessity of close coöperation with the government and in speeding up their work.

It is interesting to note that Mr. BRANGWYN and M. RAEMAEKERs both [38] 
made designs for use by the United States Navy. Excellent ones were also drawn by Messrs. Albert Sterner, George Wright and James Daugherty. For a hoarding in Chicago, Mr. Robert Reid painted a picture measuring fifty by one hundred and thirty three feet. LieutenantCommander ReuTERDAHL made three paintings of large dimensions to advertise the Fourth Liberty Loan; these were shown in Washington. In collaboration with Mr. N.C. WYETH, he painted a picture ninety feet long and twenty five feet high, for the Third Liberty Loan, which was placed on the Sub-Treasury Building in New York.

\section{III}

It was in May, I9I7, that plans were set on foot to send artists to France to make a pictorial record of the various activities of our armies. Major Kendall Banning, who was at that time director of the Division of Pictures of the Committee on Public Information, and who afterwards was attached to the War College Division of the War Department, was responsible for this recommendation. He at once consulted with representatives of Great Britain and France and learned what those countries had done in using their artists for portraying the histories of their armies. Their advice was to commission capable artists and to assign them to duty within military zones, which would not be open to civilians.

In June, 1917 , Major Banning got in touch with many artists who seemed to him to be available for duty as official artists; Major Banning also conferred with Mr. Charles Dana Gibson. Major Banning then submitted his recommendations to the Secretary of War. It was, how, ever, not until late in January, I9I8, that the Secretary of War took any action. Authority was then obtained to commission eight men as offcial artists in the Engineer Reserve Corps. At Major Banning's suggestion, Mr. Charles Dana Gibson was chosen chairman of a group of artists to make recommendations. Mr.J. ANDRÉ SMITH was the first of the group to be commissioned a captain in the Engineer Reserve Corps 
and sent overseas. He was followed by Captains Ernest Peixotto, William J. Aylward, Harry Townsend, Wallace Morgan, Grorge Harding, Walter J. Duncan and Harvey Dunn.

Up to January I4, I919, two hundred and seventy-seven drawings had been received from our overseas artists, one hundred and five being from Captain J. André Smitr. At the Allied War Salon, held in New York, in December, 1918, all of the drawings received to date were exhibited, one hundred and ninety-six in number. These drawings had been shown in Washington the month before and in January, I9I9, they were exhibited in Pittsburgh, afterwards being shown in other cities.

Considering the fact that these artists were rather hampered in their work, it is most creditable to them that they produced so many good drawings; it should also be borne in mind that they were depicting very unfamiliar subjects. The collection on the whole reflects the spirit of our men, their backgrounds and the incidents of their lives in a reasonably satisfactory manner, although it leaves much to be desired. Certainly they are more valuable than any photographs. The subjects of these drawings were thus described by the art critic of the New York Times: "The subjects cover practically the whole field of war, dressing stations, supply trains, bomb-proof billets, 'chow,' officers' mess, German prisoners, the hurry call to fight, and the roll-call afterwards, artillery and machine guns, drawings showing the kind of ground over which our men fought, the type of village in which they were billeted, the cavalry school at Saumur, machine gun battalions at drill, and a hundred other scenes of activity, all of which give a clear impression of the great powers of organization at work behind them."

The pencil sketches on tinted paper, touched with water-color, by Captain J. ANDRÉ Smith, are excellent drawings. His subjects are principally landscapes and towns, and strictly speaking are not war draw. ings at all. Extremely well drawn are also his pastels and water-colors.

Captain George Harding's pastels of marching soldiers and scenes right at the front are also well drawn and very graphic. Captain ERNEST [40] 
Pвixотто's sketches of landscapes, men on the march, locomotive shops, and other subjects, which are executed in charcoal and gray water-color, are also of interest.

Captain Wallace Morgan's excellent draughtsmanship was well illustrated in his spirited drawings, which were among the best sent home by these artists.

Unfortunately Captain HARvey Duns's sketches did not arrive in time to be shown with the drawings of the other official artists. Appar. ently he made very few drawings, but those he did make are excellent, if one may judge from the photographs of them which he has showed me. Captain DunN, with two or three of the other artists, actually went over the top with the men. Rapid sketches made by him on a specially designed box, with rollers to wind up his sketches and present a new surface of paper, possess a very real interest.

\section{IV}

Several artists went to France who did not hold official positions. One of these was Mr. SAMUEL J. Woolf, who went ostensibly as a war correspondent, but really with the idea of making drawings and paint. ings. With him he carried letters from the War Department and the Secretary of the Navy; accordingly, he not only secured permission to visit the training camps, but also the various sectors held by the American troops. He lived with our men, eating and sleeping with them; at one time he drove an ambulance, at another acted as cook. He was slight. ly wounded and also gassed. All of these experiences saturated him with his subject and enabled him to produce a series of paintings and draw. ings of decided interest. Several of Mr. WooLF's paintings and drawings were shown at the Allied War Salon in New York; twenty-one paintings by him and about sixty sketches and drawings formed a special exhibition held in New York in February, 1919.

Mr. Lester G. Hornby was with the American troops during the summer and autumn of 1918 and made a number of slight, but interest- 
ing, drawings. Some of these sketches were published in the spring, I9I9, issues of Harper's Magazine to accompany a series of articles entitled How the War Was Won, written by General Malleterre of the French army. Mr. HornBy was given passes as a sketch-correspondent by the French Committee on Public Information.

Mr. WiLl Foster, who was in the army at the beginning of the war, and later became a member of the ambulance service, made a number of admirable drawings at the front. Several of his drawings were reproduced in the April, 1919, issue of Scribner's Magazine to accompany an article written by the artist, entitled A Day with a Sketch-block at the Front.

Mr. Jo Davidson, the sculptor, went to France, where he modeled excellent busts of many of the great allied generals and statesmen; $\mathrm{Mr}$. Robert I. Aitken also did some work of this nature. Mr. Joseph Cum mIngs CHASE went to France to paint the portraits of various American and allied officers, as well as privates who had been decorated. His portraits are devoid of merit. Three etchings of Rheims Cathedral under fire were made by Mr. Louis ORR, three plates of marked excellence.

\section{$\mathrm{V}$}

Mr. Joseph Penneli has made a hundred or more lithographs of war work in America, a continuation of a series started in England. They form a part of his set of lithographs dealing with the wonder of work. Building the Battleship, Shell Factory, Shaping a Gun from an Ingot, and Making War Locomotives are titles of drawings which suggest the range of his subjects. In his Food and Fuel series we find such titles as Loading Coal, Stock Yard and The Mining Town. These lithographs constitute an adequate and excellent record of America's manifold preparations for waging war. I know of no one who could have done the work better. For Mr. PenNell's album of reproductions of his war work in England, Mr. H. G. Wells wrote an introduction in which he stated that "Through all these lithographs runs one present motif, the motif 
of the supreme effort of Western civilization to save itself and the world from the dominance of the reactionary German Imperialism that has seized the weapons and resources of modern science."

Mr. Vernon Howe BAILey has also made an excellent series of draw, ings and lithographs of war work in America, remarkable for their sound draughtsmanship and sense of verity. Seventy-six of these have been exhibited in many parts of the country, under the following classifications: Navy Yards, The Fleet, Gun Shops, Bethlehem, Aeroplanes and Merchant Ships. Mr. BAILEY executed his drawings at the New York, Philadelphia, Washington and Norfolk Navy Yards, at the Bethlehem Steel Company's Works, the Curtis Aeroplane Company's Works, at the Mineola Flying Field and at three different shipyards. Aside from Mr. BAILEY's beauty of drawing, his studies possess a very real historical value.

Mr.John C.Johansen went to the shipyards and painted a very notable set of thirty or more pictures which will always be a valuable record of this most necessary of all war activities in the United States. They are very well painted. Some of these pictures show us ships under construction, while several are of launchings. A number of shipyard pictures were also painted by Mr. Thornton OAKLEY, while several excellent lithographs were drawn by Mr. Herbert Pullinger and noteworthy drawings were made by Mr. Hugh FerRIss, of similar subjects. Unfor' tunately but few records were made of the camps in this country, but the navy fared a little better. Mr. GeORGE Wright sketched at the Pelham Bay Training Station and the Brooklyn Navy Yard and Lieutenant-Commander Henry Reuterdahl made many colorful paintings of our destroyers and other naval craft in home waters.

\section{VI}

Innumerable pictures have been "turned out" by the painters of this country to be used for patriotic purposes. These battle pictures, atroc, ity pictures and pictures of hospital ships being torpedoed by subma- 
rines, all painted in America, were used in connection with the Liberty Loan and Red Cross "drives." The generous and patriotic spirit shown by these artists was admirable and their pictures served their purpose well by encouraging the public to buy bonds and in obtaining contributions. But, as one writer has truthfully said, "Art cannot be hurried. Art should not be hustled into serving an immediate and clamoring cause. Art is feeling, and feeling is born within the artist." As I have said, these pictures served their purpose, but they have no documentary value and only a very few can possibly be considered works of art, and as possessing aesthetic qualities, and it does not seem to methat these pictures should be seriously considered in a book of this nature. In this generalization I do not include Mr. George BeLlows's Murder of Edith Cavell, which in composition and color is quite impressive.Very well painted, also, is Mr. Paul Dougherty's picture entitled Sunk Without a Trace.

There are, however, a number of exceptions to the above assertion or rather there are number of pictures which were painted in this country which do not fall into the above category. I refer to the pictures of actual events in the United States and to pictures of a symbolical or allegorical nature.

Mr. George Luks painted a picture of the famous French "Blue Dev. ils" marching down Fifth Avenue, which is one of the best of all the American war pictures. It is admirably painted, rich in color, and full of life and vigor; the suggested motion of the men as they swing down the avenue is really quite masterly. Less interesting in every way, but also a notable picture, is another canvas by Mr. Luks entitled CzechoSlovaks in American Camp Celebrating Their Recognition as a Nation, in which they are seen dancing around a huge bonfire, which shoots an enormous yellow flame skywards. Yet another painting by Mr. Luks, of the celebration held in New York upon the signing of the armistice, is really more of an enormous, loosely constructed sketch, but at the same time it is full of movement and fire and is highly amusing. Well 
painted, also, is Mr. Luks's picture which shows the Leviathan steaming up New York Bay, freighted down with members of the returning Twenty-seventh Division and escorted by scout patrols and various other craft. It is a matter of keen regret that other artists did not essay such subjects as these.

Mr. GrFford Beal painted a picture of the peace celebration in New York, a canvas full of rich color, and Mr. HaYley LeVer one of French Day on Fifth Avenue. A series of paintings showing New York bedecked with the flags of the United States and the Allies was painted by Mr. ChILde Hassam - a very notable set of pictures by one of the greatest of living American artists. No artist has equalled Mr. Chinde HAssAm in recording the beauty of New York, and it was fortunate that New York had such an artist to paint her bannered beauty. Mr. HassAM is the foremost exponent of the teachings of Impressionism in America, a most individual and original painter and one possessed of an extremely sensitive color vision. The freshness and coolness of his pigments are seen to great advantage in these pictures of New York on parade. My only criticism is that in none of them does there appear among the crowds a soldier or a sailor. This would have given a certain note, a certain touch, an accent, which would have enhanced the picture, besides, of course, being truthful.

Mr. Edwin H. Blashrield's picture entitled Carry On is one of the most notable war pictures painted by an American artist. This canvas, by one of America's well-known mural painters, is full of fire and shows a spirit of ardent patriotism. It is remarkable both in design and color. Fortunately the Metropolitan Museum of Art opened its doors, barred to all art connected with the war, wide enough to admit this picture, which it has purchased. A painting by Mr. William Ritschel, called Crusaders, is another spirited and noble conception. Three paintings by Mr. Augustus Vincent TACK, entitled I9I8-CarryOn, To the Last Drop and You Must Choose, are distinguished by refinement of vision and exquisite color, his blues being particularly beautiful. Mr. Grorge 
BeLLows painted two excellent canvases symbolizing the dawn of peace for the Red Cross membership drive which was held in New York in December, I9I8, as did Mr. Maxfield Parrish. The other paintings, as well as numerous arches, made for this occasion were excruciatingly bad, being the work of half-baked extreme modernists.

In America lithography, the most autographic of the reproductive arts, is just beginning to receive from collectors the attention which it merits. Whistler's lithographs are very rapidly taking their place with his etchings in popular estimation and numerous American artists have been attracted to the artistic possibilities of the lithographic stone. Messrs. J. Alden Weir, John Sloan and Ernest Haskell have several stones to their credit, Mr. William J. Glackens one, Mr. Albert Sterner quite a number, and Mr. Joseph Pennell hundreds. Lithographs have also been drawn by Mr. George Bellows and Mr. Childe Hassam, of subjects connected with the war, and it is of these that I wish to say a few words.

Mr. Grorge Bellows has drawn a set of twelve lithographs depicting atrocities committed by the German armies in Belgium, based upon Lord Bryce's Report. His Murder of Edith Cavell, from which he subsequently made a painting, as he did from several others of the lithographs, is beautifully composed and beautifully drawn. Although theatrical in conception, it is on the whole a splendid piece of work. The titles of Mr. Bellows's other lithographs are Bacchanal, Sniped, Gott Strafe England, Belgium Farmyard, Massacre at Dinant, The Cigarette, The Germans Arrive, Dressing Station, The Barricade, The Last Victim and Return of the Useless. Some of these drawings are marred by rather feeble and faulty draughtsmanship, others in their terrible frankness exceed the bounds set by art and by taste, but these are only details: this set of lithographs is one of the most eloquent contributions made by an American artist. Although based on fact, these lithographs are not a record of personal experience, having been drawn in America. They should not, however, for this reason be lightly dismissed from serious 
consideration, because if they were, all of Rembrandt's paintings and etchings with Biblical subjects would have to go with them.

Years agoMr.Chinde Hassam made some delightful drawings in black and white of street scenes in Paris, London and New York. In returning to black and white I am glad that Mr. Hassam has chosen lithography as his vehicle. Mr. Hassam's six lithographs of New York seen in war time are entitled Lafayette Street, The Avenue of the Allies, Camouflage, The French Cruiser, North River and New York Bouquet. These rapid notations are all delightfully spontaneous and brilliant in execution.

\section{VII}

If never before had the poster artist enjoyed such a golden opportunity to make use of his art, this was equally true of the cartoonist. $\mathrm{He}$ wielded a powerful weapon and in his hand it could truly be said, as of the author, that the "pen is mightier than the sword."

The cartoonist proved to be one of the most important of all agencies for moulding public opinion. In America Mr. Chardes Dana Gibson played no small part in putting the real issues of the war before the public, and in a striking and telling manner. Mr. W. A. Rogers was another strong cartoonist, as was Mr. Cesare, Mr. Boardman Robinson, whose technique was borrowed from M. ForaIN and who technically is one of the most adroit of our cartoonists, also did some remarkably clever and telling work for Colonel George Harvey's War Weekly, in which it appeared anonymously. Many of the cartoons of Messrs. Rogers, Cesare and Robinson have been collected in album form.

\section{VIII}

Landscape, or designation targets, have long been used by the armies of Europe and in the training of the recruit they are of great value. These "targets" are large landscapes depicting typical French rural scenery and are used in our military schools to train the embryo artillery officer to locate quickly a given point in a landscape. The most satisfactory land- 
scape targets are those painted in clear and bright colors. The sine qua non is correct perspective. The sizes vary from three by six feet to five by twelve feet. These landscapes are used in class-room instruction to visualize the country in which the men are to fight, for panoramic sketching, for working out problems of offense and defense, for target designation according to the clock-face method in machine-gun, artillery and rifle practice, and for other purposes.

Many of our landscape artists supplied the need for these "targets" in our artillery schools and thereby rendered a very useful service to the government.

\section{IX}

The manner in which the sculptor was able to apply his special talents to work connected with the war, and the way the war reacted upon his art, forms an interesting feature of our study of the part art played in the Great War.

Many sculptors entered the camouflage unit of the army [40th Engineers], where they were able to render notable service. Others are now having an opportunity to design monuments to our heroic dead. Captains J. André Smith and Aymar Embury, 2nd, designed medals for the government, they being modeled by Private Gaetano Ceerere. Mr. PaUL Manship, the most gifted of living American medalists, coöperated with several noted artists on the new Congressional Medal of Honor for the navy and on the Distinguished Service Medal and Distinguished Service Cross for the navy. The latter two designs were accepted, but that for the Medal of Honor was rejected. The Secretary of the Navy then obtained designs from various manufacturing concerns, eventually accepting that submitted by a button maker. Comment is unnecessary. Mr. MANSHIP also modeled a Jeanne d'Arc medal of marked distinction, as well as three others which were sold for war charities; these were entitled Kultur, French Hero's Fund and Art War Relief.

An excellent opportunity to study what effect the war had on American sculpture was afforded at the Allied War Salon held in New York 
in December, 1918. Forty-three works were in the collection, the work of thirty-two sculptors. Nothing in this group possessed more vitality and showed greater mastery of modeling than Mr. MAHONRI Young's colored soldier on the march called One of the Buffaloes, which was the nickname given to one of the colored regiments. Also full of life was his Artilleryman. Clio Bracken [Mrs. H. H. Bracken] had an excellent statuette of Lieutenant Henri Farré, and other works of note were contributed by Mr. Herbert Adams, Mr. Solon Borglum, Miss Malvina Hoffman, Mr. Hermon A. MacNeil, Mr. Isidore Konti, Anna Coleman Ladd [Mrs. Maynard Ladd], Miss Jessie M. Lawson and Mr. Theodore SPICER-Simpson.

In England Captain Derwent Wood did some notable work in constructing masks to cover facial injuries. Professor Henry Tonks also worked with the plastic surgeon. A Boston sculptress, Anna ColeMAN LADD [Mrs. MAYNARD LADD], reading reports of Captain WoOD's studies, went to Paris, where she and her assistants rendered splendid service in the French hospitals making new faces for soldiers whose faces had been partially shot away.

\section{$\mathrm{X}$}

Under the direction of Major Evarts Tracy, an architect, a camouflage unit for our army was organized in August, 1917. The men studied at the American University, Washington, D.C. This unit formed a part of the Corps of Engineers [40th]. It was a military organization composed of artists, architects, carpenters, ornamental iron workers, tinsmiths, plasterers, photographers, stage carpenters and property men. Lieutenant-Colonel Bennion commanded the camouflage unit in France.

The work in general dealt with the concealment of gunemplacements, trenches and sheds of military value; the screening of roads and manufacture of materials for this purpose; the painting of roofs and large areas of canvas for the covering of ammunition storage and the like; the making of various devices and clothing for the concealment of observers and snipers and occasionally the painting of a scenic drop. 
Captain Homer SaINT Gaudens, who was in charge of the work of the Second Army, informs us that camouflage had two functions, to deceive the eye and to deceive the aeroplane cameras; aeroplane obser. vation was largely photographic. Concealment from aeroplane observation he states was the more difficult, as the camera was more accurate than the eye. Color, Captain SaINT GAudens further informs us, proved to be of relatively small importance, but that strips of dull-colored cloth, tied to fish-nets gave the needed variation of lighı and shade.

Modern camouflage is based upon the studies of Messrs. Abbott Thayer and Louis Fuertes, two painters, as well as those of Dr. Chapman of the American Museum of Natural History, who have made a study of bird life and protective coloration. Some familiar examples of nature's camouflage are the frog spotted like a tree; the polar bear with a coat of white fur which blends with his surroundings of ice and snow, and the tiger, striped in such a way as to make him invisible in a bam. boo forest.

An interesting collection of sketches made by the overseas men of the camouflage unit was shown at the Arts Club of Washington in April, 1919. Portrait studies were exhibited, as well as drawings show. ing fortifications and military works.

\section{$\mathrm{XI}$}

Owing to Germany's development of the submarine and the large number of them which she was able to operate, marine camouflage became a most important science.

In this country Mr. William ANDrew Mackay, an artist, was the pioneer marine camoufleur. He began his studies in 1912 and in 1914 worked with the Navy Department. Some months before the United States entered the war Mr. Mackay founded a school for the study of marine camouflage and when we finally entered the conflict the group of men under him became the nucleus from which the great body of men in this service grew.

Marine camouflage was done under the direction of the Navy De[50] 
partment, the work being executed by the United States Shipping Board Emergency Fleet Corporation's department of camouflage. In each district was stationed a district camoufleur, with a corps of trained men.

The first system of marine camouflage to be used was intended to make the vessel as nearly invisible as possible. Mr. R. F. Yates, in the course of a most interesting paper on the subject, says that in this system "the colors used are of such combinations and values that they cause the vessel to melt away on the horizon."

This system, an attempt to make vessels invisible, was later largely superseded by a system of "baffle" or "dazzle" painting, which was invented by Lieutenant-Commander Norman WILkINson of the British navy, a well-known marine painter. His painting was designed to distort the outlines of the ship and mislead the submarine commander as to the craft's size and character, as well as to the course she was making. This system was most successful and undoubtedly prevented many fine ships from being sent to the bottom of the sea.

\section{XII}

A committee on Arts and Decoration, a sub-committee of the Mayor's Committee on National Defense for the City of New York, was established in May, I9I8. The director invited the present writer to organize this committee and to accept the chairmanship of it. This committee was organized for the purpose of developing the field of art in connection with the war, where the services of artists, architects, sculptors and those practising the allied arts were employed.

A Bureau of Information was established, in the Hall of Records, to advise and direct those seeking to apply their talents to work connected with the war. Here could be obtained accurate information concerning the designing of pictorial placards for government purposes, cartoons, landscape targets, military and naval camouflage, decorations and other subjects. A leaflet containing suggestions and information was prepared and distributed gratuitously.

A Division of Exhibitions was established to further the cause of $[5 \mathrm{I}]$ 
pictorial propaganda. Three times the official British lithographs reflecting Britain's efforts and ideals in the Great War were shown under the auspices of this committee, and a collection of one hundred and twenty five colored facsimiles of cartoons by M. RAEMAEKERS was shown in the various cantonments throughout the country. It was the chairman of this committee, coöperating with Messrs. Duncan Phillips and $\mathrm{Au}$. GUSTUS Vincent TACK, whom he appointed to form the Division of Ex hibitions, who arranged the Allied War Salon held in New York in December, 1918.

The Committee on Arts and Decoration assisted in the artistic censoring of the historic floats, banners and costumes appearing in the In dependence Day Pageant-Parade held in New York in 1918.This parade, in which about sixty different nationalities took part, was easily the most interesting parade ever held in New York. The Advisory Art Committee of the Liberty Loan Committee asked for the closest coöperation between the two committees. The chairman of the Committee on Arts and Decoration was also invited to serve on the Victory Arch Committee. These are but a few examples of the wide and useful scope of this committee in coördinating art work in so far as it affected the community.

Mr. Duncan Phillips, a member of this committee, drew up a set of resolutions containing a suggestion whereby Germany and Austria might be compelled to make at least some reparation for their wanton destruction of works of art in France, Belgium and Italy. This resolution was sent to the President of the United States. The last clause in it read as follows: "Resolved, that we do herewith petition our people's repre" sentatives, the President of the United States, and others who may be vested by him with authority, to suggest to the representatives of the allied nations when they assemble in council and consider upon what terms Germany and Austria may obtain peace, that an Inter-Allied Commission of Artists be empowered to select such works of art as will be demanded from the German and Austrian Governments, not in revenge, but in justice, as part of our war indemnity, and as partial reparation 
for those beautiful cathedrals and other monuments which the forces of evil in Germany and Austria have deliberately caused to be desecrated and destroyed."

Mr. Lloyd Warren was the vice-chairman of this committee, and the executive committee was composed of Messrs. Herbert Adams, Paul W. Bartlett, Nicholas Murray Butler, Robert W. de Forest, Charles Dana Grbson, Thomas Hastings, Archer M. Huntington and Clarence H. Mackay. Thirty-four men composed the general committee.

\section{XIII}

The Liberty Loan Committee in New York had a very competent Art Advisory Committee which rendered a most useful service in assisting in their campaigns. Mr. H. Van Buren Magonigle was chairman of this sub-committee, his associates being Messrs. Herbert Adams, Paul W. Bartlett, Edwin H. Blashifield and Charles Dana Gibson. Their appointments were made when the arrangements for the Fourth Liberty Loan were already under way and therefore, in view of this, the committee decided to concentrate their efforts upon the decoration of Fifth Avenue, Mr. J. Monroe Hewlett being placed in charge.

Thanks to the work of this committee, New York had during October, I9I8, the opportunity of viewing one of the most inspiring exhibitions of pictures ever held in the metropolis. Fifth Avenue, the fairest avenue in the world, was the gallery, about a hundred windows along the thoroughfare being the settings for the paintings. Many of the foremost artists in the country painted these patriotic pictures, including Messrs. Paul Dougherty, Gari Melchers, Edwin H. Blashfield, Augustus Vincent Tack, Frank W. Benson, George Bellows, Jonas Lie, Gifford Beal and George Luks. Messrs. Herbert Adams and Mahonri Young were among the sculptors. This most interesting display was the idea of Mr. Augustus VInCENT TACK, who carried it out with marked success. The idea involved in this exhibition is contained in the an nouncement drawn up by $\mathrm{Mr}$. TAck, which reads, in part, as follows: "In the early days, artists showed their works in public. We read the 
stories of competition decided by popular vote, of the birds who were deceived and of the populace who were deceived by the painted veil of Apelles. In the later Italian days paintings were exhibited on the Rialto, where the people became familiar with them, grew to know and understand them. Something of this is possible here. Fifth Avenue is our Rialto."

Another most interesting feature of the work done by this committee was placing a picture-frame, measuring eight by sixteen feet, in front of the New York Public Library, on which on twenty-two successive days was painted a picture typifying the spirit of one of the allied nations. $\mathrm{Mr}$. Charles B. Falls was the chairman of this committee. Among the twenty-two artists who painted these pictures were Mr. JAmes MonTgomery Flagg [Belgium], Lieutenant-Commander Henry Reuterdahl [British Empire], Mr. Charles S. Chapman [Cuba], Mr. F. Luis Mora [France], Mr. Grorge Wright [Greece], Mr. Charles B. Falls [Japan], Mr. Adolph Treidler [Montenegro], Mr. Jonas Lie [Panama], Mr. W. T. Benda [Poland], Mr. William J. Glackens [Russia], and Mr. Charles Dana Gibson [United States].

\section{XIV}

An Allied War Salon, one of the most significant and interesting exhibitions of pictures ever held in New York, was opened to the public on 9th December, 1918, remaining open until Christmas.

This exhibition was held under the joint auspices of the Division of Pictorial Publicity of the Committee on Public Information, the Mayor's Committee on National Defense and the American Federation of Arts. The Secretary of State, the Secretary of War, the Secretary of the Navy, the Acting British High Commissioner, the Ambassador of Italy and the Acting French High Commissioner were patrons.

The Allied War Salon, however, was not at all "official" in character, as that word is commonly interpreted. As a matter of fact, there were no committees, other than honorary ones, and no jury, but the entire material, some eight hundred items, was gathered by Mr. Duncan Phil- 
lips and the writer of this book, ably assisted in collecting the paintings by American artists by Mr. Augustus Vincent Tack.

As already noted, nearly two hundred drawings by our official artists in France were shown in this exhibition. A group of fifty or more American posters, including many originals, was shown, as well as some hundred carefully selected examples by French and British artists.

Sixty or seventy pictures by American artists, painted in this country, were the work of Messrs. Gifford Beal, Grorge Bellows, Ernest C. Blumenschein, Howard Russell Butler, Charles S. Chapman, Paul Dougherty, Charles W. Hawthorne, Albert Herter, Hayley Lever, Jonas Lie, George B. Luks, Gari Meichers, William Ritscher, Augustus Vincent Tack, Douglas Volk, Childe Hassam, J. Alden Weir and many other artists of reputation.

One of the most interesting exhibits was a group of thirtyssix paintings and drawings by the marine camoufleurs of the United States Shipping Board, Second District.

Drawings, lithographs and etchings in the American sections were the work of Messrs. George Wright, W. A. Rogers, Charles Dana Gibson, Louis Orr, Samuel J. Woolf, George Bellows, Childe Hassam, Hugh Ferriss, and Herbert Pullinger. Two landscape targets, one painted by Mr. Augustus Vincent TACK and one by Messrs. H. Bolton JoNEs and FrANCIS C. JoNEs, attracted much interest. Sculpture by American artists, with war subjects, about forty examples, completed the American exhibit.

In the large gallery given over to Great Britain was the set of lithographs depicting Britain's efforts and ideals in the Great War, as well as notable displays of the lithographs of Messrs. Frank BrANGwYN and G. Spencer Pryse.

One of the most interesting galleries in the exhibition was that devoted to the lithographs of MM. Lucien Jonas, Forain and Strinlen. Other French pictures were by MM. Renoir, Hermann Paul, Guy Arnoux, Bentto and ABeL FAIVRE, as well as many original drawings by M. LuCien JonAs. Eighteen original cartoons by M. RAemAekers and 
etchings by Messrs. J. C. Vondrous and Gianni Caproni completed the exhibition. Great interest was manifested in the etchings by Signor CAPRONI, who besides being the world's greatest designer of aeroplanes, is an etcher of considerable ability and has executed a number of plates depicting the aërial side of modern warfare.

\section{XV}

With Mr. Thomas Hastings as architect and Mr.PAulW. BartLetT as the chief sculptor, a temporary arch was erected at Madison Square and Fifth Avenue, New York, to do honor to New York's returning troops. This Victory Arch, about one hundred and fifty feet high, was the largest arch ever built in America. Surmounting this arch, which was an excellent piece of work, was a large equestrian group, the work of Messrs. Paul W. Bartlett and Attilio Piccirilli. This group showed a chariot, drawn by six horses and surmounted by a winged figure. On the main columns were panels by Messrs. DANIEL CHESTER French and Herbert AdAMs. The spandrils were by Messrs. Isidore Kontr and Andrew O'ConNor, while bas-reliefs were by GertrudeV. Whitney [Mrs. Harry Payne Whitney], Mr. Mahonri Young, and fourteen other sculptors.

The art committee of the Liberty Loan Committee was responsible for a well-designed Victory Way on Park Avenue, New York. Rows of Doric columns formed the two sides of the scheme. A frieze of paintings supplied a background to the speakers' rostrum. Mr. ARTHUR CRISP had a painting of Victory in the center, and Mr. J. Monros Hewlett paintings of New Zealand and Australia, while South America was painted by Mr. Charles S. ChAPMAN and North America by Mr. Frederick J. Waugh. Mr. W. T. Benda painted Europe and Mr. Arthur Covey Africa. The color scheme was the same in all of these paintings, as well as the scale, and this collaboration worked for harmony. Simplic' ity was the key-note of this notable achievement. The same committee placed pictures of scenes connected with the war in many of the prom. inent windows on Fifth Avenue. 


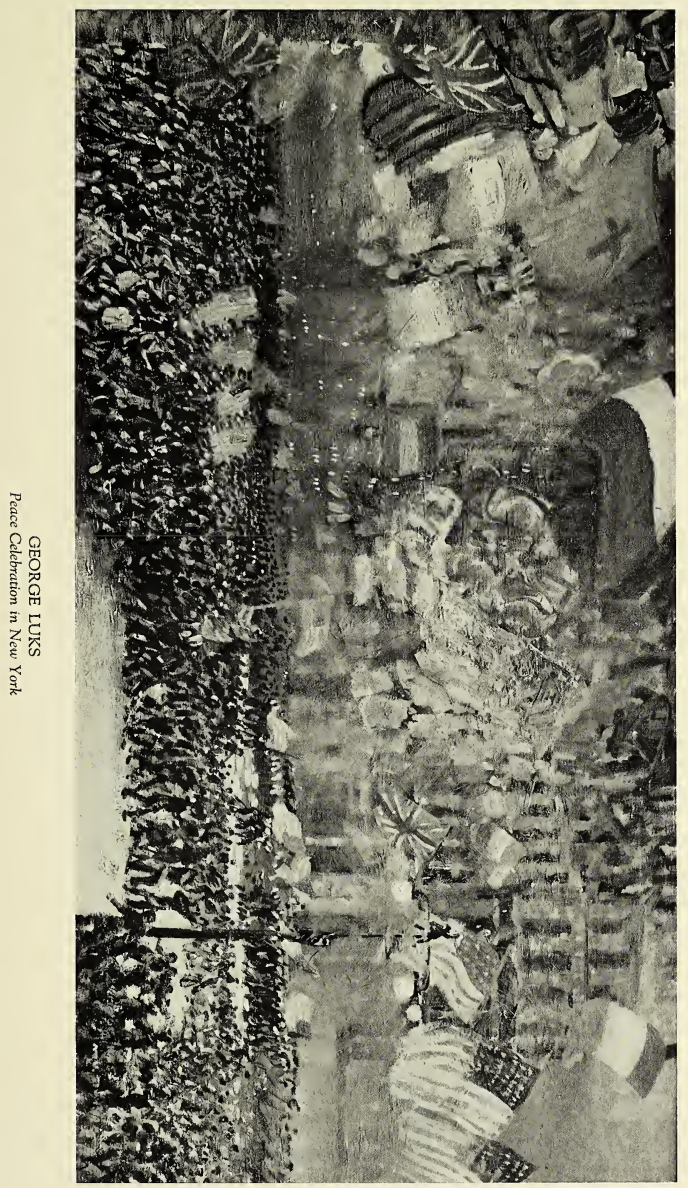





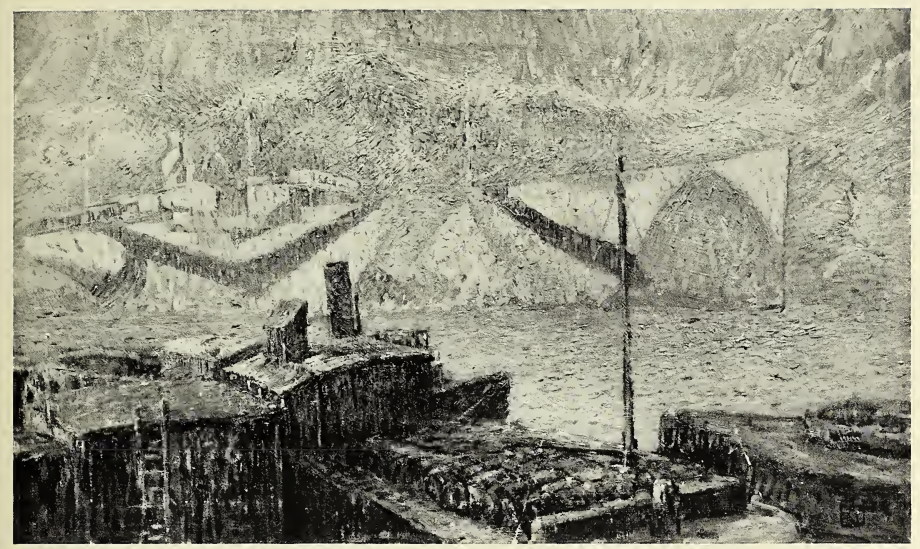

SPENCER B. NICHOLS

The Tanker 



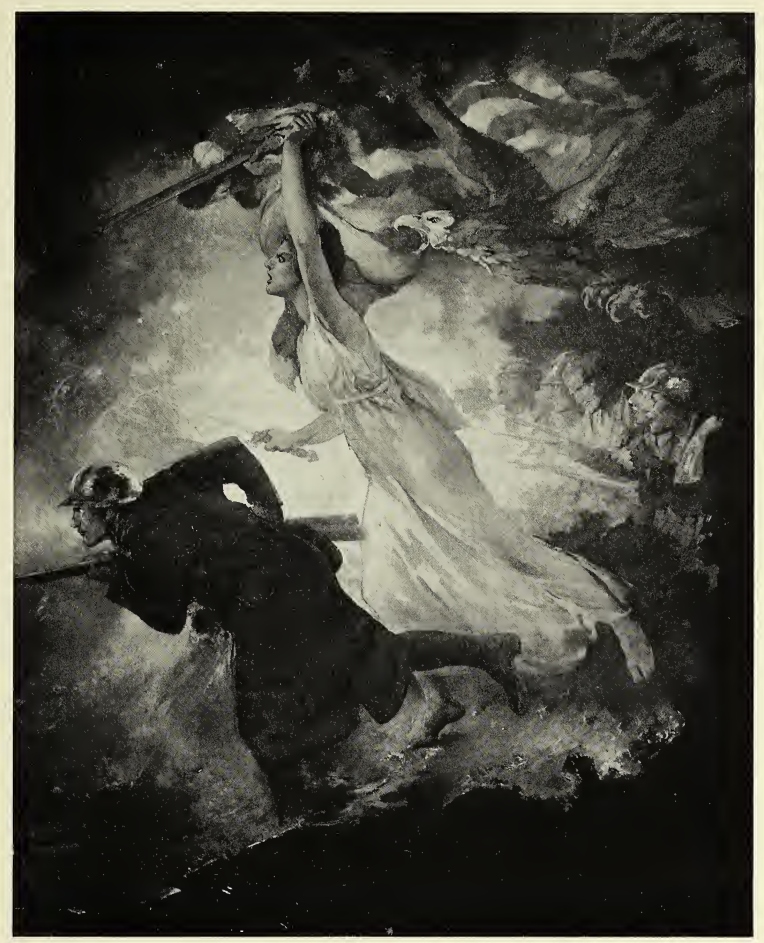

EDWIN H. BLASHFIELD

Carry On 



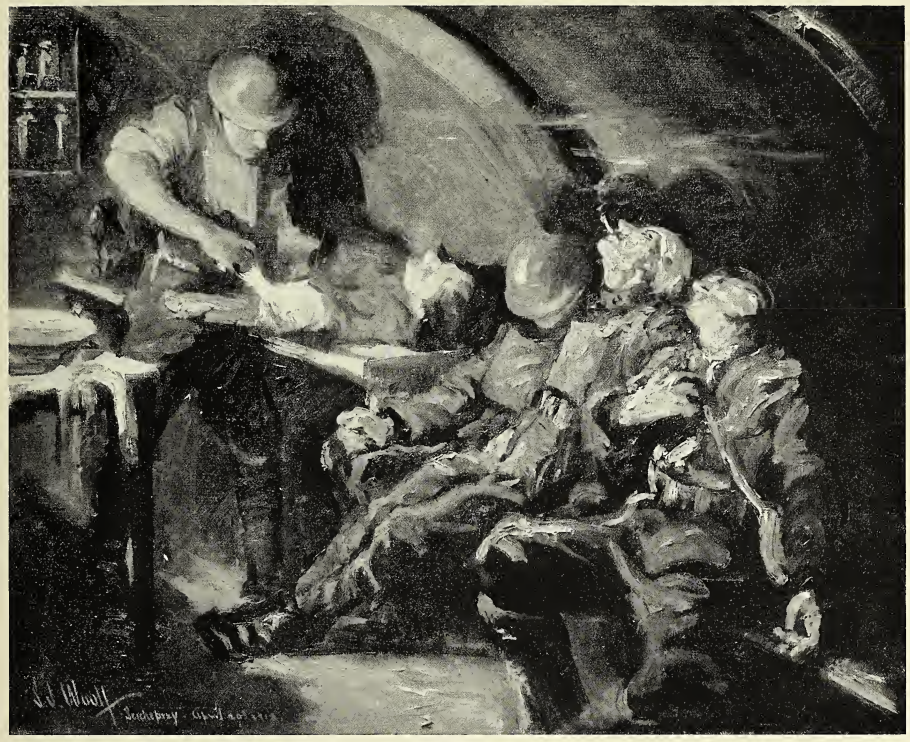

SAMUEL J. WOOLF

First Aid Station at Seicheprey 



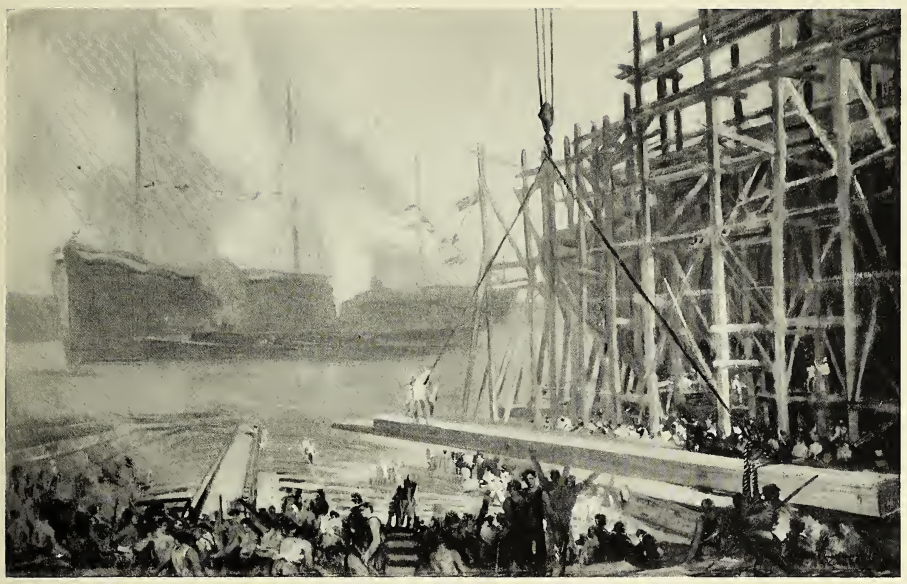

JOHN C. JOHANSEN

The Launch of the Watonwan 



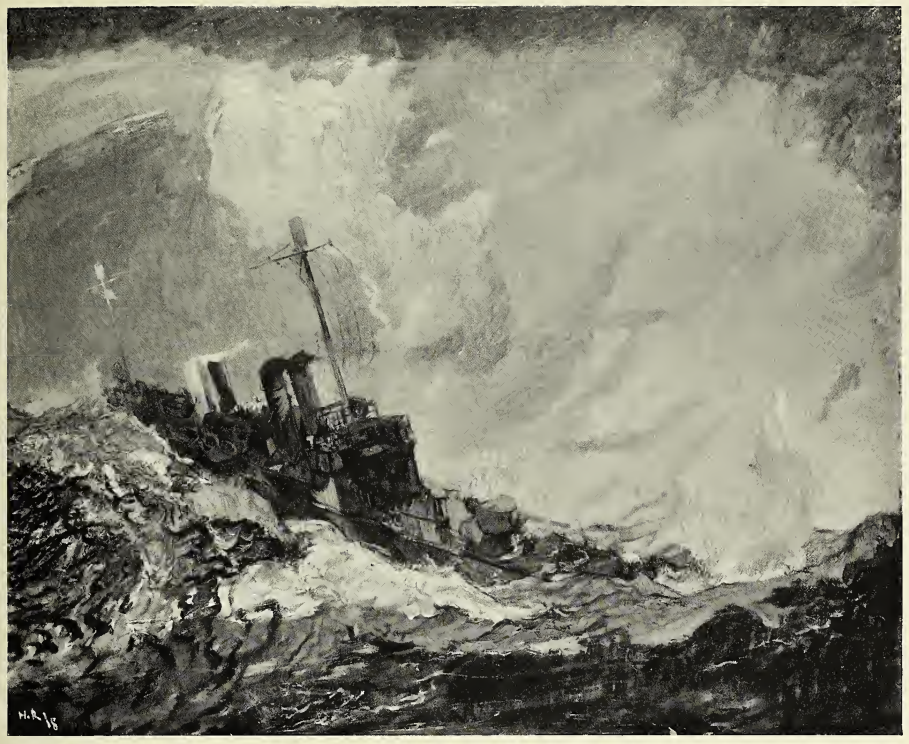

HENRY REUTERDAHL

The Destroyer Patrol 



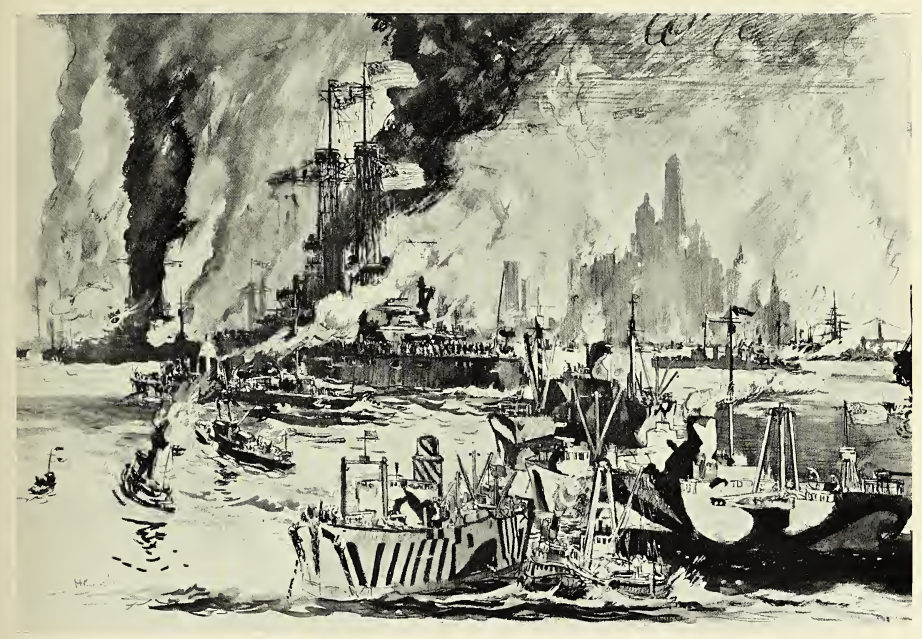

HENRY REUTERDAHL

The Return of the Victory Fleet 



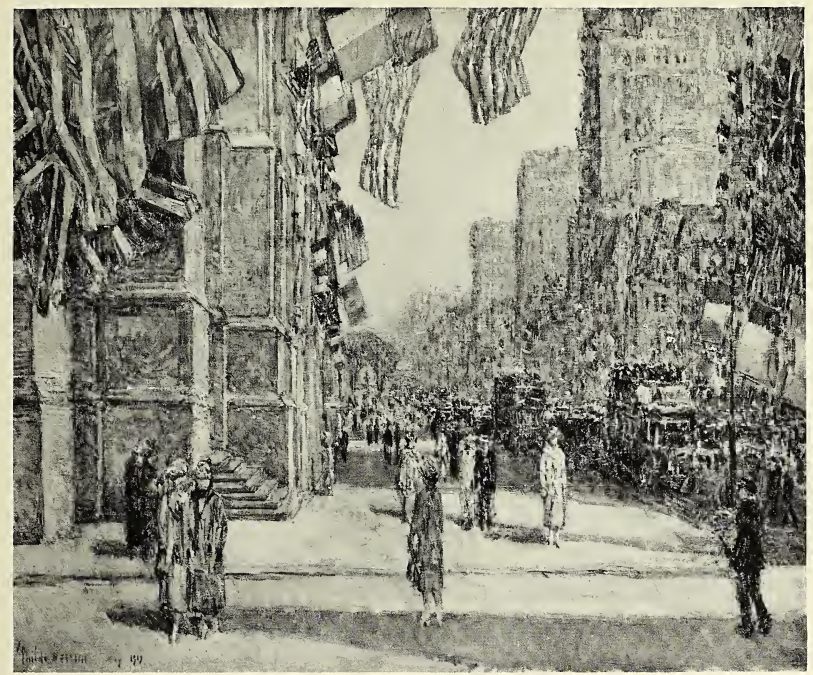

CHILDE HASSAM

Early Morning on Fifth Avenue, May, 1917 



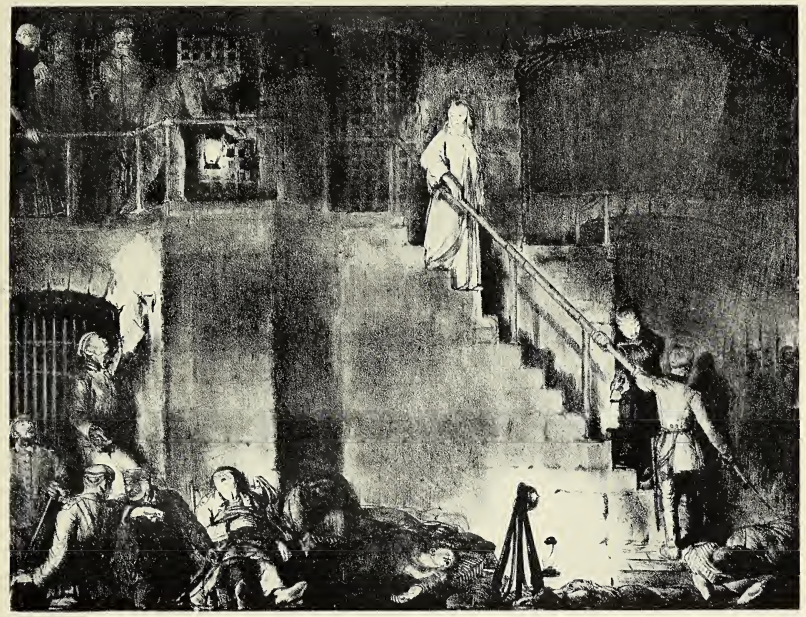

GEORGE BELLOWS

Murder of Edith Cavell 



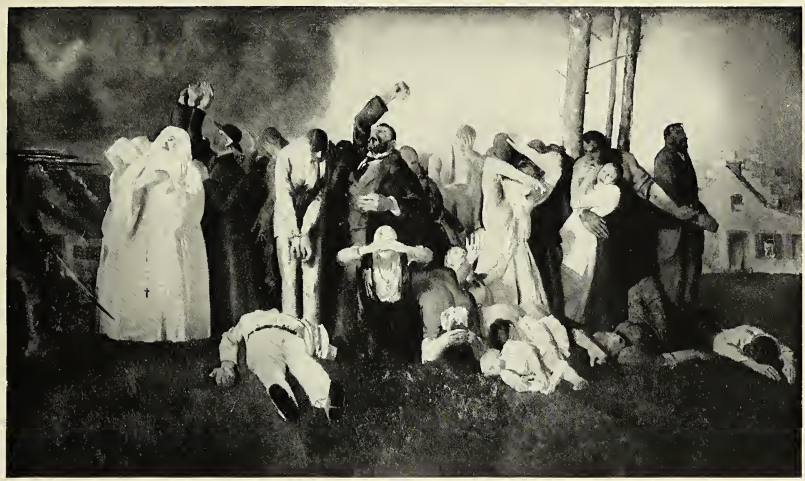

GEORGE BELLOWS

Massacre at Dinant 


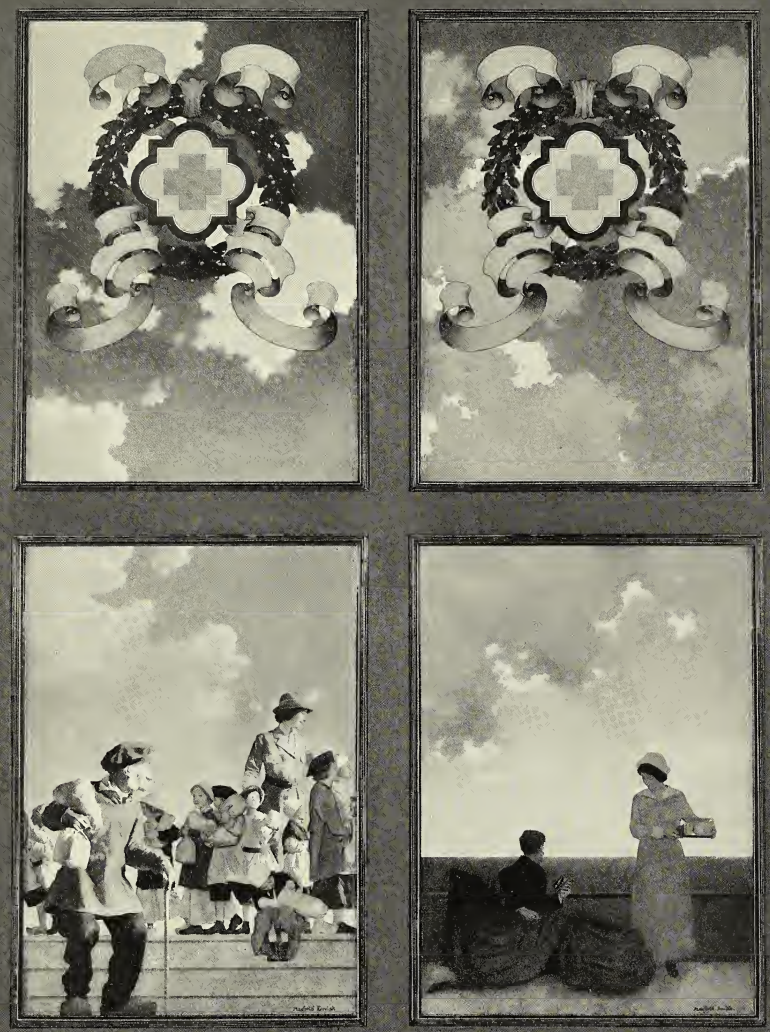

MAXFIELD PARRISH

Design for the Red Cross 



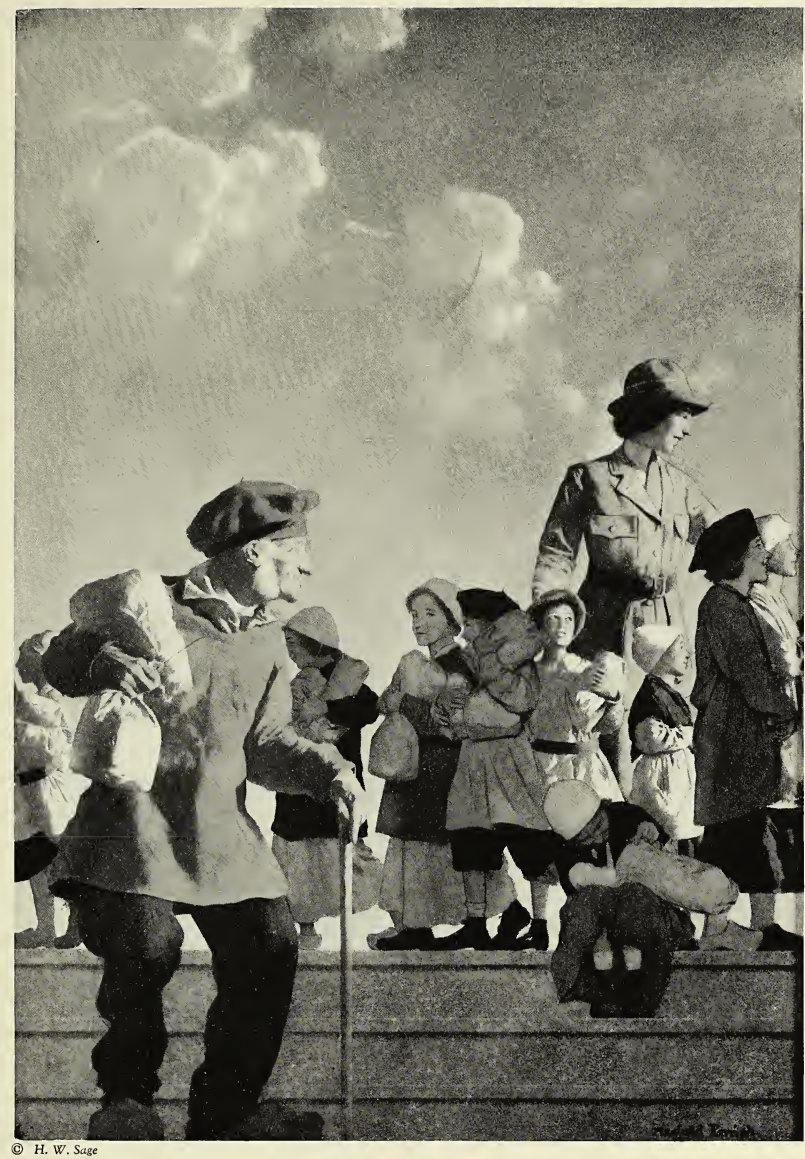

MAXFIELD PARRISH

Design for the Red Cross: Detail 



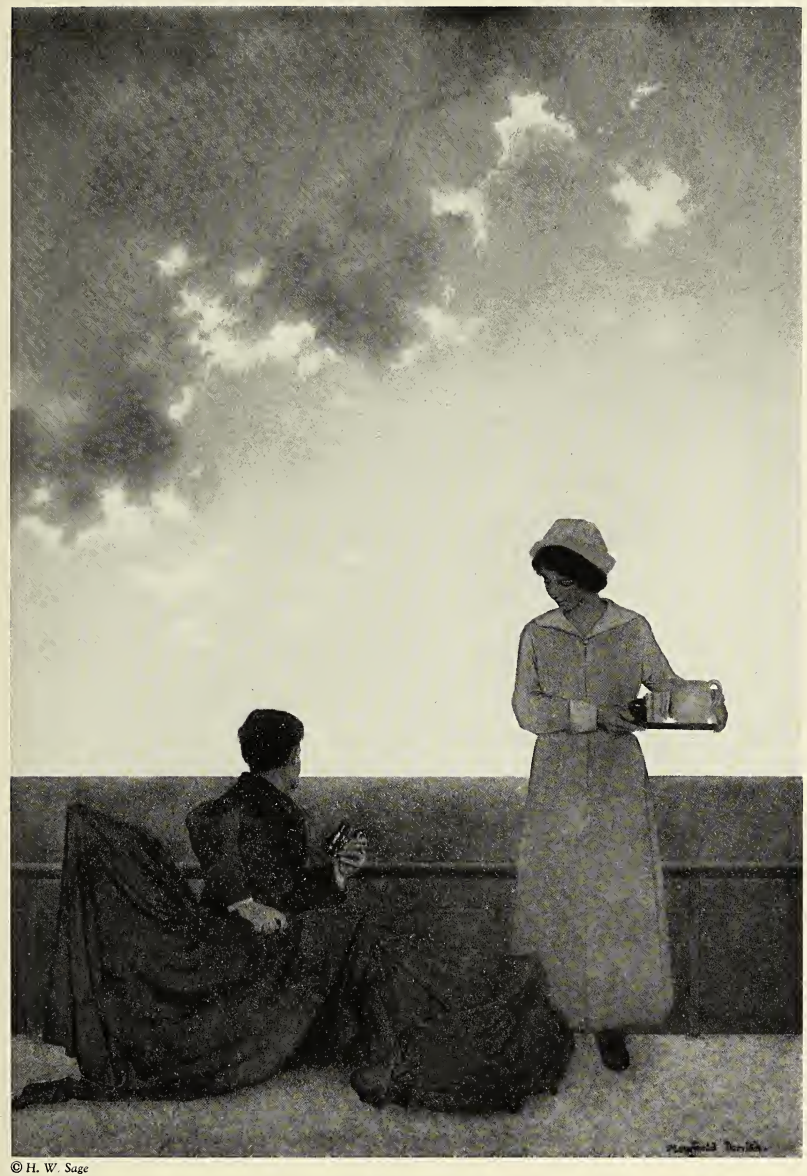

MAXFIELD PARRISH

Design for the Red Cross : Detail 



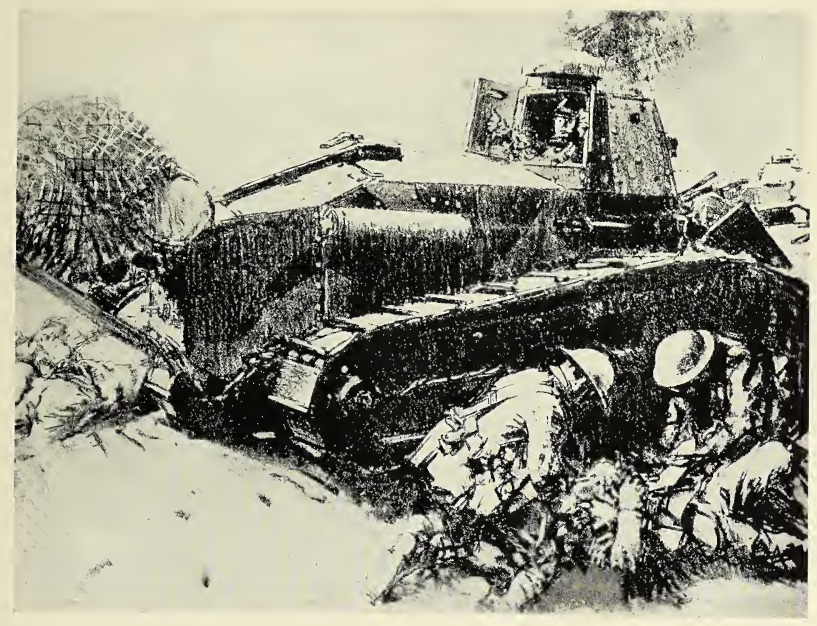

HARRY E. TOWNSEND

A Wounded Tank 



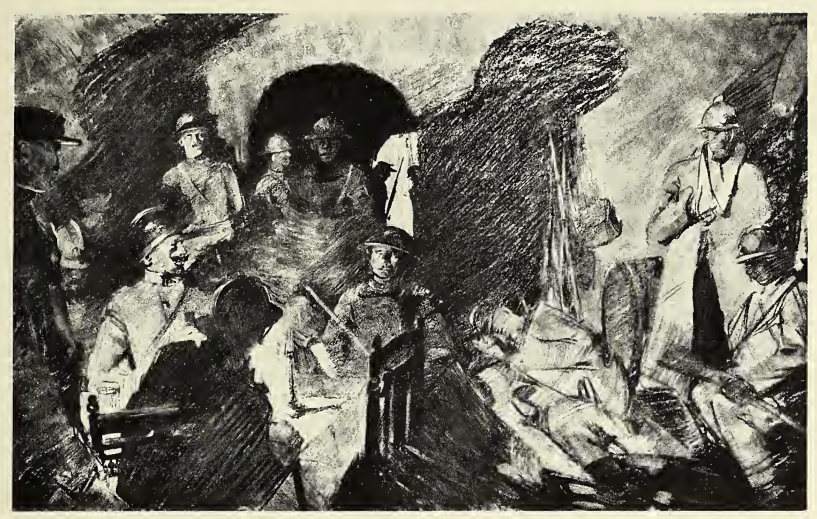

GEORGE HARDING

An American-French Conference in a Wine Cellar, Château-Thierry 



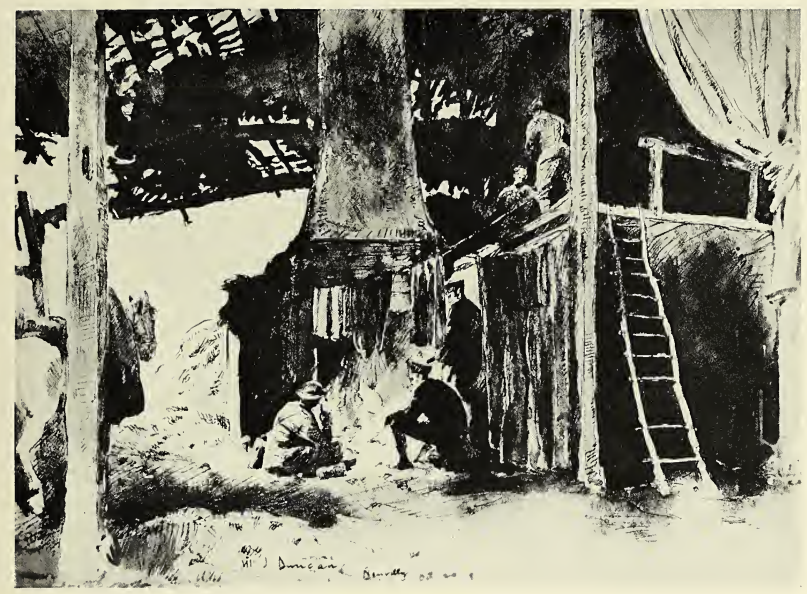

WALTER J. DUNCAN

Cold Nights Coming On 



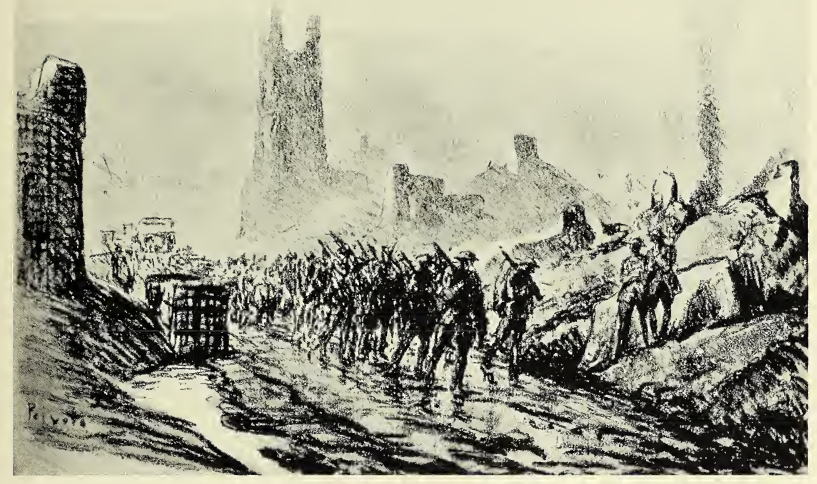

ERNEST PEIXOTTO

Troops Leaving Esnes, September 23, 1918 



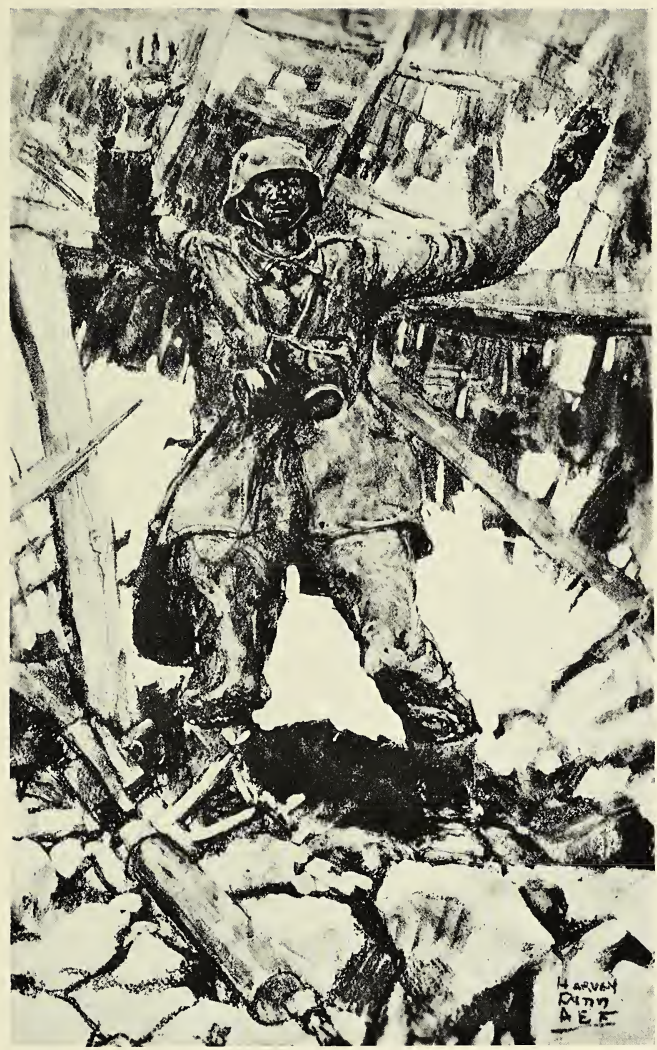

HARVEY DUNN

Kamarad-The Sniper 



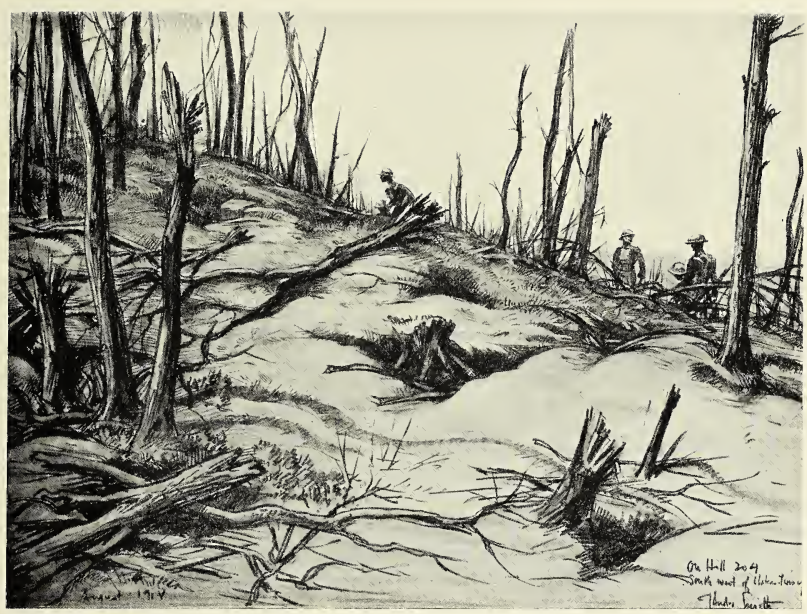

J. ANDRÉ SMITH

On Hill 2044-Southwest of Château-Thierry 



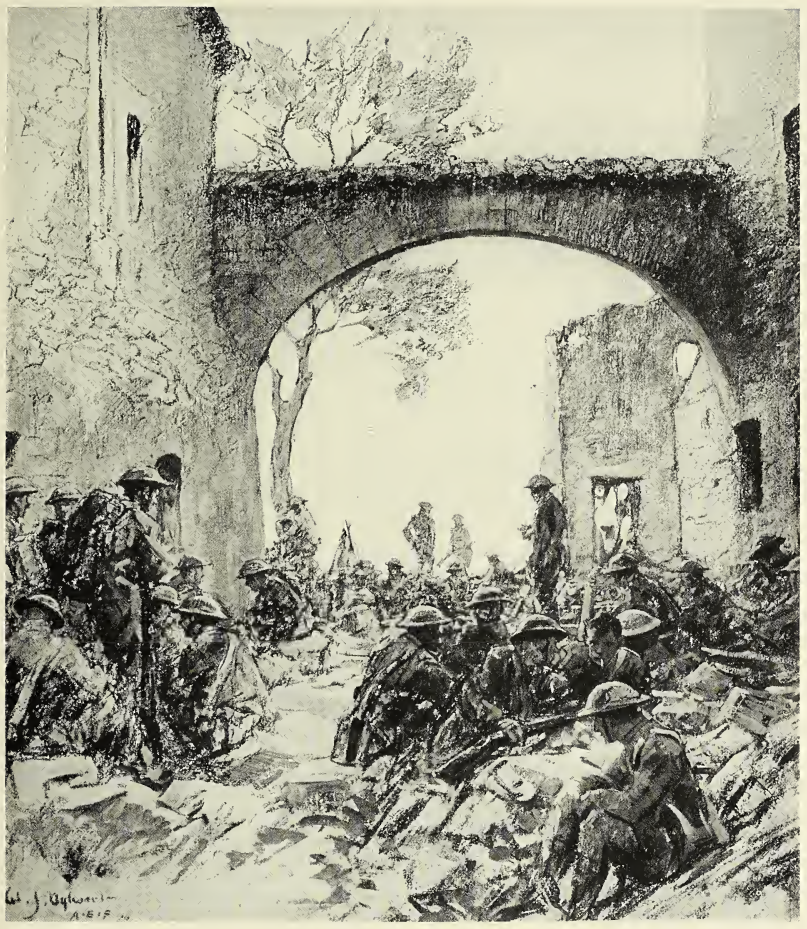

WILLIAM J AYLWARD

TroopsWaiting to Adeance at Hatton-châtel, Meuse-S. Mihiel Drive 



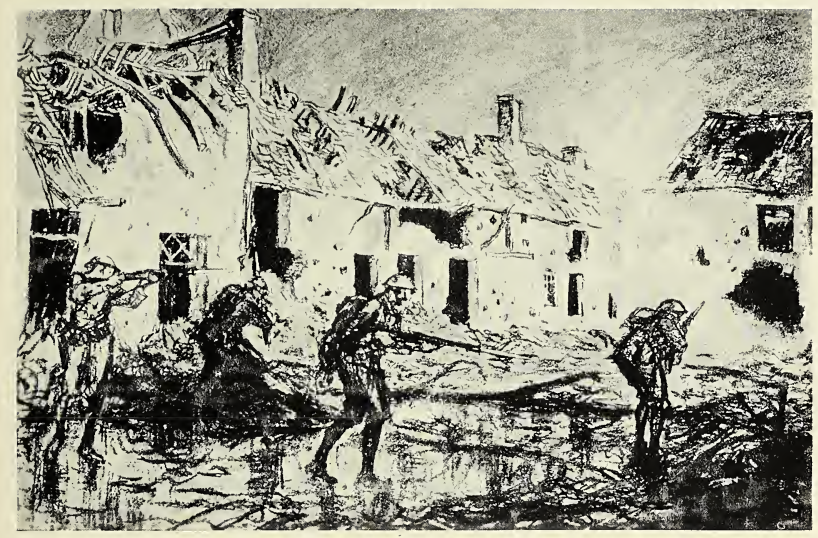

WALLACE MORGAN

Americans Mopping up in Cièrges 



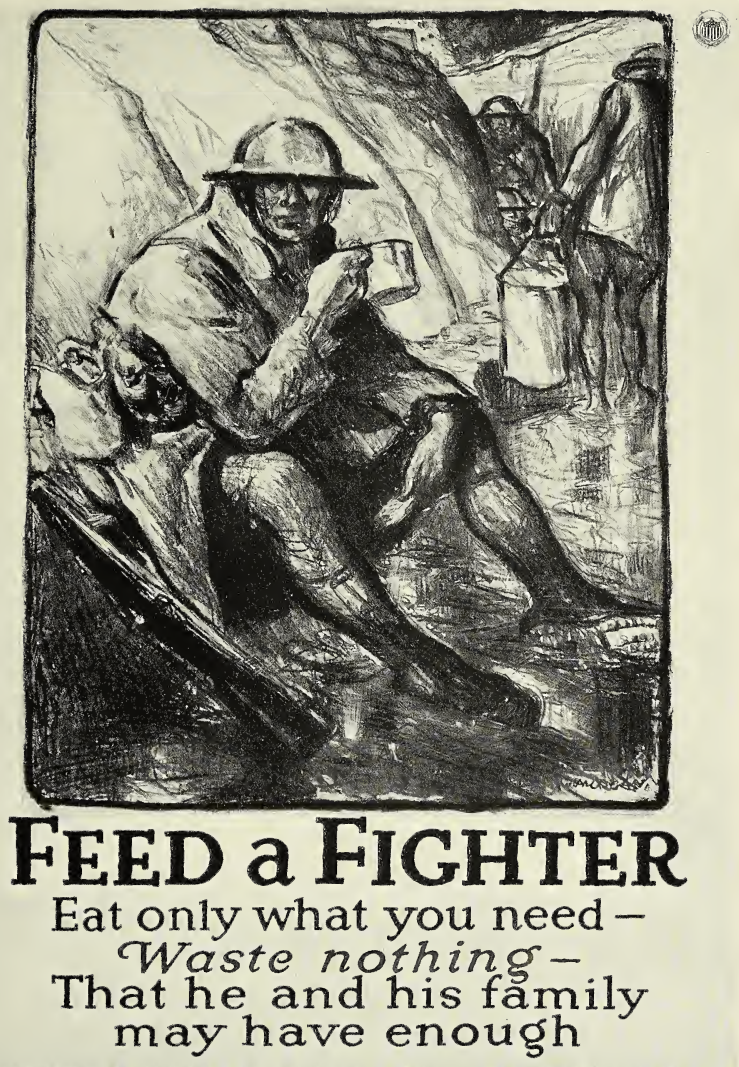





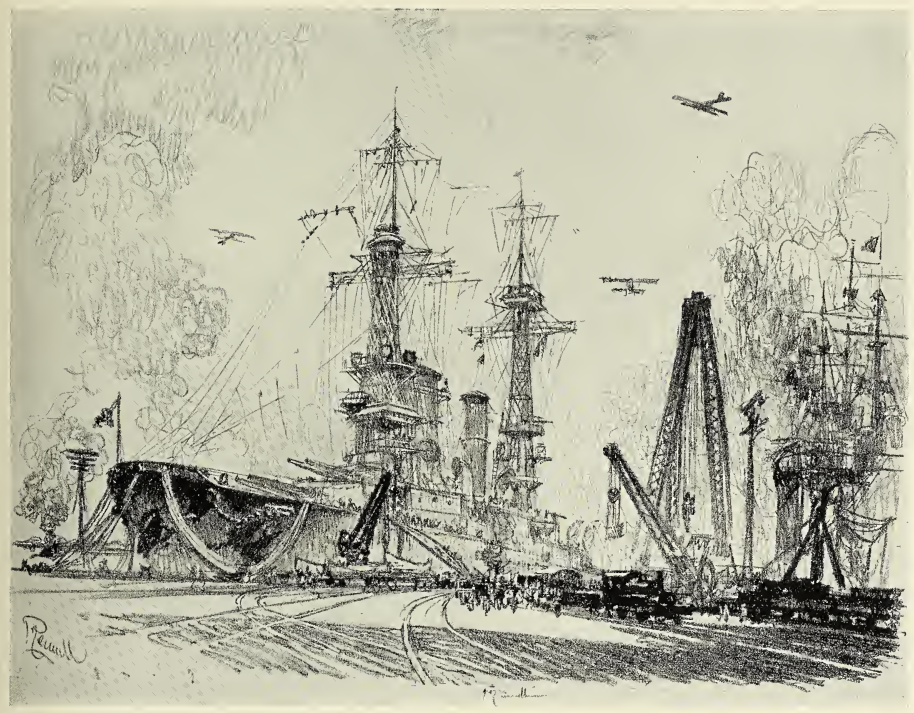

JOSEPH PENNELL

Ready to Start 



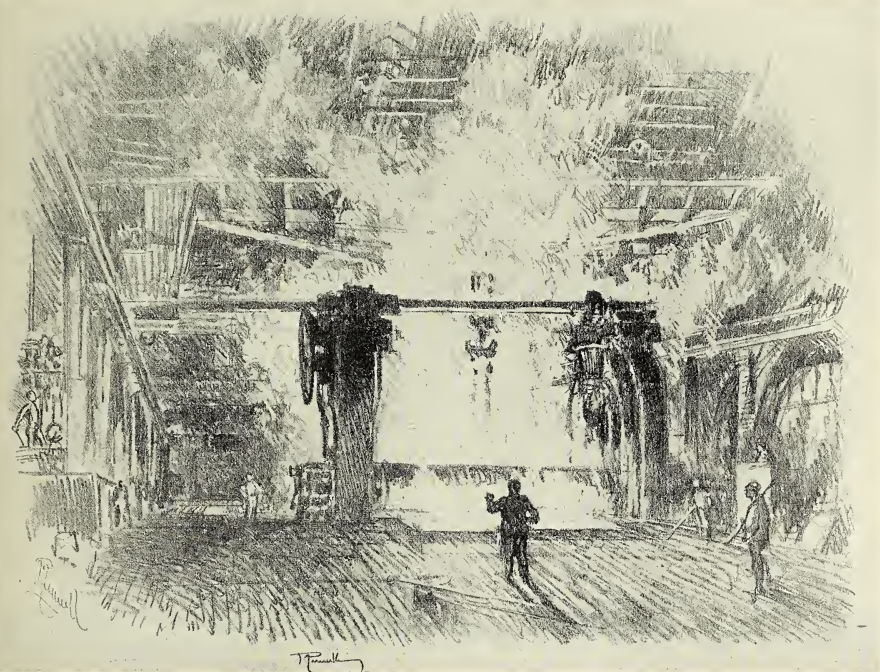

JOSEPH PENNELL

Making Armor Plate (England) 


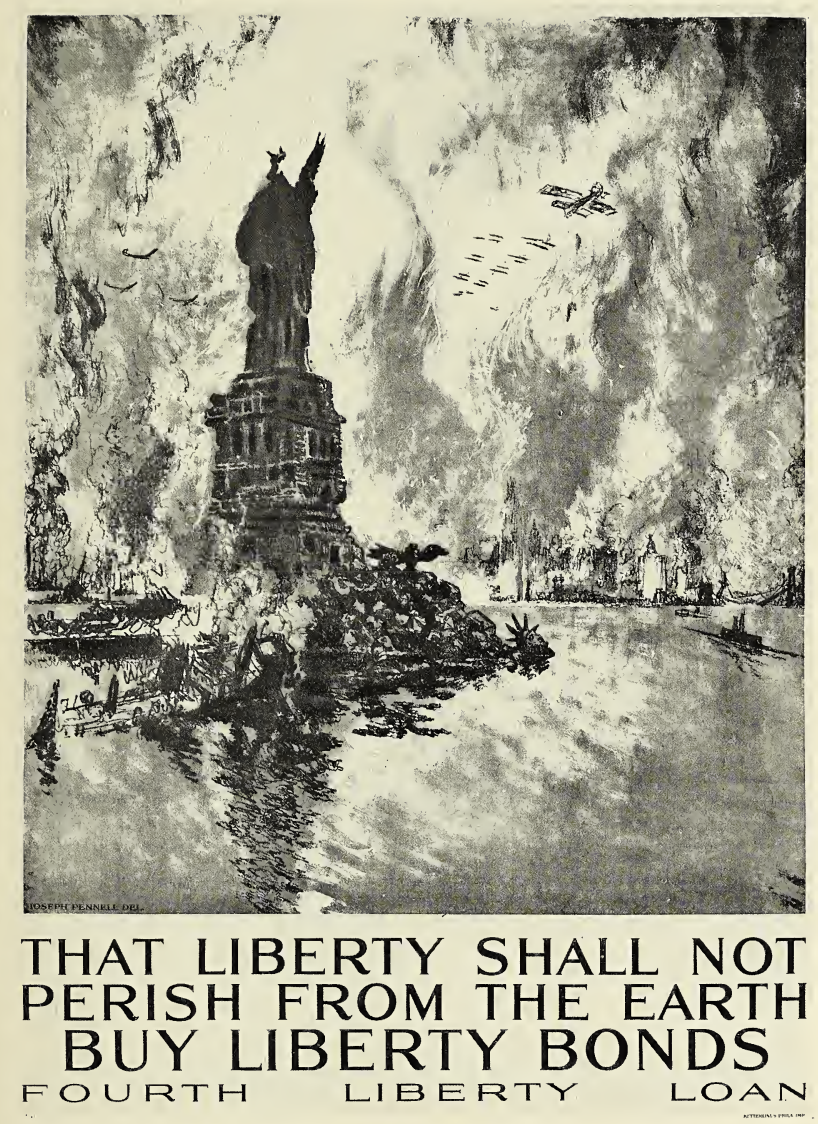

JOSEPH PENNELL

That Liberty Shall Not Perish from the Earth 



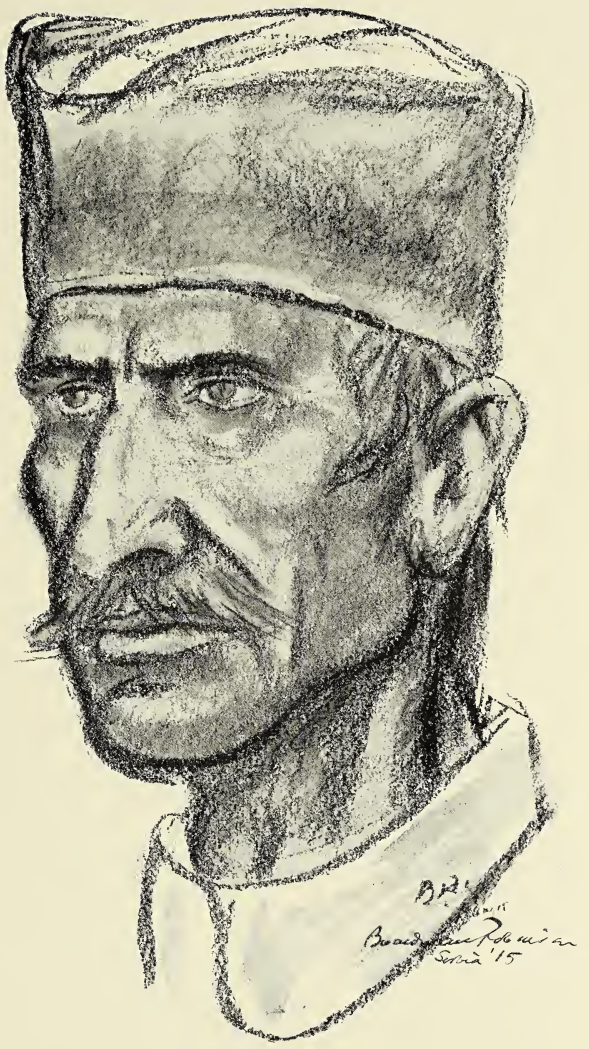

BOARDMAN ROBINSON

The Serb 



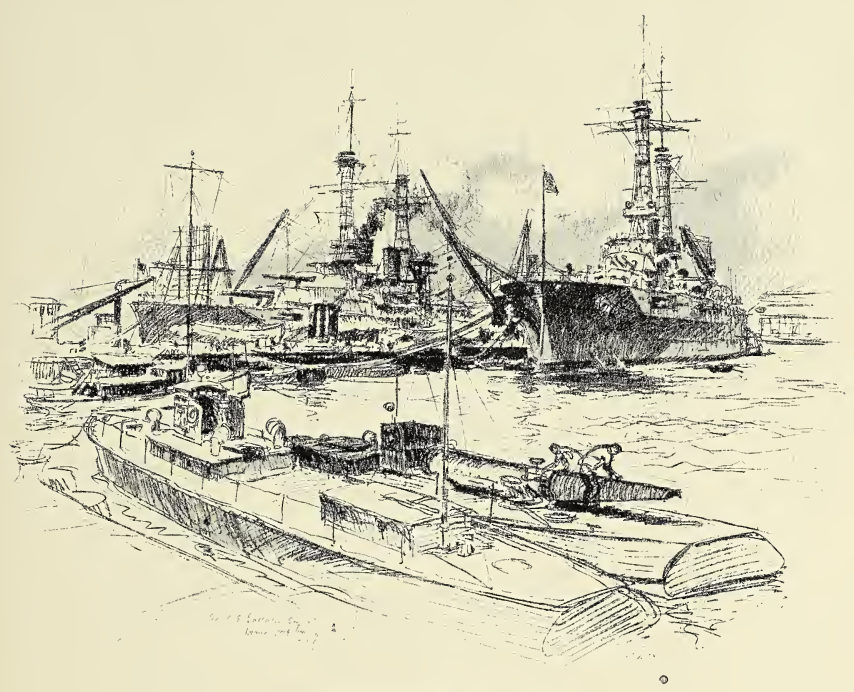

VERNON HOWE BAILEY

The Superdreadnoughts New York and Arizona 



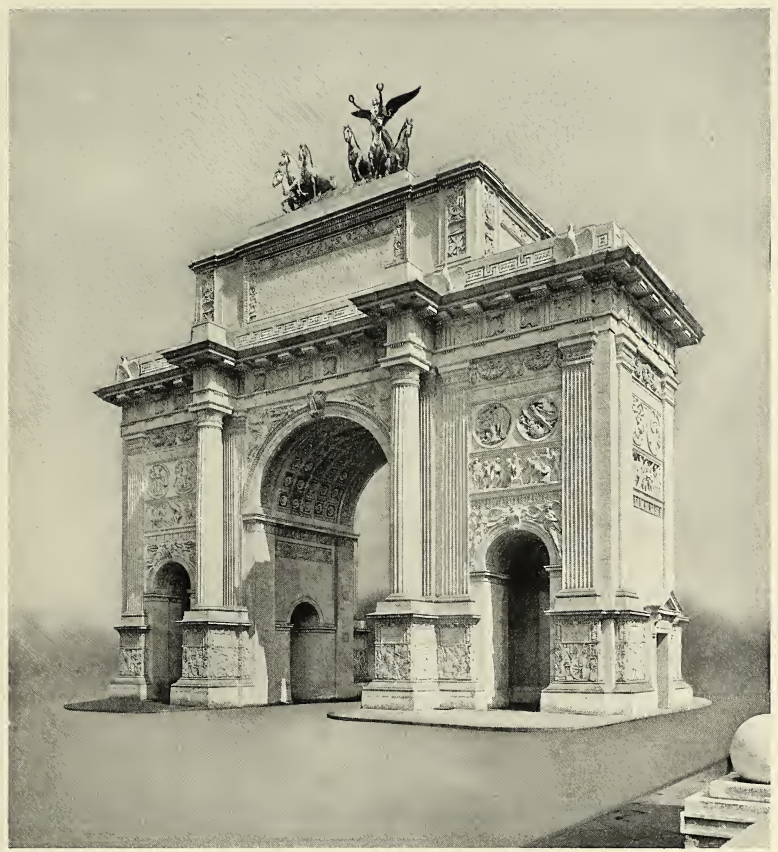

THOMAS HASTINGS

Victory Arch, New York 


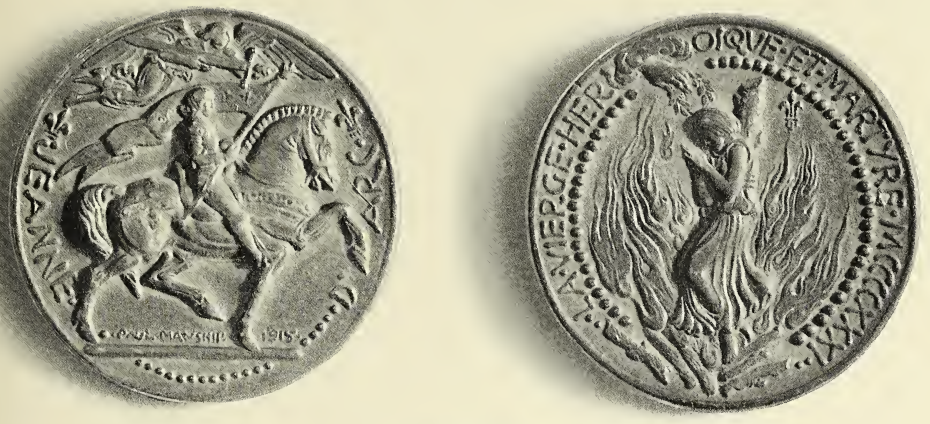

PAUL MANSHIP

Jeanne d'Arc Medal 



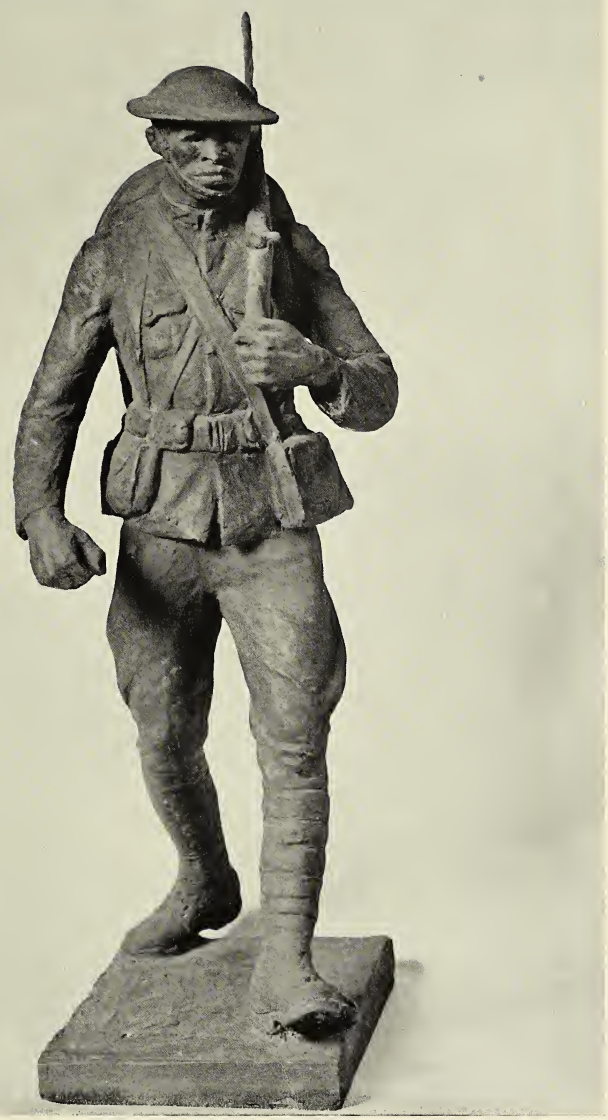

MAHONRI YOUNG

One of the "Buffaloes" 



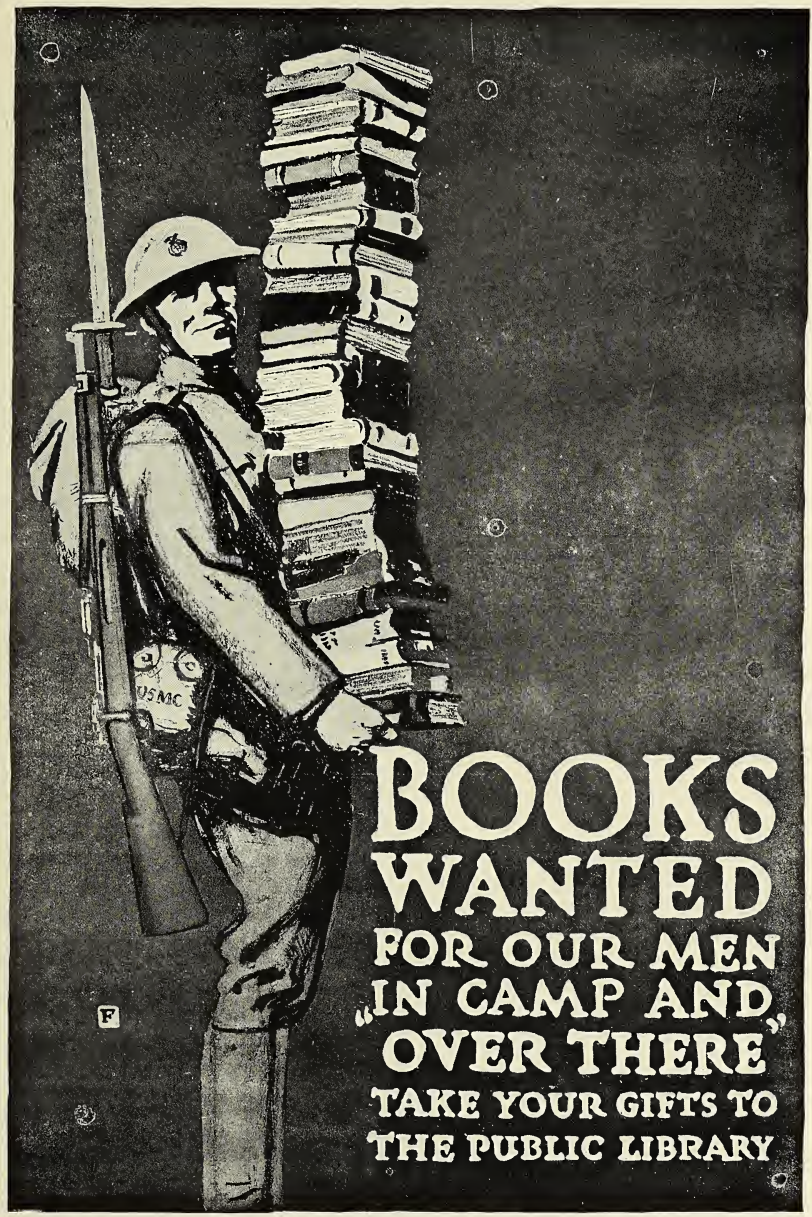

C. B. FALLS

Books Wanted 



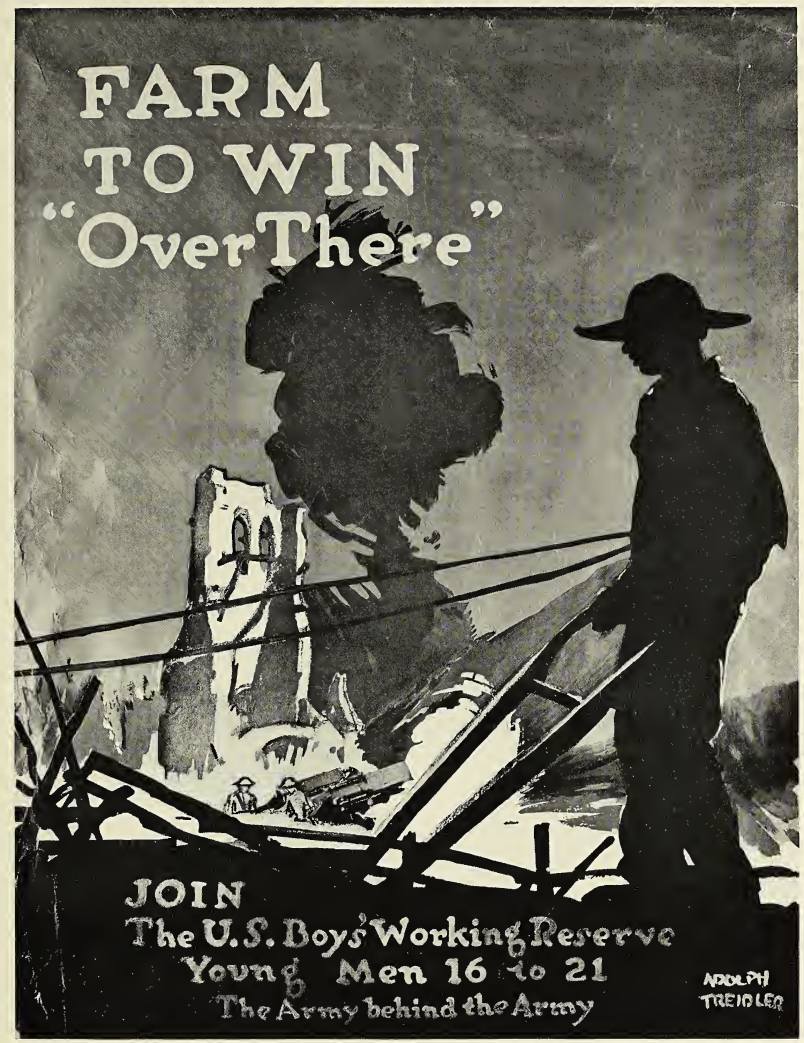

ADOLPH TREIDLER Farm to Win "Over There" 



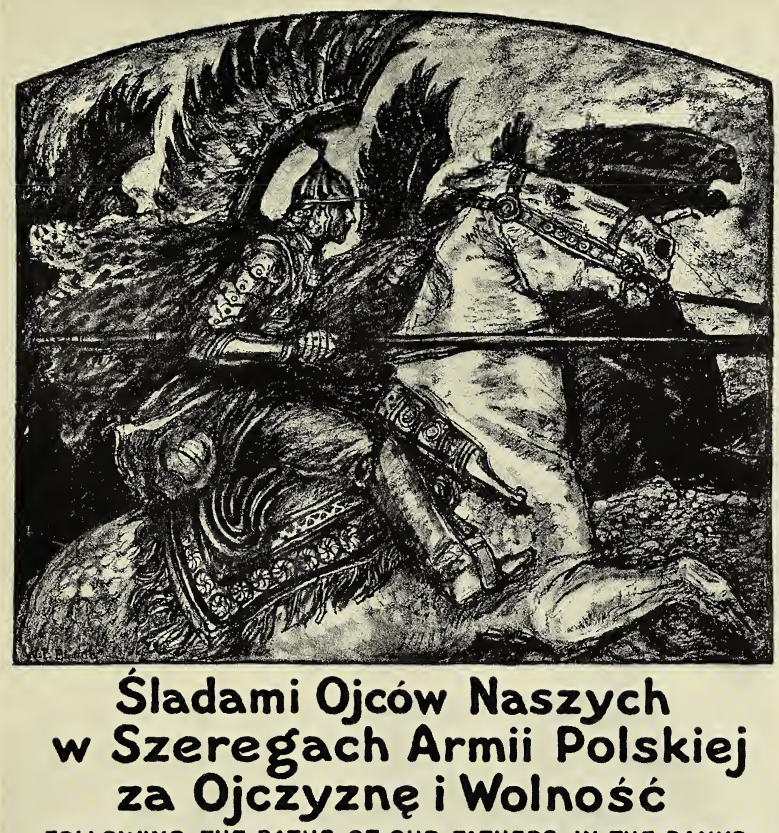

FOLLOWING THE PATHS OF OUR FATHERS IN THE RANKS OF THE POLISH ARMY FOR MOTHERLAND AND FREEDOM

W. T. BENDA

For Motherland and Freedom 



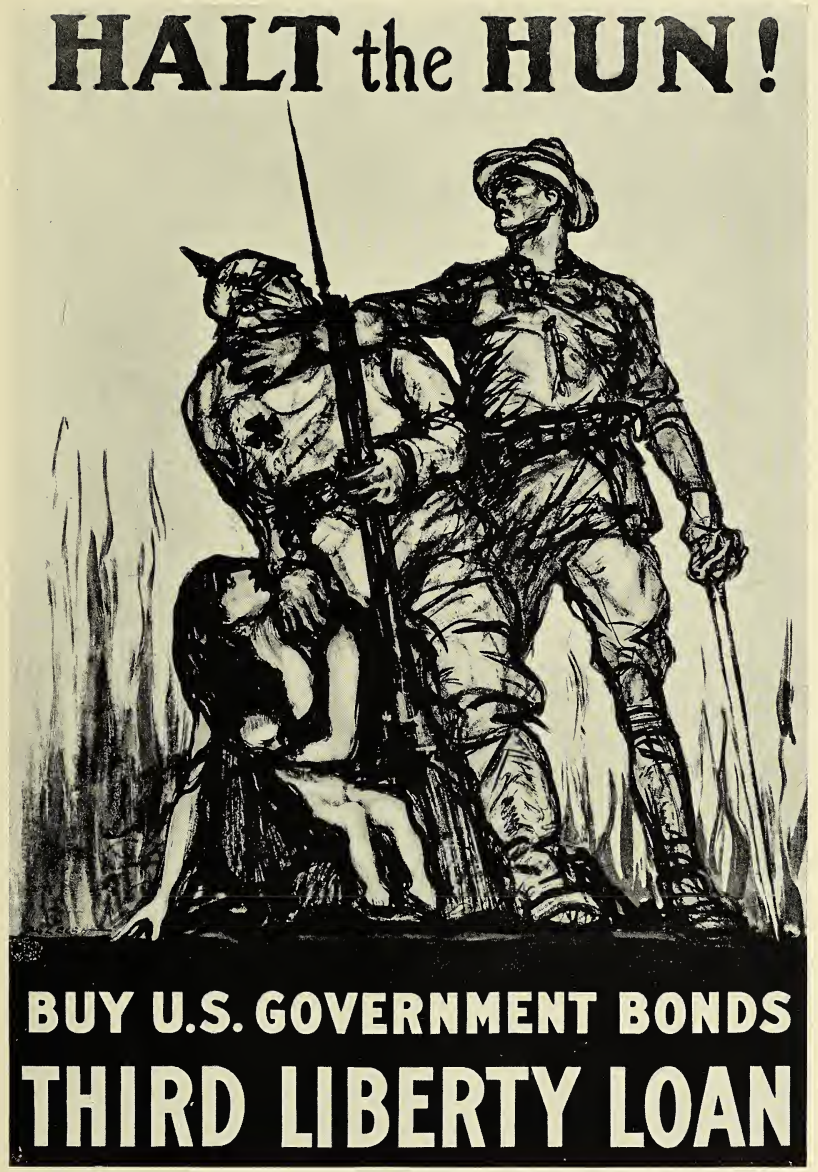

HENRY RALEIGH

Halt the Hun! 



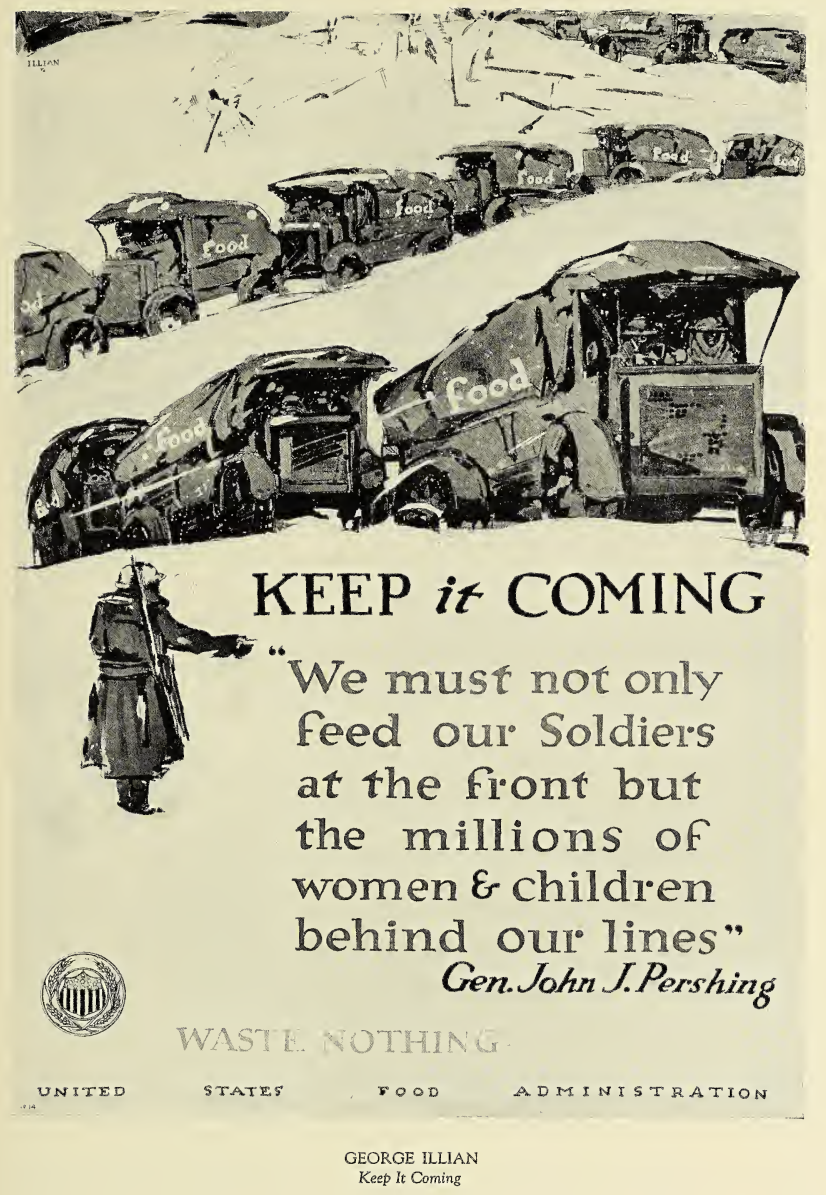





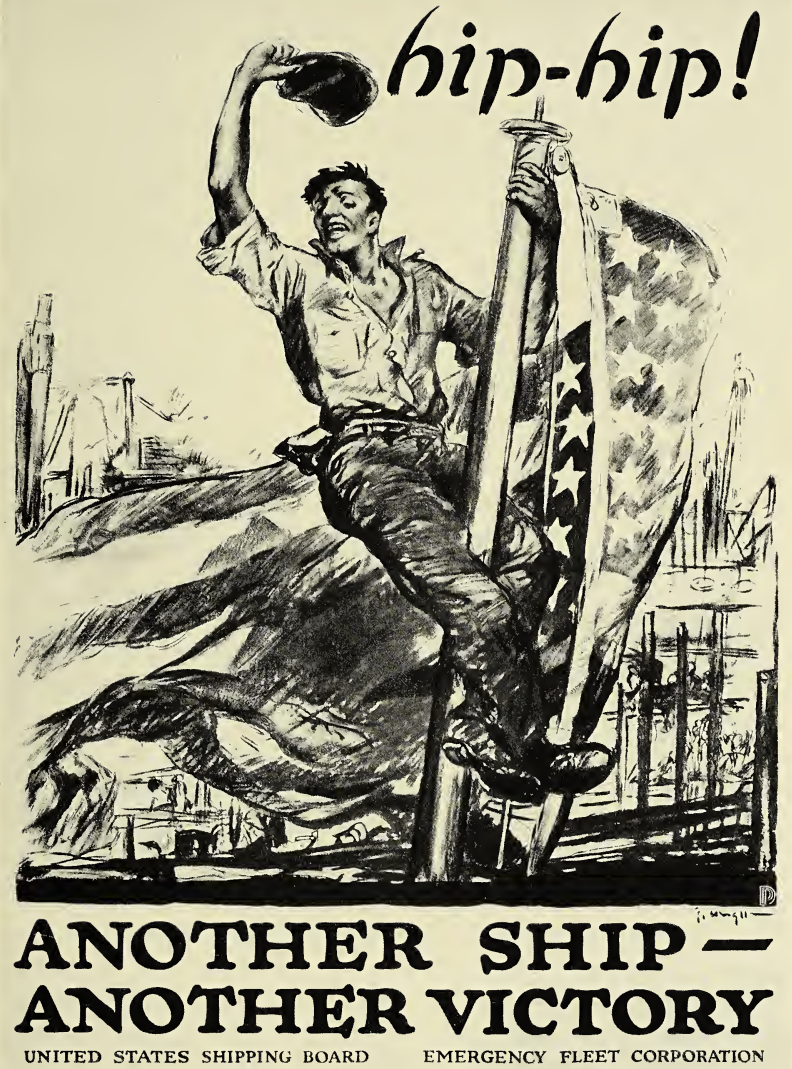

GEORGE WRIGHT

Another Ship-Another Victory 


GREAT BRITAIN AND CANADA 


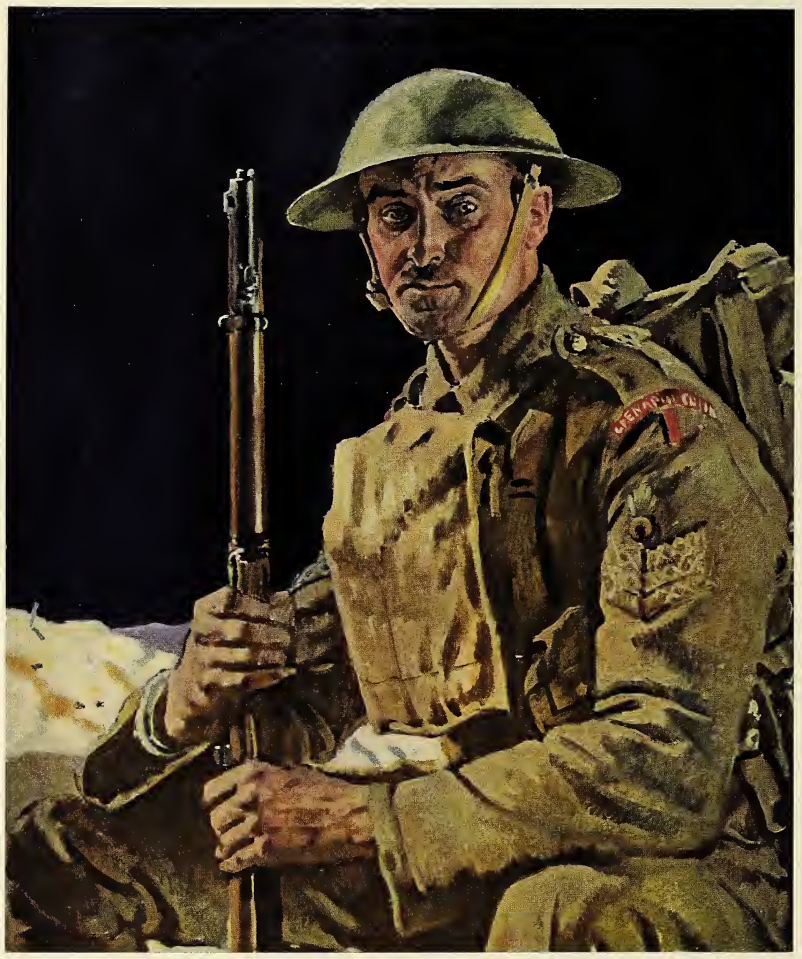

WILLIAM ORPEN

A Grenadier Guardsman 


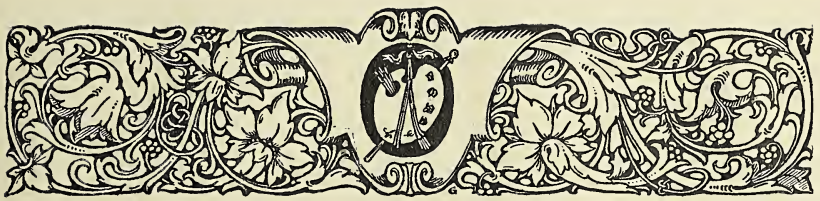

\section{CHAPTER TWO}

\section{GREAT BRITAIN AND CANADA}

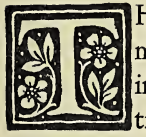

HE greatest credit should be given to the British Government for the foresight and judgment displayed in dispatching artists of real ability to France. That the British authorities did not select popular shams when they finally decided to permit artists to go to the front is as commendable as it is astonishing. One would have imagined that the official war artists would have been chosen from the conservative and uninspired painters of typical Royal Academy anecdotes. But nothing of the sort was done; on the contrary, England sent her most vigorous and original men. She has, in consequence, a very adequate pictorial record of the Great War, a record which far outstrips that of any other country, Canada only excepted. France was left far behind and the United States is nowhere atall. Stress should also be laid upon the fact that Great Britain gave her artists a free hand and imposed no restrictions of any kind upon them: they were at perfect liberty to go where they chose and to do what they wanted. This accounts in large part for the excellence of their work. The offcial American artists, on the other hand, lacked proper direction and were not given facilities until quite late for carrying on their functions.

Great Britain chose wisely in selecting such artists as Sir William Orpen, Messrs. C. R. W. Nevinson and Eric H. Kennington to depict the activities of her armies in France, and Mr. JAMEs McBeY to record her campaigns in Palestine and Egypt, and no other living artist could 
have recorded the environment of the British army and Royal navy as well as Mr. Muirhead Bone. Excellent, too, are the sea paintings of Sir JoHn LAvery. These artists, to mention but a few, not only produced work quite worthy of them, but in many instances their art was actually broadened and developed by the war. Mr. John S. SARGENT also painted some pictures in France; one of them is entitled Gassed, and shows a procession of gas-blinded soldiers groping their way across a battlefield.

The majority of these fine works, it is gratifying to know, are to be deposited in the Imperial War Museum in London or in the Canadian War Memorials in Ottawa, where they will always be viewed with interest and prove a source of inspiration to coming generations.

\section{II}

Under the auspices of the Ministry of Information, a representative selection of the paintings and drawings, with a few lithographs, which were made for the Imperial War Museum were sent to this country. The exhibition was first shown at the Corcoran Gallery in Washington, ' in January, I919, afterwards coming to New York, and then shown throughout the country, with the coöperation of the Worcester Art Museum. This exhibition, which comprised two hundred and forty-one numbers, gave an excellent idea of the pictorial records which Great Britain possesses of her part in the Great War.

One hundred and two of the total number of pictures included in this exhibition were paintings and drawings by Sir WILLIAM ORPEN, who was gazetted a major in the Army Service Corps. This group of portraits, studies of types, of battlefields and other subjects comprised, I believe, about one-half of the total amount of work done by him. Major ORPEN's series of portraits of British officers and soldiers, as well as one of Marshal Foch, are most dextrous and brilliantly clever pieces of painting. Rapidly executed, with the background often left unfinished, they possess the freshness of sketches. I am sure that all of ORPEN's portraits are capital likenesses and also that he has got considerable of the sitters' personali, 
ties fixed upon his canvases. Painted with a very high-keyed palette, as are the portraits, Major ORPEN's pictures of battlefields and views of the town of Cassel, where he made his headquarters, are also very realistic. His pencil drawings are a delight and rank in technical interest above the paintings: but in spite of all the evidence of technical ability shown in them, they are a little hollow and they display no feeling. They appear cold and lacking in sympathy when compared with the eloquent and moving lithographs of M. STEINLEN and Mr. PRYSE. However, posterity will undoubtedly set a high value upon all this splendid work, so ably executed by one of the most prolific of all the war artists. It is a record of which the artist may well feel proud and which the British nation may congratulate itself upon owning.

Noartist has touched upon as many sides of the war as Mr.MuIRHEAD BoNE, the famous etcher, and no artist has given us more faithful and artistic records. He has worked at the navy yards, he has visited the Grand Fleet and he has made many drawings on the western front, of which latter drawings Field-Marshal Sir Douglas Haig has said: "They illustrate admirably the daily life of the troops under my command." His draughtsmanship is well-nigh faultless; his landscapes, executed in pencil and wash, are among the greatest landscape drawings made since the time of Rembrandt, with whose drawings, in absolute mastery and emotional appeal, they are comparable. Mr. Bone's vision is always that of a true artist; his line is most intelligent and displays great learning, a line which is at once extremely delicate and full of great strength and power. No artist has made a more notable series of drawings of the war than Mr. Bone. His naval subjects are miles ahead of those attempted by any other artist.

Mr. JAMES McBey, a Scotsman, favorably known before the war for his beautifully drawn dry'points and water-colors, was sent to Palestine and Egypt in his capacity as official artist and in these countries he made a great number of very sensitive and interesting drawings.

With a commendable spirit of broadmindedness and fairness, Great 
Britain also included among her official artists converts to the teachings of the Post-Impressionists, the Cubists, the Expressionists and the Futurists. Chief among these artists was Mr. C. R. W. Nevinson, a Futurist, who has done some extremely interesting work. Mr. Nevinson has always been thoroughly alive and intensely interested in all the newer manifestations of art. Impressionism at first claimed his attention, then Cubism and its geometric formula, Expressionism and Futurism. Out of all these teachings and theories and influences he has evolved a style which might be described as a compromise between Futurism and illustration. His art is always dynamic and concerned with synthesis and abstraction. Pattern and design are also vital matters in his art. Mr. Nevinson was a motor mechanic and ambulance driver in Flanders the first year of the war; afterwards he was with the French army as an hospital orderly. In July, I9I7, he was appointed one of the official British artists. Mr. Nevinson has thus seen the war from many and varied angles. It has always been his endeavor to get at the truth: his pictures are entirely free from all music-hall and journalistic heroics. Soldiers, I believe, are unanimous in their praise of these pictures, saying that they depict the very soul of the war. The artist has done considerable flying and his paintings of aeroplanes are really remarkable. In such a lithograph as the Swooping on a Taube the speed of the plane is rendered in a marvelous manner; the rhythm and swinging motion that he gets into columns of marching men is also very wonderful. From his dazzling paintings Mr.Nevinson has executed lithographsand dry-points of great distinction. Working in these mediums, he has also made many equally engaging compositions of subjects not connected with the war. $\mathrm{He}$ is a dry-pointer possessing considerable skill and a lithographer who gets a beautiful lithographic quality into his drawings. Mr. PAuL NAsH has successfully painted the utter desolation of the shell-torn landscape. Messrs. William P. Roberts, John Nash and P. Wyndham Lewis were among the other modernists.

Among other interesting works in the exhibition sent to America by [136] 
the British Government was a large study, excellent in composition and in color, of three soldiers standing before a mass of ruins, by Major AuGUSTUS JoHN. This painting, a finished study for a large mural decoration which the artist has painted for the Canadian Government, in its simplicity and strength, but above all in its pale and reticent color, rather suggests the decorations of Puvis de Chavannes. This was one of the most notable pictures in the exhibition. Several canvases by Sir JoHN LAVEry, a painting by Mr. George Clausen, a piece of sculpture by Mr. JACOB Epstein, the only one in the collection, lithographs by Messrs. ERIC H. Kennington, Frank Brangwyn and G. Spencer Pryse, with other works by Messrs. W. B. Adeney, Alfred Bentley, John Everett, Colin W. Gill, C. J. Holmes, Bernard Meninsky, William Rothenstein, Henry Rushbury, Randolph Schwabe and E. A.Verpilleux were also shown.

\section{III}

Under the auspices of the British Government, a set of sixty'six lithographs depicting Great Britain's efforts and ideals in the war was dis, played in many parts of the United States. A number of sets were sent to this country to be exhibited and sold as propaganda. The idea originating with the artists who made these lithographs.

Artistically, the six prints by Mr. Muirhead Bone, entitled Building Ships are the most important, being most masterly in execution. Mr. ERIC KenNINGTON's set entitled Making Soldiers is also very fine indeed. Mr. Robert Nichols, an English poet, who served throughout the war, quite rightly, I think, says that Mr. KenNINGToN's drawings are wonderful portrayals of the British soldier as he is - a sober reflective being, and not a musichall humorist with a passion for being killed, as the music-halls would make him out.

Excellent, too, are the sets by Mr. Frank BrANGwyn entitled Making Sailors, by Mr. George Clausen entitled Making Guns, by Mr. C. R. W. Nevinson entitled Making Aircraft, by Mr. Charles Pears entitled Transport by Sea, by Mr. WiLliam RothensteIn entitled Work on the 
Land and by Mr. Claude Shepperson entitled Tending the Wounded. Mr. A. S. Hartrick's series bearing the legend Women's Work was not so well drawn as the others.

The above lithographs are intended to illustrate Great Britain's ef forts in the war: the second part of the exhibition sets forth some of the ideals for which she was fighting. These were all in color, with the exception of Major Augustus JoHn's lithograph entitled The Dawn. Perhaps the most beautiful in the set is Mr. Chardes H. Shannon's The Re-birth of the Arts, in which Art, unscathed, is seen rising to her feet amidst a scene of desolation. Extremely beautiful also, both in design and color, is Mr. Edmund Dulac's Poland, a Nation. The other lithographs in this set are Mr. ERnest Jackson's Defense Against Aggression-England and France-I9I4, Mr. Charles Ricketts' Italia Redenta, Mr. Frank Brangwyn's The Freedom of the Seas, Mr. William Rothenstein's The Triumph of Democracy,Mr. William Nicholson's The End of War, Mr. Maurice Greiffenhagen's The Restoration of Alsace-Lorraine to France, Mr. George Clausen's The Reconstruction of Belgium, Mr. G. MoIrA's The Restoration of Serbia and Mr. Edmund J. Sullivan's The Reign of Justice.

\section{IV}

During the first two years of the war it was almost impossible for either an artist or a photographer to get to the front. Mr. Frederic VILLIERs, one of the most famous of living war artists, having covered practically every war since the Franco-Prussian War, was refused permission to work with the British armies, but succeeded in getting permission to sketch with the French. His very accurate drawings, as a rule actually made on the spot, many times in a front-line trench, were published in The Illustrated London News. Mr. Viluiers told the writer of this book that they are the only drawings in existence depicting the first two years of the conflict, which gives them a very real value as historical records, aside from their excellent draughtsmanship. 
Artistically speaking, the British war posters are very far below the French in interest, being for the most part but garish and illy drawn commercial products, as were the American. The posters of Messrs. G. Spencer Pryse and Frank Brangwyn, whose posters some years ago in the London "Underground" attracted so much attention owing to their very great artistic appeal, are the exceptions. Captain Pryse's post. ers are true works of art and constitute some of the best lithographs of any description produced during the war. Such a poster of his as that entitled The Only Road for an Englishman, which shows a regiment of British soldiers marching through a ruined town, is not only extremely well drawn and excellent in composition and in color, but it makes a very strong emotional appeal. In addition to his posters, Captain PRYse has drawn a great many auto-lithographs, issued in proof form and possessing a very beautiful lithographic quality. The strong human appeal in all of these lithographs is irresistible and accounts in large part for their great popularity; however, the artistic appeal which they make is a real one, and theyare quitedifferent from the story-telling pictures which one associates with the Royal Academy. Mr. Brangwyn's posters to encourage enlistment in the navy are very vigorous compositions, full of energy and displaying a keen sense for the dramatic.

Major Charles Pears has painted a series of extremely fine marine paintings, many of them being of camouflaged ships. Mr. GLYN PHILPOT has painted portraits of four of the British admirals, while Mr. Francis DoDD has made pencil drawings, colored with water'color, of twelve: these latter are beautifully drawn.

In touching upon the war pictures which have been made by British artists, one must certainly not neglect to mention the humorous and racy sketches made at the front by Captain Bruce Bairnsfather. His three favorite characters, who appear in most of his drawings, Old Bill, Alf and Bert, were great favorites among both the soldiers at the front and the people at home. These three famous characters have had a very successful play written around their exploits. 


\section{$\mathrm{V}$}

The Canadian War Memorials Funa was founded in order that every phase of Canada's operations, both in Canadian training camps and on the battlefields of France, might be properly recorded.

The idea for this form of memorial originated with Lord Rothermere, former British Air Minister and Lord Beaverbrook, head of the Canadian War Records Office and former Minister of Information. Mr. Paul G. Konody was appointed art director, which position he has held since the inception of the Memorial, in the summer of I9I7.

In organizing the scheme, as is pointed out in the foreword to the catalogue of that portion of the pictures which was shown in London and in New York [I9I9],"the committee throughout endeavored to do equal justice to the claims of history and of art. Historical accuracy has been secured by the timely dispatch of a band of distinguished artists to the fighting front. To ensure artistic success the committee worked out a schedule of subjects embracing every sphere of Canadian war preparation and war activity exemplified by typical scenes, each one being entrusted to the artist whose past achievements pointed mostclearly to his ability to do full justice to his task. These artists were selected in the most catholic spirit, to represent every school and group. This series of decorative panels was thought out in connection with an architectural scheme which is to form a suitable and imposing framework for the pictures, so that they will present themselves as an impressive ensemble in orderly sequence. Around this nucleus of vast decorative panels has been built up a comprehensive collection of minor paintings, drawings and engravings of war subjects, portraits of generals, statesmen and Canadian V. C.'s, works of sculpture, and a historical section of early English paintings and engravings, directly connected with Canadian history."

Among the latter paintings, it is interesting to note, are Romney's portrait of Joseph Brant, the celebrated "sachem" of the Mohawk Indians, Reynolds's portrait of Sir Jeffrey Amherst, Lawrence's portrait of Sir [140] 
Alexander Mackenzie and West's painting entitled The Death of Wolfe.

Majors Augustus John, D. Y. Cameron, Richard Jack and J. KerR LAWson were the first artists to be sent to the front by the Canadian War Memorials. Major JoHs's painting, which will dominate the mag' nificent building which is to be erected in Ottawa to house this collection, is a large decorative canvas measuring forty by ten feet. $\mathrm{Mr}$. Konody describes it in the following words: "JoHs's art is always synthetic. He is not an illustrator. He goes for the typical, not the incidental. His subject is not any particular episode, but a summary of all he has seen, of all that has stirred his imagination and his sympathy during his five months at the front. His picture may be described as an epitome of modern war." Major CAMERON painted an impression of the featureless plains of Flanders and Major JACK pictures of the second battle of Ypres and of the attack made on Vimy Ridge on the gth of April, I917. Major LAwson showed in his paintings the ruins of Ypres and Arras.

Mr. C. R.W. Nevinson painted one of the exploits of Major Bishop, Canada's greatest airman, and a series of four panels entitled The Roads of France, illustrating the progress of the fighting force from the base to the front line. Mr. A. J. MunNIngs painted a series of fifty small paintings of Canadian cavalry and lumbermen, pictures of marked excellence and most spirited.Other important pictures of events connected with the war were painted by Lieutenants A. Y. JACKson and ALGRRNon TALMAge, GunNer W. Roberts, Lieutenant Paul Nash, and Mr. Leonard RichMOND, to mention but a few of the fifty or more other artists engaged in this work. Portraits of military and civil personages of distinction were painted by Mr. Charles H. Shannon, Major Ambrose McEvoy, Mr. Harold KNIGHT, Sir William Orpen, and numerous other portrait painters of great reputation.

In addition to the pictures painted in the fighting zone, Canada also possesses a valuable series of paintings and drawings showing the making [I $4 \mathrm{I}$ ] 
of the soldier in Canada and all the other activities at home. Mr. ARTHur Lismer has painted records of things going on at Halifax: Mine sweeping, convoying, patrolling and harbor defense. Miss MABEL MAY went to the murition works in Montreal, wherewomen and girls labored unceasingly. Mr. ManLy MacDonald chose woman's work on the land as his subject. Mr. Francis H. Johnston went to the Toronto Fly, ing Schools and Mr. R. F. GAGEN painted a shipbuilding picture in Toronto Bay. Lieutenant-Commander Norman WiLkinson painted a spirited canvas showing the great fleet which carried the First Canadian Division across to England at the outbreak of the war. I have merely chosen a few examples to illustrate the interesting and comprehensive manner in which this side of the work was accomplished.

Sculpture, it should be noted, was executed by Captain F. Derwent Wood and M. I. Mestrovic.

The following comments on the Canadian War Memorials, and on war memorials in general, are taken from an anonymous article published in Canada in Khaki. I am so in accord with the writer's views on this subject that I have ventured to quote him at some length:

"The idea of an artistic war memorial is generally connected with a winged and laurel-crowned confection in marble and bronze, erected on some prominent site for the edification or derision, as the case may be, of future generations. Or, if it takes a pictorial form, it is apt to be a series of unconvincing, melodramatic illustrations, more or less fanciful, of famous episodes or individual acts of heroism, that are of little artistic and absolutely no documentary or historical value. Who can pass through the endless galleries of battle pictures at Versailles without experiencing a sense of invincible boredom? A war memorial of this kind, if it is to be of lasting value, if it is to teach future generations, to stir their imagination, to stimulate their patriotic feeling, must be a thrilling record of facts, based on personal experience.

"If a pictorial record of this greatest of all wars is to be of permanent value, it must be created from actual impressions whilst they are

$$
[142]
$$


fresh on the mind, whilst emotions and passions and enthusiasms are at their highest. A 'posthumous' war picture is as valueless as a posthumous portrait. ... Art remains to teach posterity of the glorious part of the race, and to keep alive the flame of patriotism. Our whole knowledge of civilizations that have vanished long since-Egypt, Babylonia, Chaldaea, and so forth-is derived from the scanty artistic records that have been saved from the destruction of Time and War. The visual evidence of one fragment of art teaches us more, and more tellingly and rapidly, than whole volumes of erudition."

Australia also had her official artists to depict her achievements, as well as men in the ranks who recorded their impressions. These artists, who worked in Palestine and Egypt, as well as in France, made many hundred paintings and drawings of marked excellence. Some of the best of these pictures are by Lieutenants F. R. Crozier, G. W. LAmbert, A. StreEton and S. J. LAMORNA BiRCH. Lieutenant LAMBERT's paintings of the tragedies attending the Gallipoli campaign are particularly well painted. 



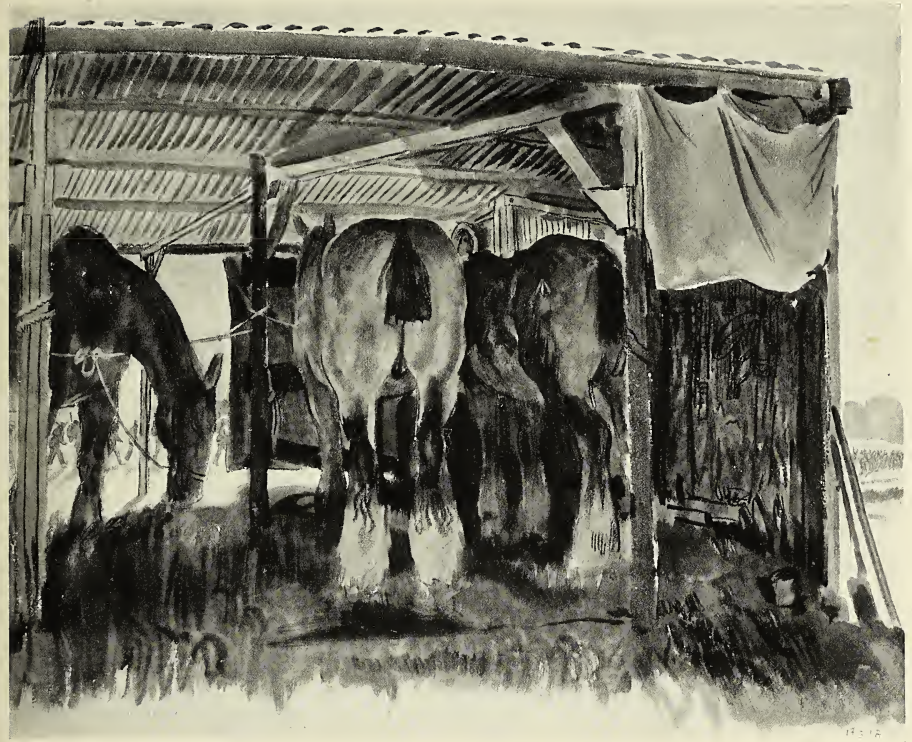

WILLIAM ORPEN

Horses Near Aubigny 



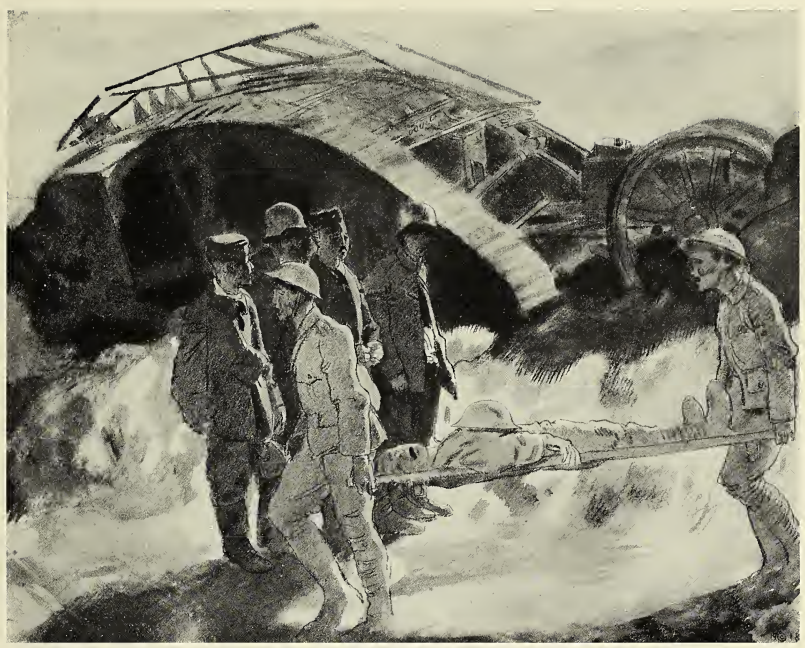

WILLIAM ORPEN

Bringing in a Wounded Tommy 



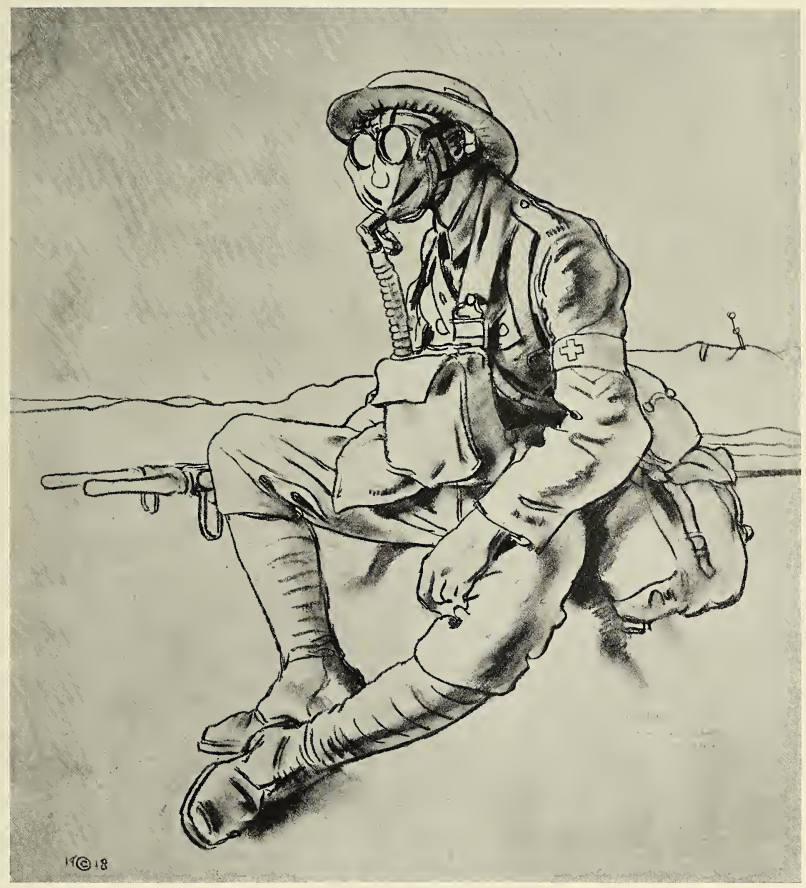

WILLIAM ORPEN

The Gas Mask 



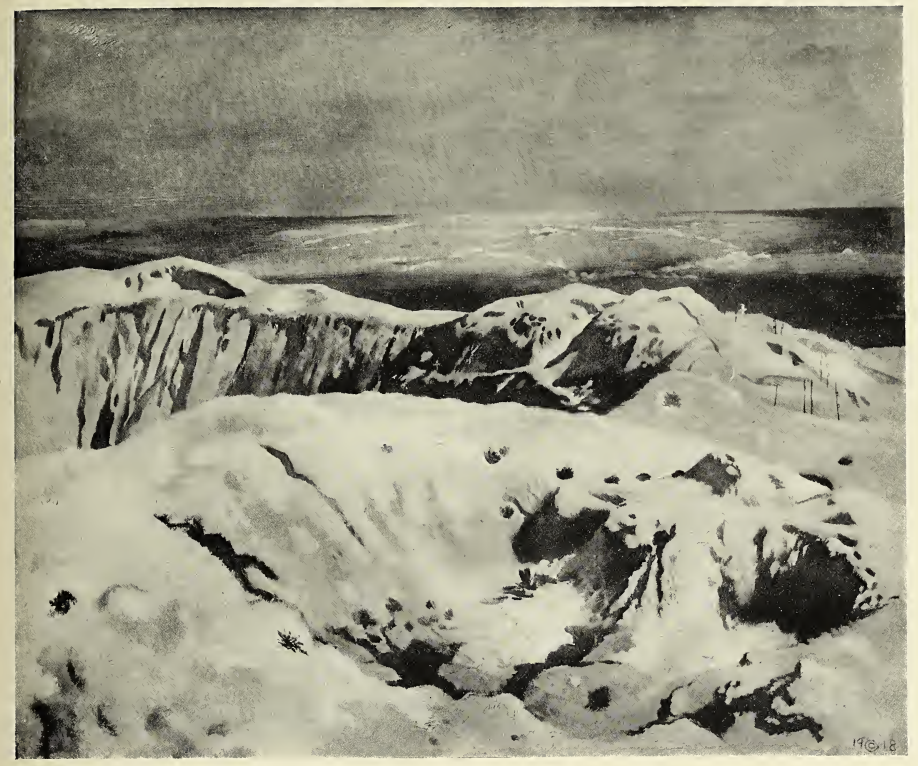

WILLIAM ORPEN

The Big Crater, No. 2 



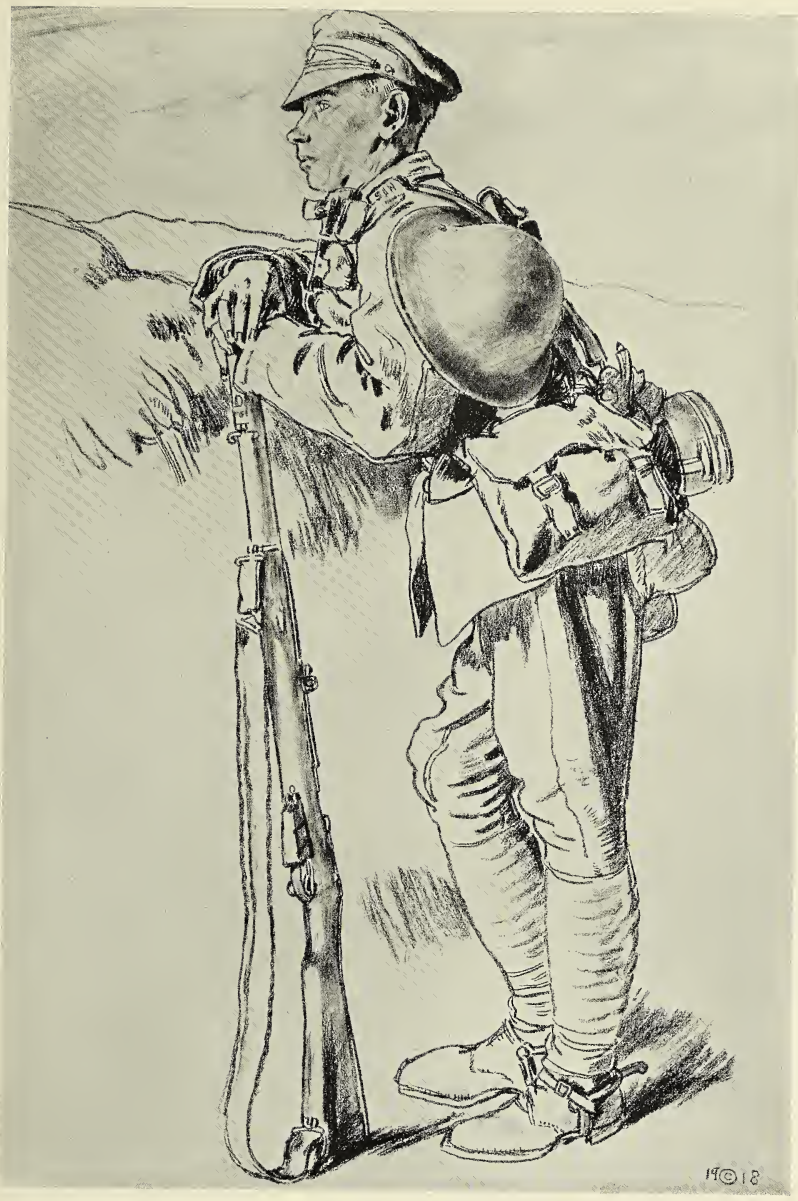

WILLIAM ORPEN

South Irish Horse 



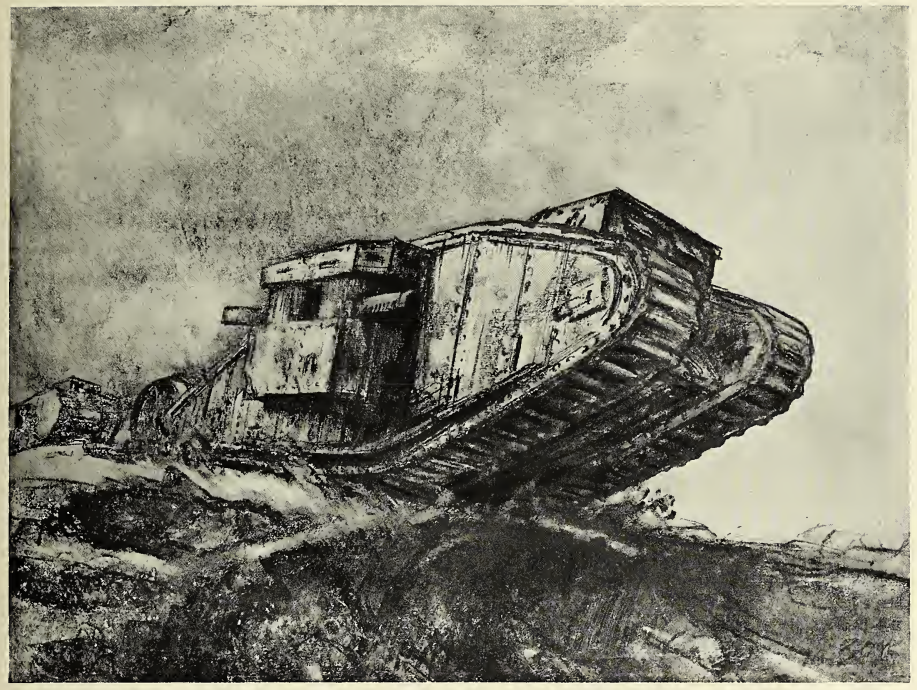

MUIRHEAD BONE

A British Tank 



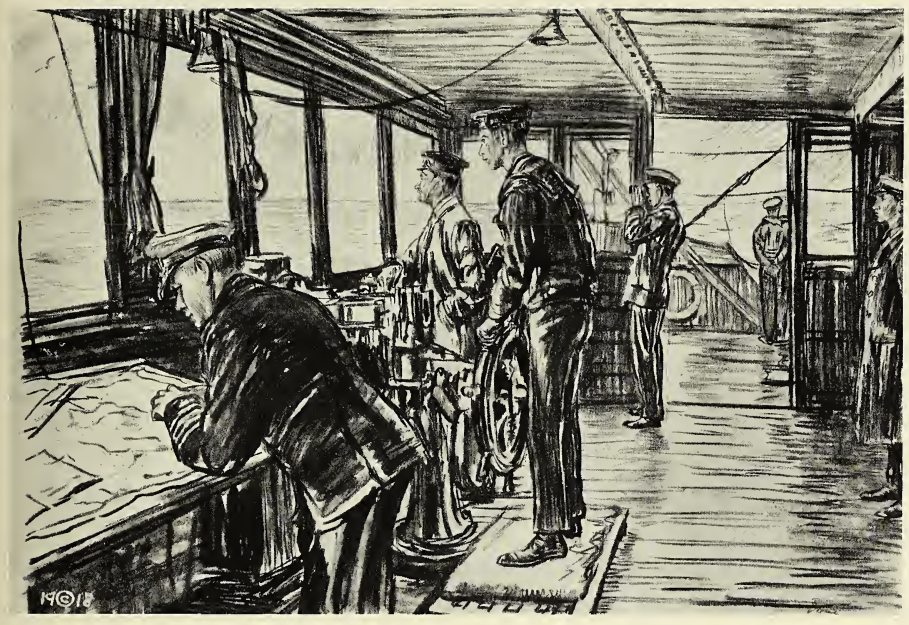

MUIRHEAD BONE

The Bridge of a British Merchant Ship at Sea 



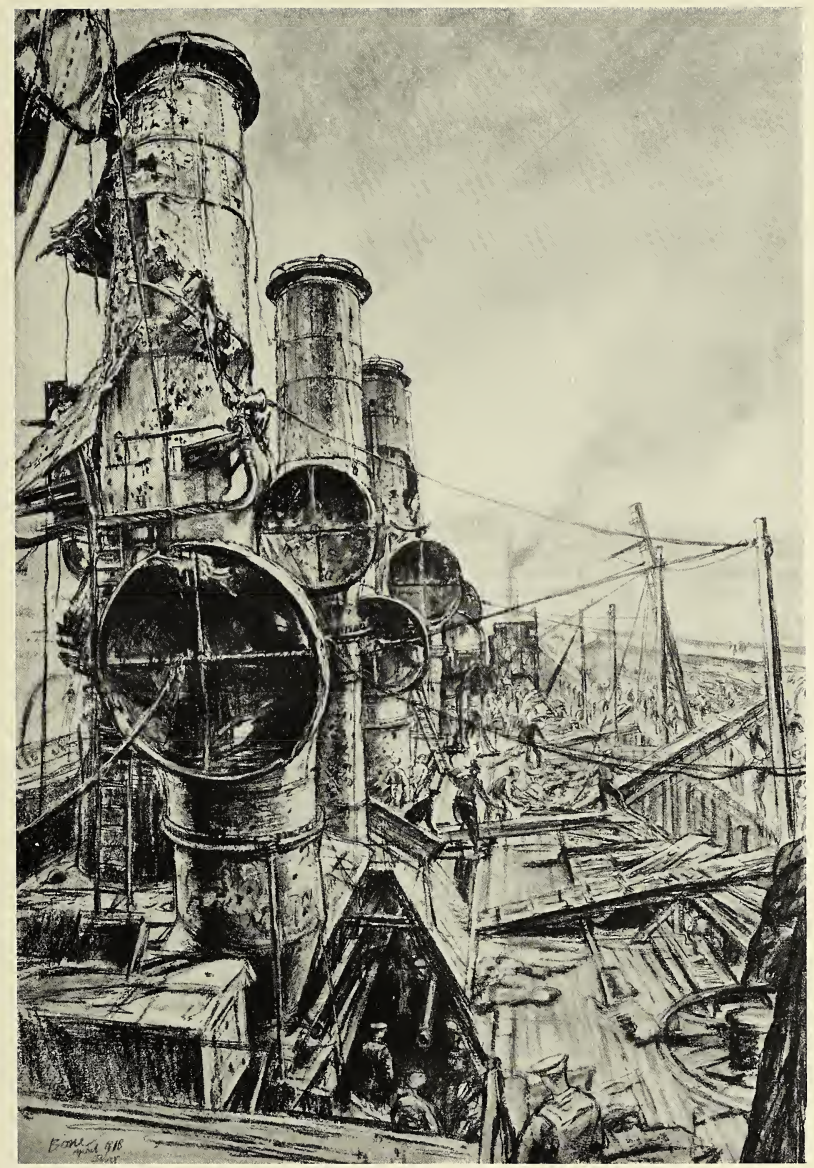

MUIRHEAD BONE

H. M. S. Vindictive after Zeebrugge 



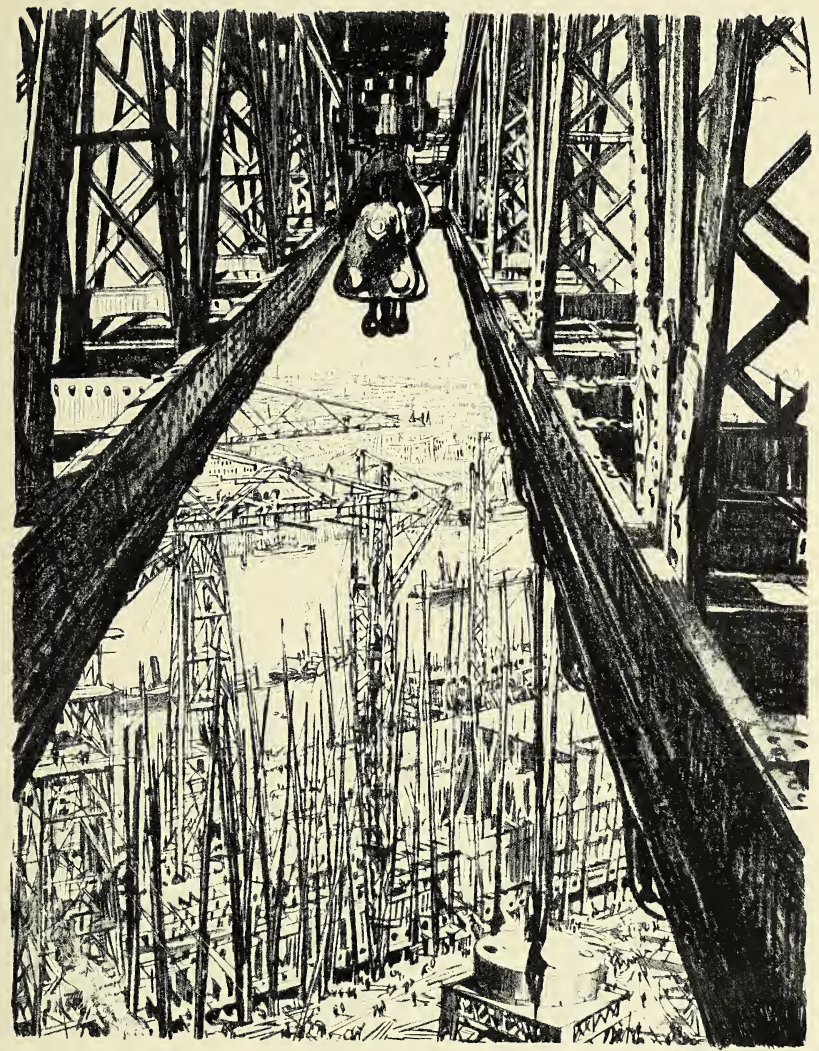

MUIRHEAD BONE

A Shipyard Scene 



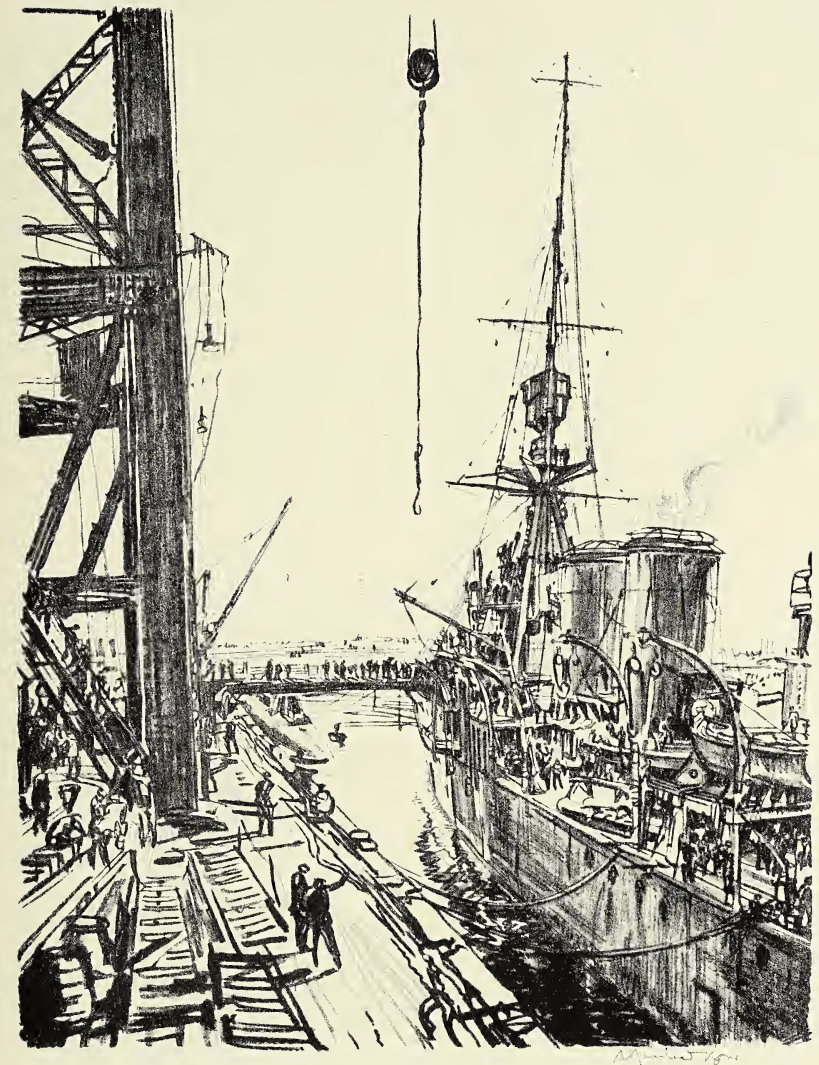

MUIRHEAD BONE

Ready for Sea 



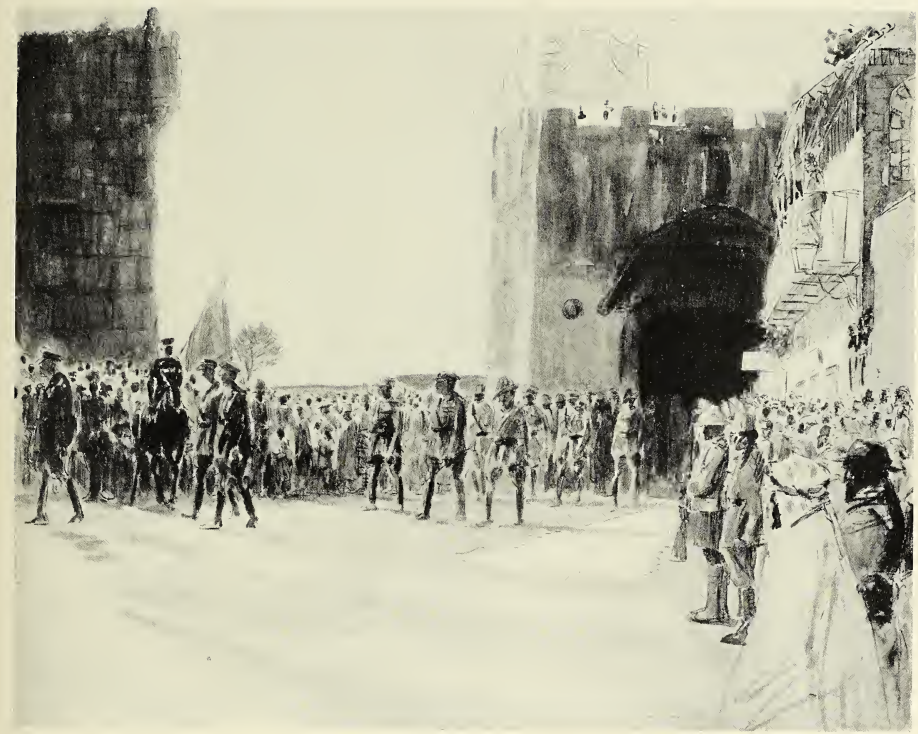

JAMES McBEY

Entry of the Allies into Jerusalem 



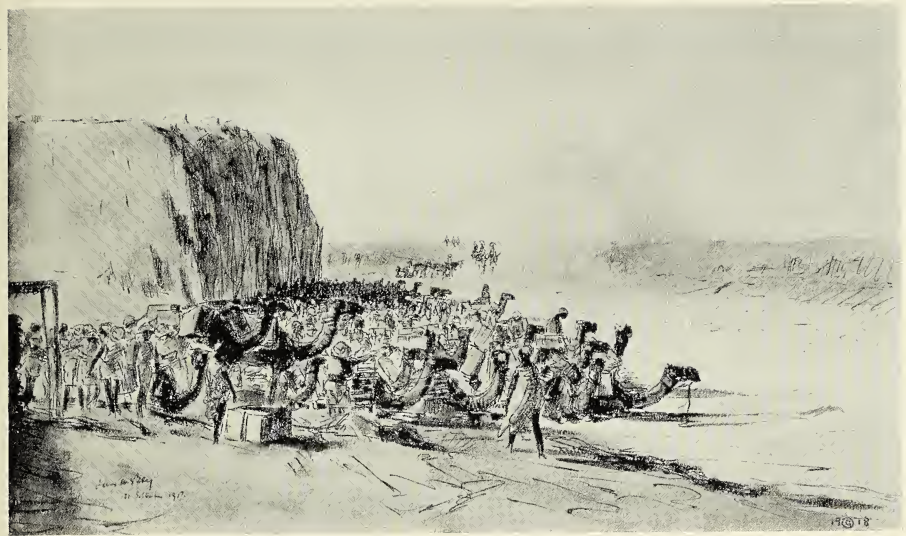

JAMES McBEY

Water Transport 



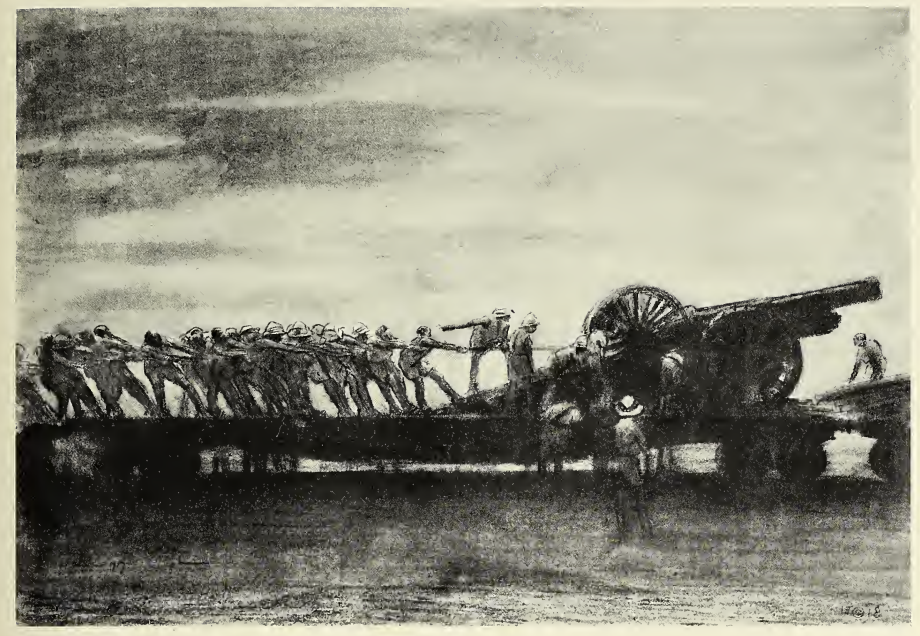

JAMES McBEY

Detraining a Howitzer by Moonlight 



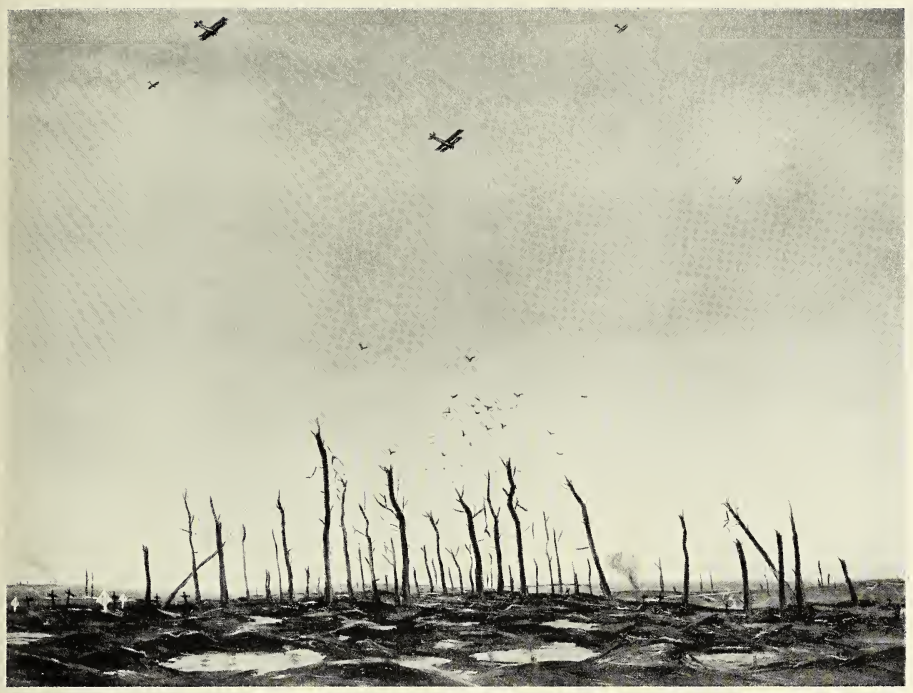

C. R. W. NEVINSON

That Cursed Wood 



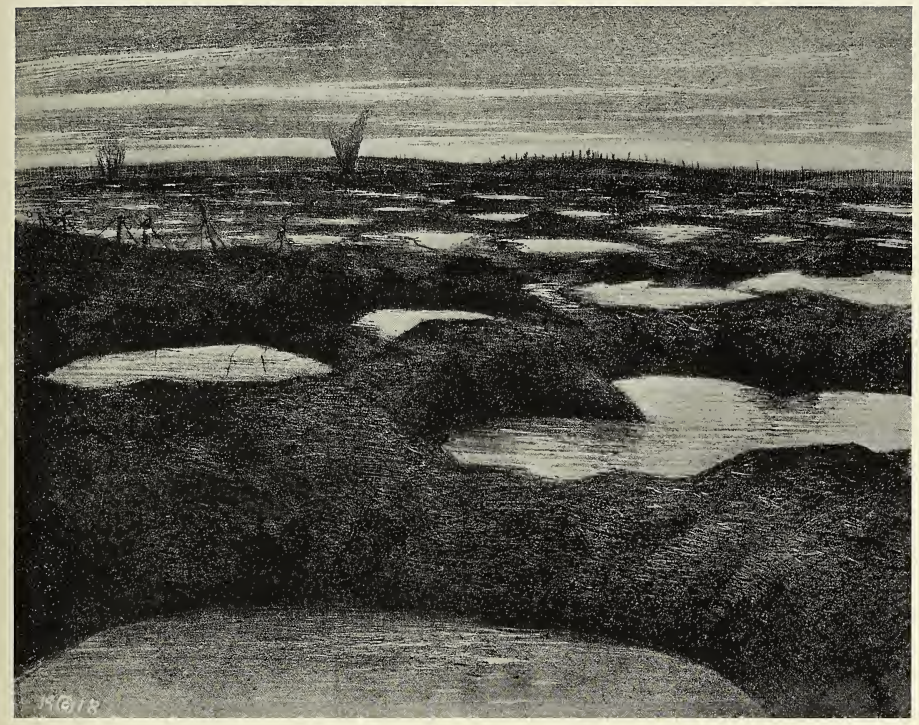

C. R. W. NEVINSON

After a Push 



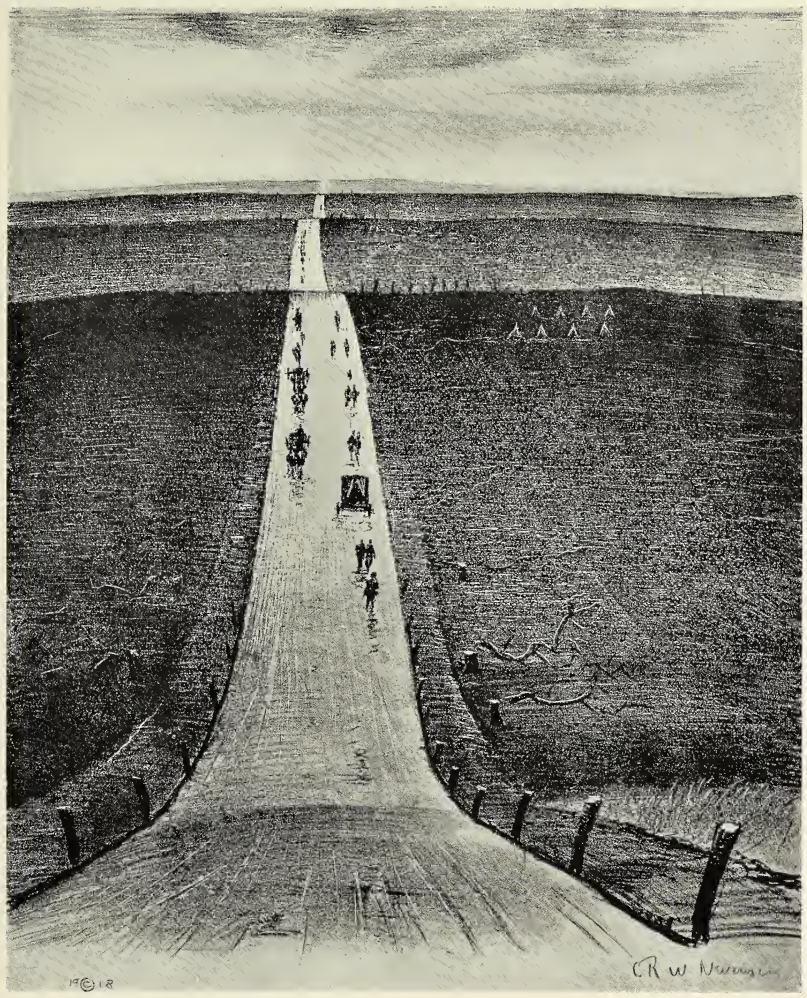

C. R. W. NEVINSON

The Road from Arras to Bapaume 



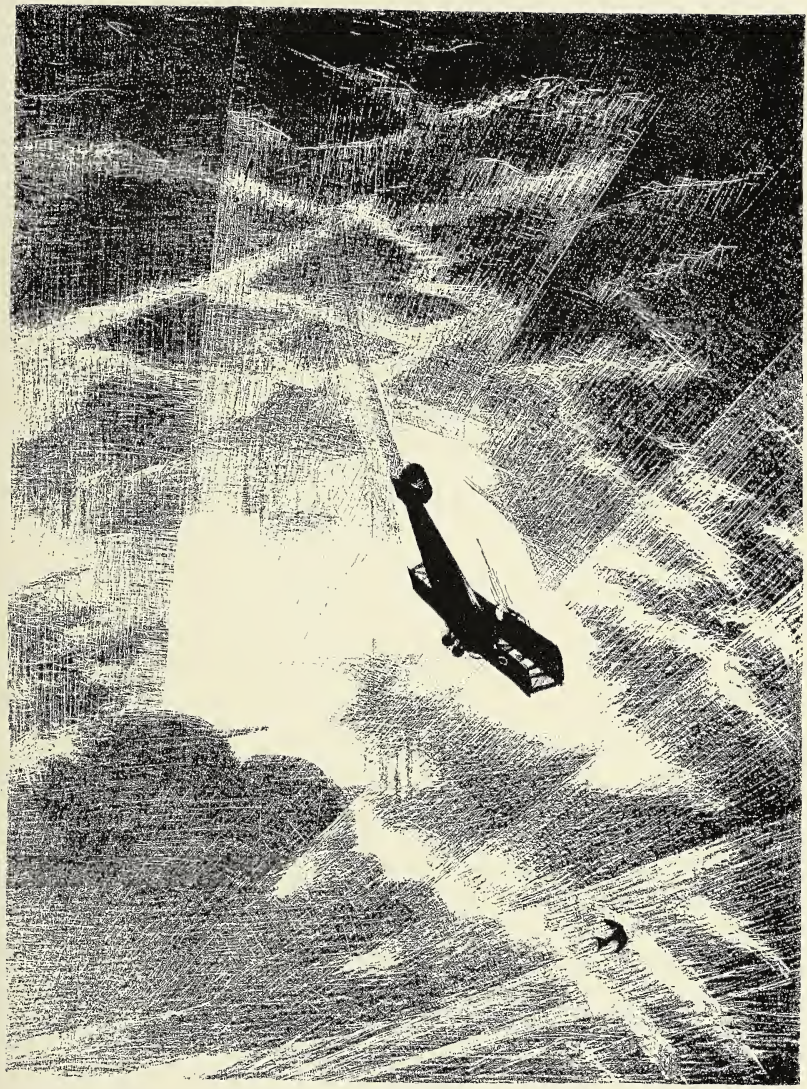

C. R. W. NEVINSON

Swooping on a Taube 



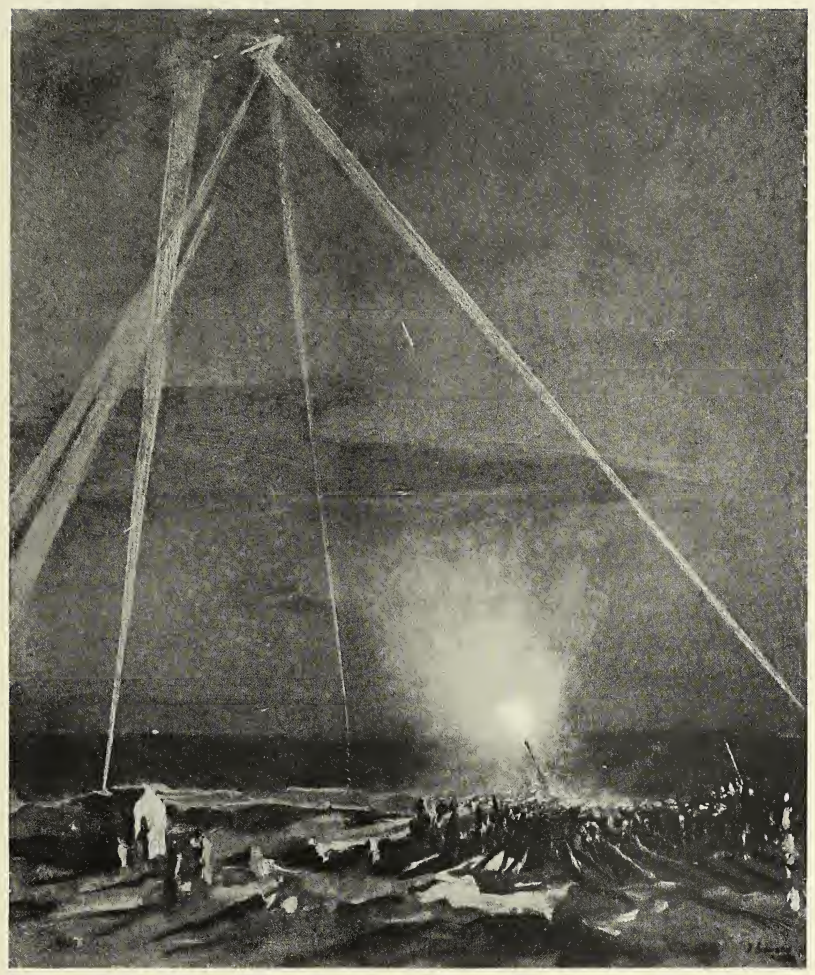

JOHN LAVERY

A Coast Defense 



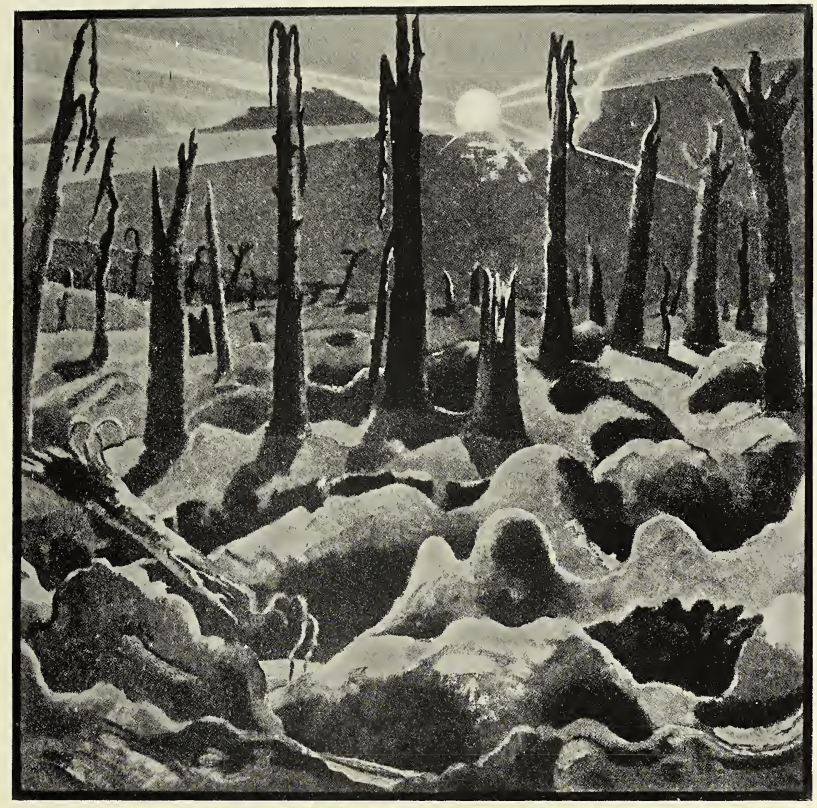

PAUL NASH

Sunrise: Inverness Copse 



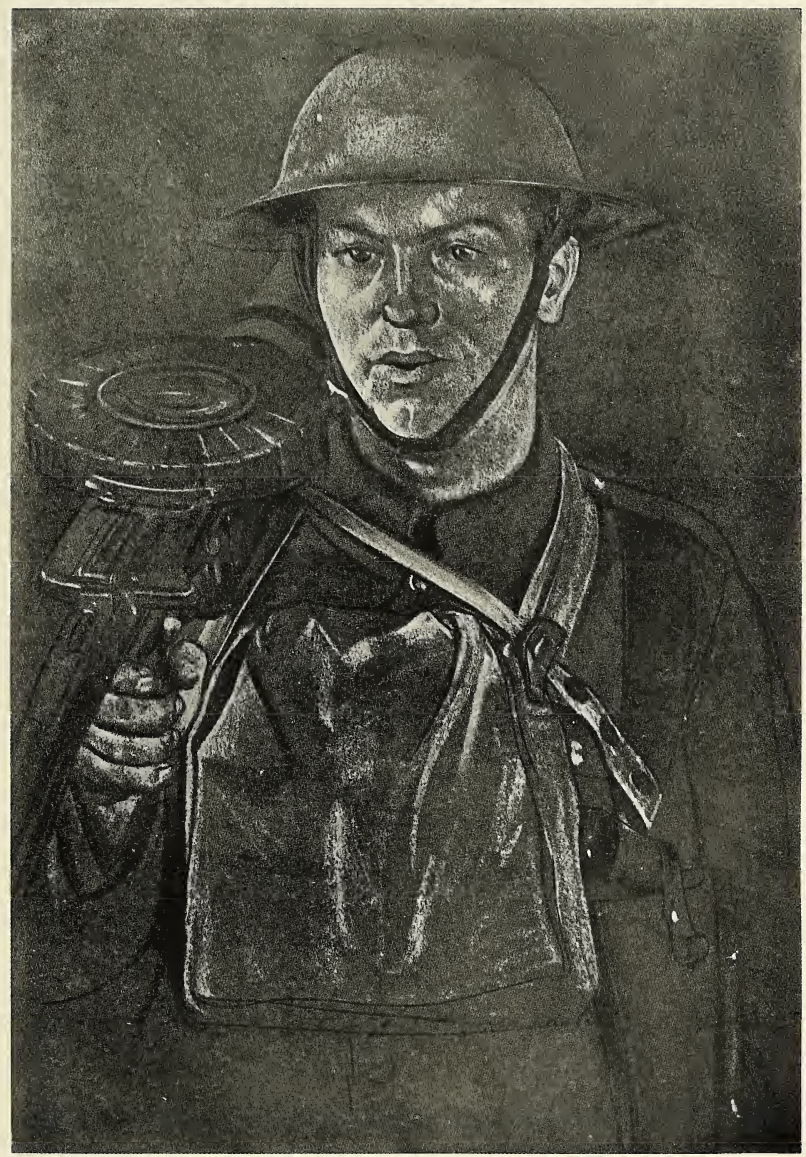

ERIC KENNINGTON

A Lewis Gunner of a Yorkshire Regiment 



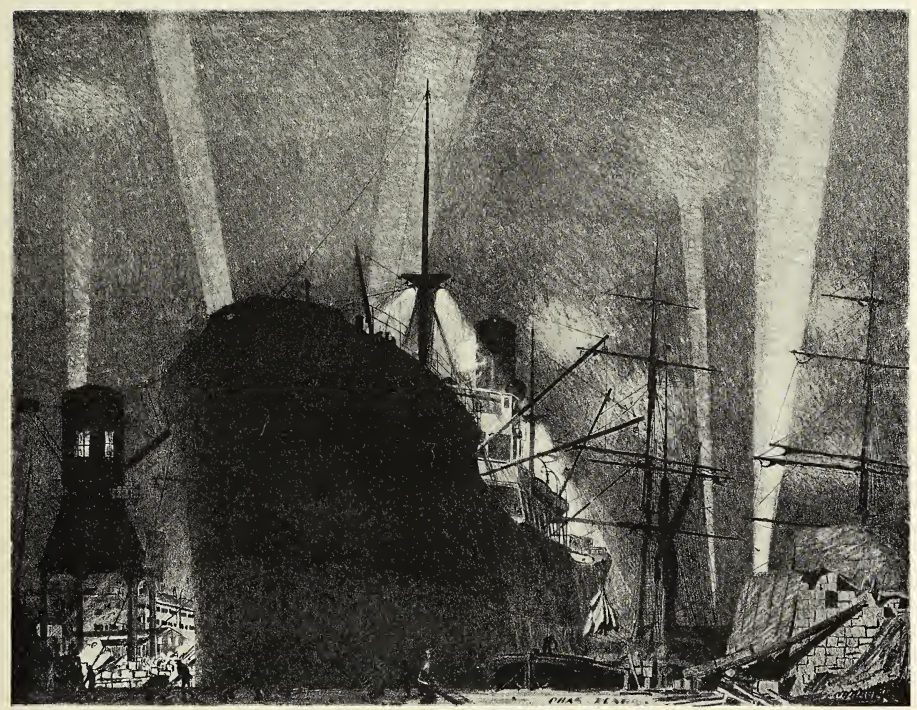

CHARLES PEARS

Maintaining Oversea Forces 



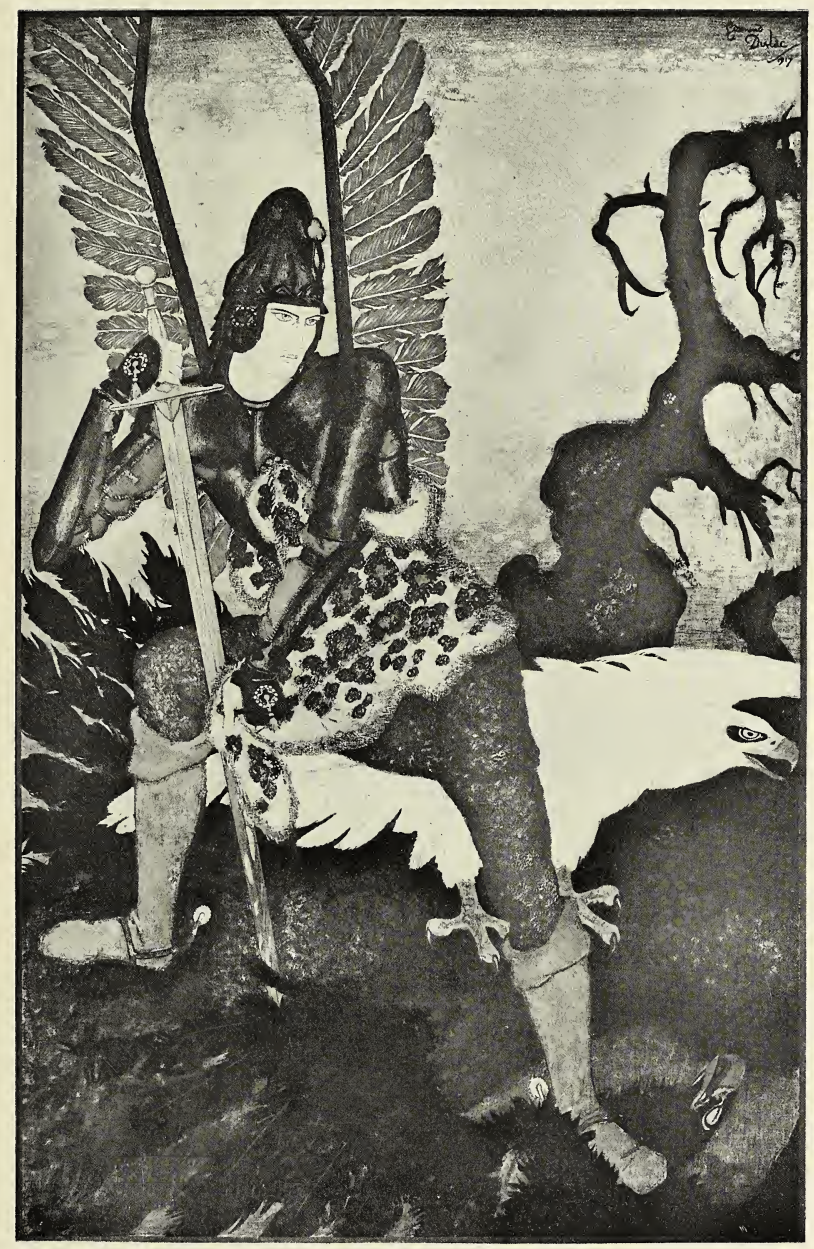

EDMUND DULAC

Poland, A Nation 



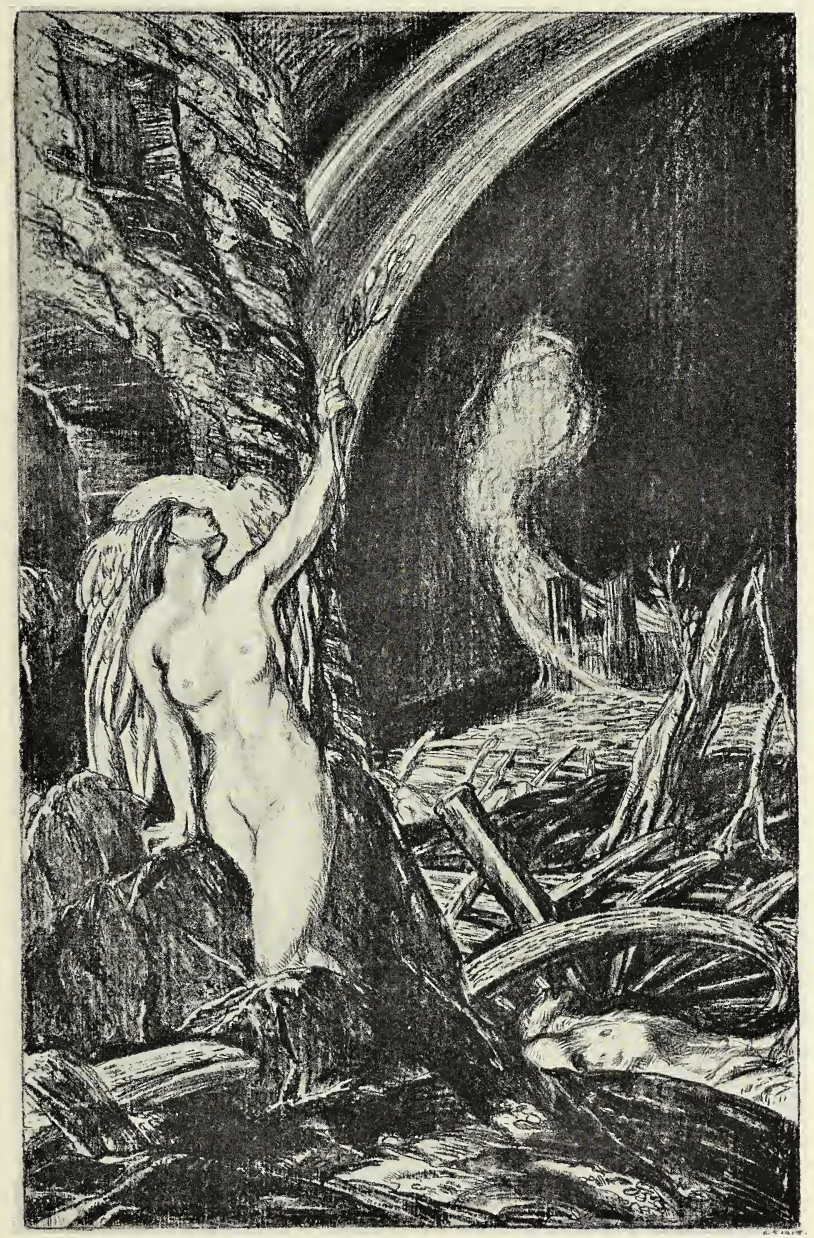

CHARLES H. SHANNON

The Re-birth of the Arts 



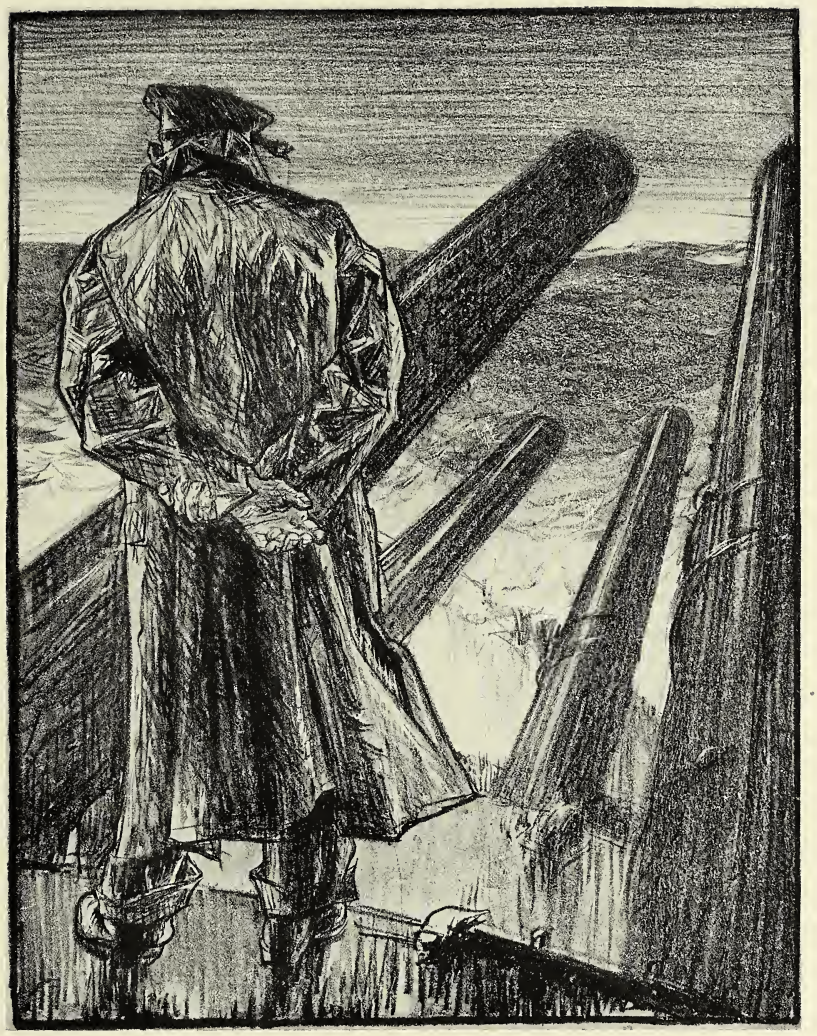

FRANK BRANGWYN

The Lookout 



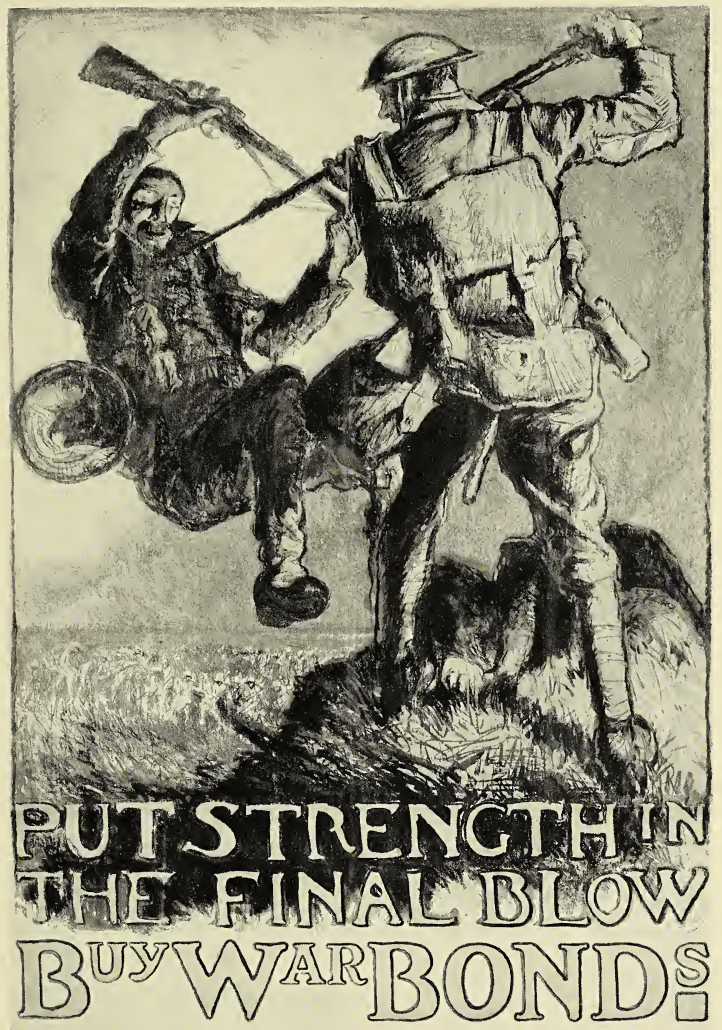

FRANK BRANGWYN

Put Strength in the Final Blow 


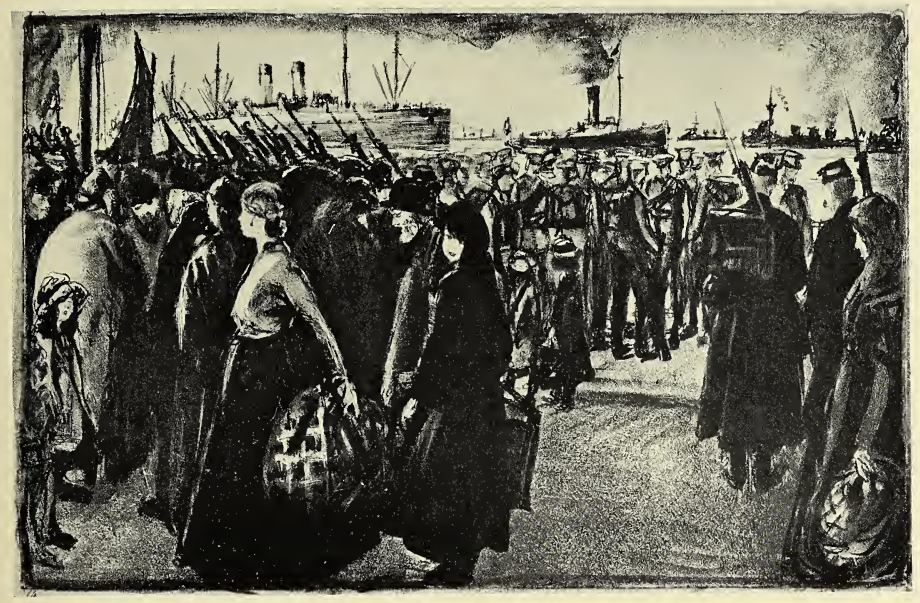

G. SPENCER PRYSE

The Fall of Ostend 



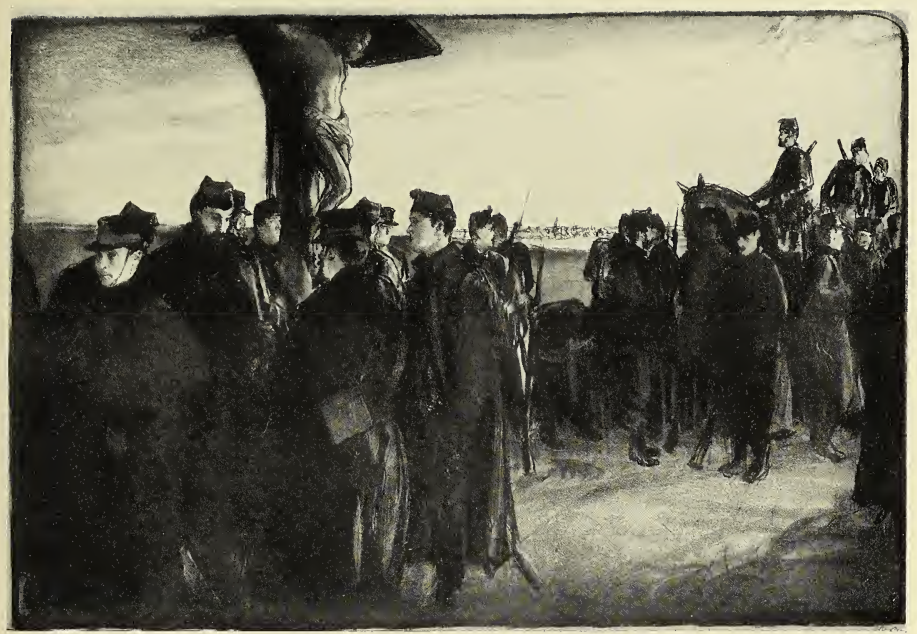

G. SPENCER PRYSE

The Wayside Crucifix - Belgium, 1914 



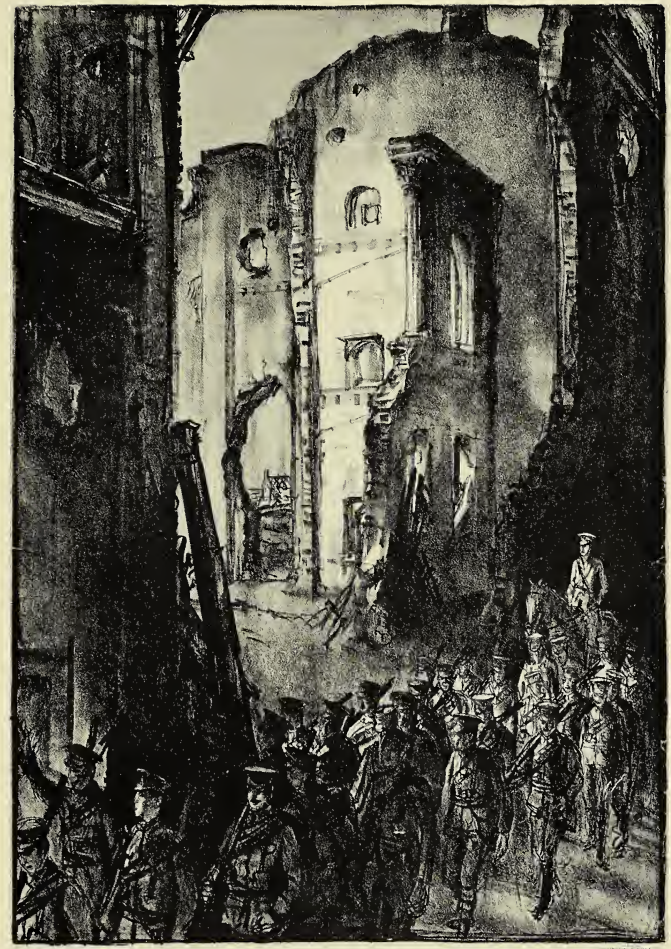

Through Dackness
tolight
FOR AN EN AN ROISHMAN

G. SPENCER PRYSE

The Only Road for an Englishman 



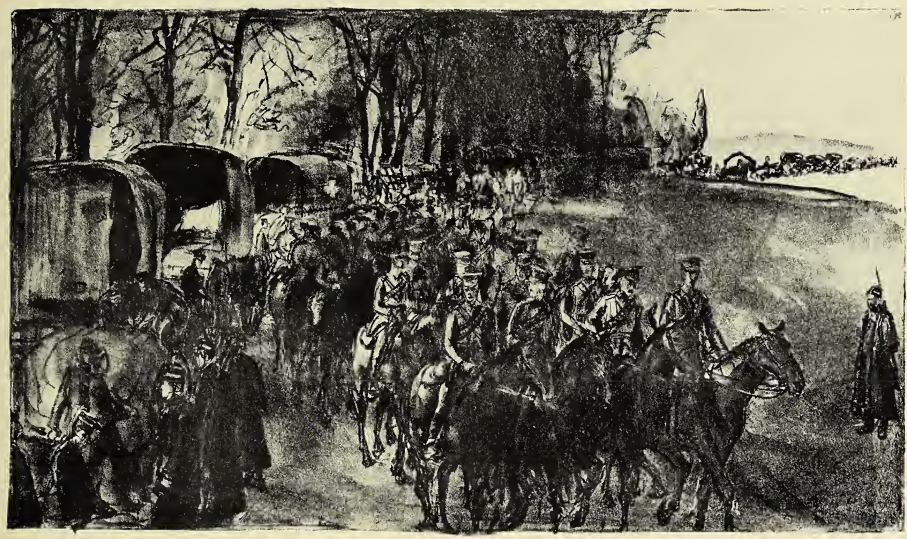

G. SPENCER PRYSE

The Retreat of the Seventh Division and Third Cavalry on Ypres 



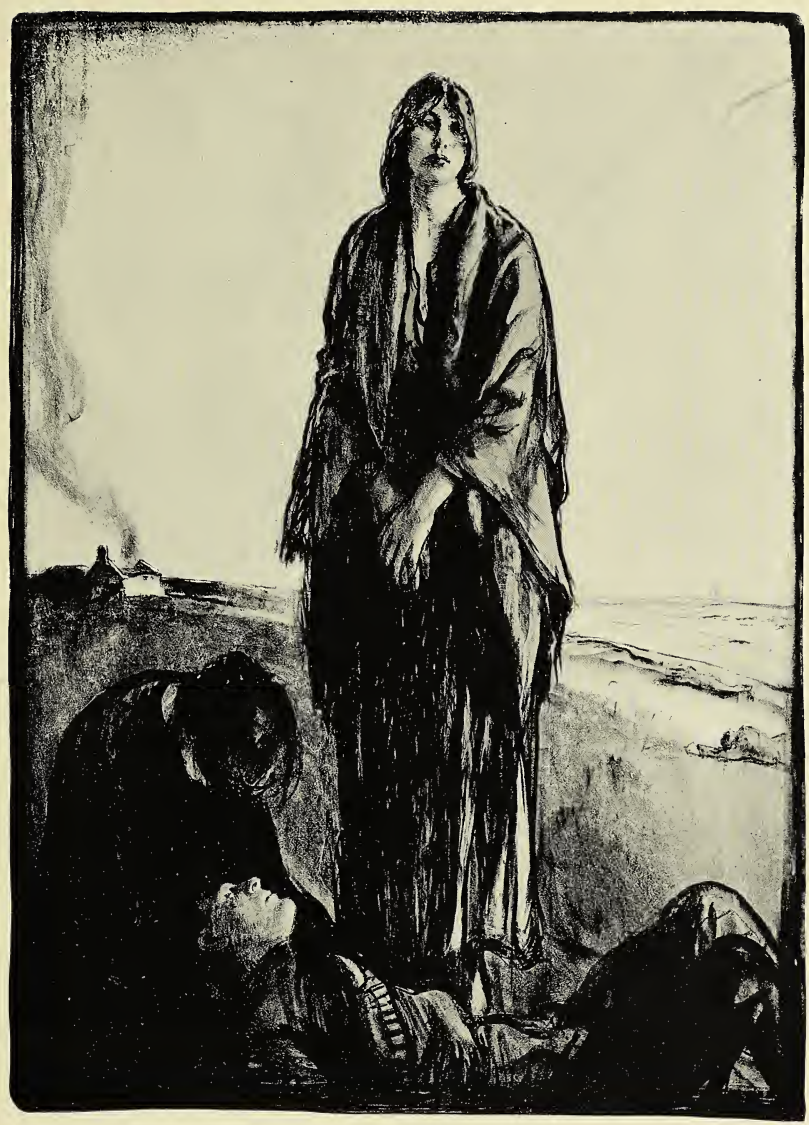

G. SPENCER PRYSE

Belgium, 1914 



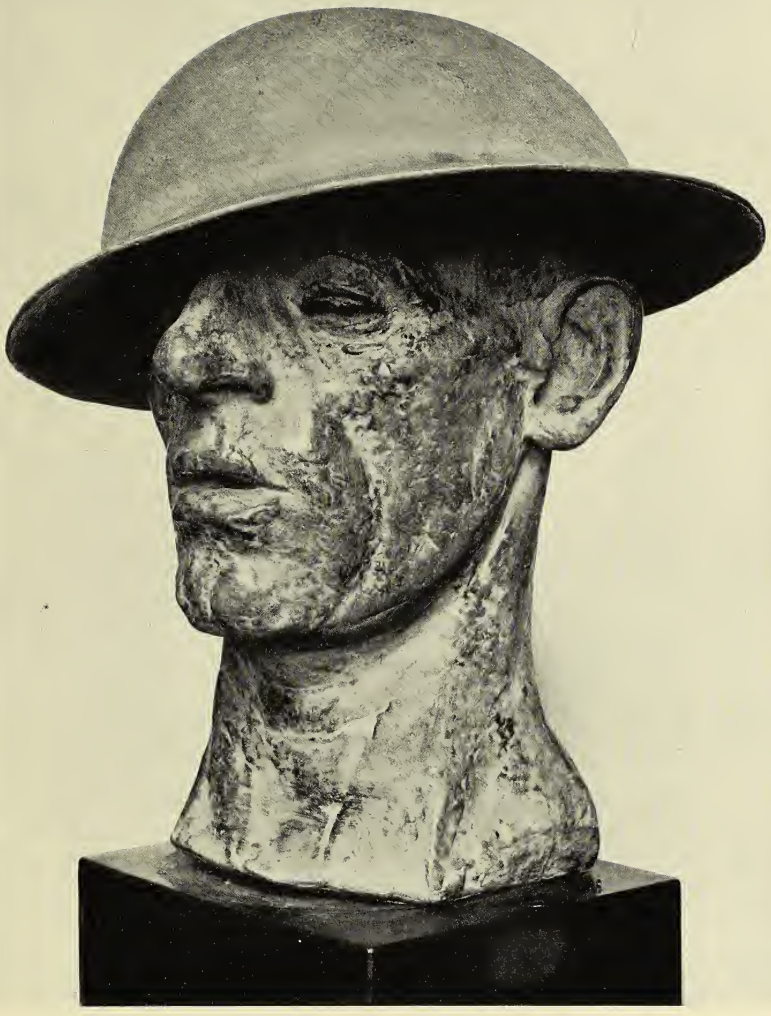

JACOB EPSTEIN

The Tin Hat 



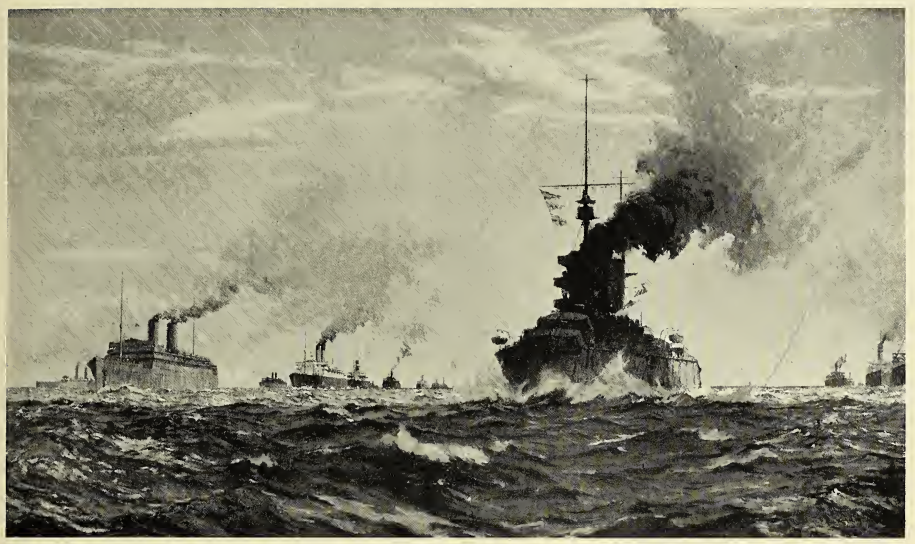

NORMAN WILKINSON

Canada's Answer 



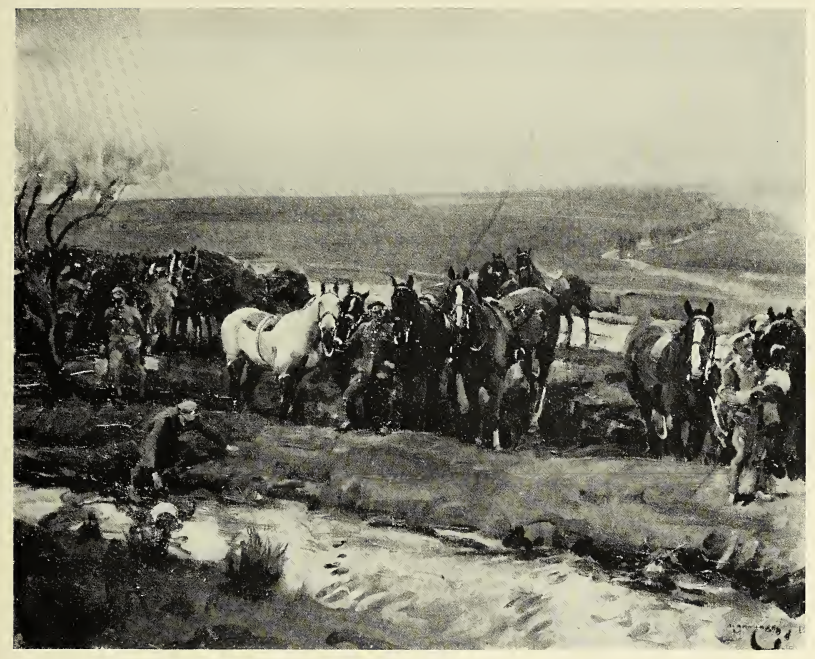

A. J. MUNNINGS

Horses Watering near Domart 



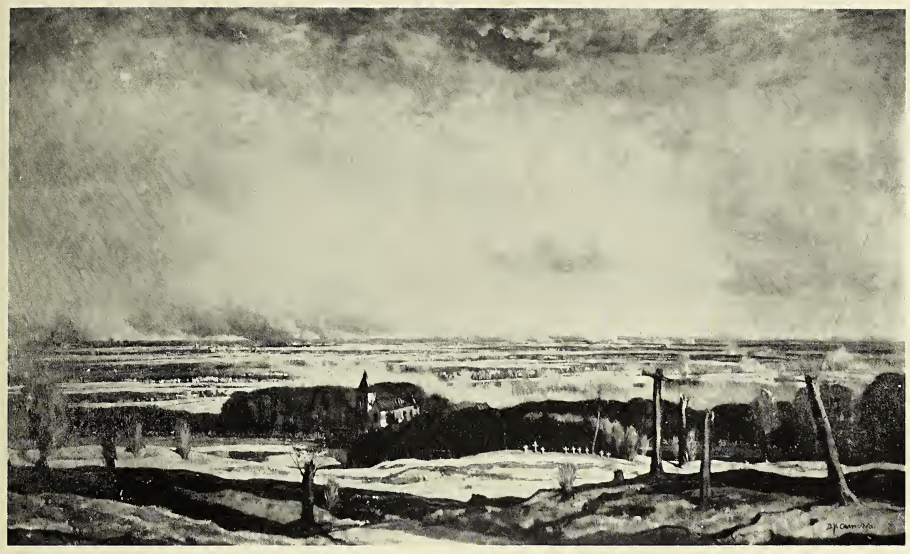

D. Y. CAMERON

Flanders from Kemmel 



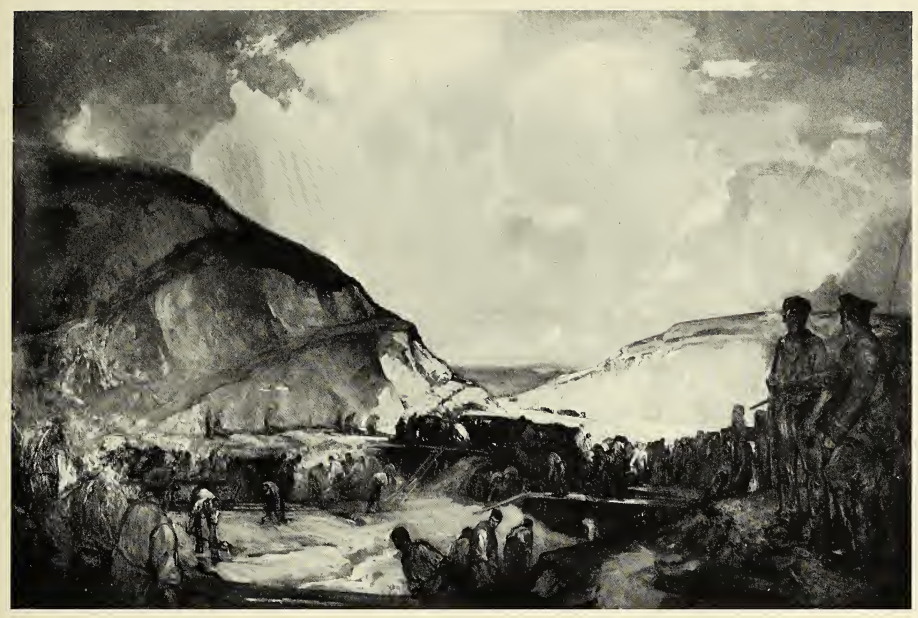

LEONARD RICHMOND

Canadian Railway Construction in France 



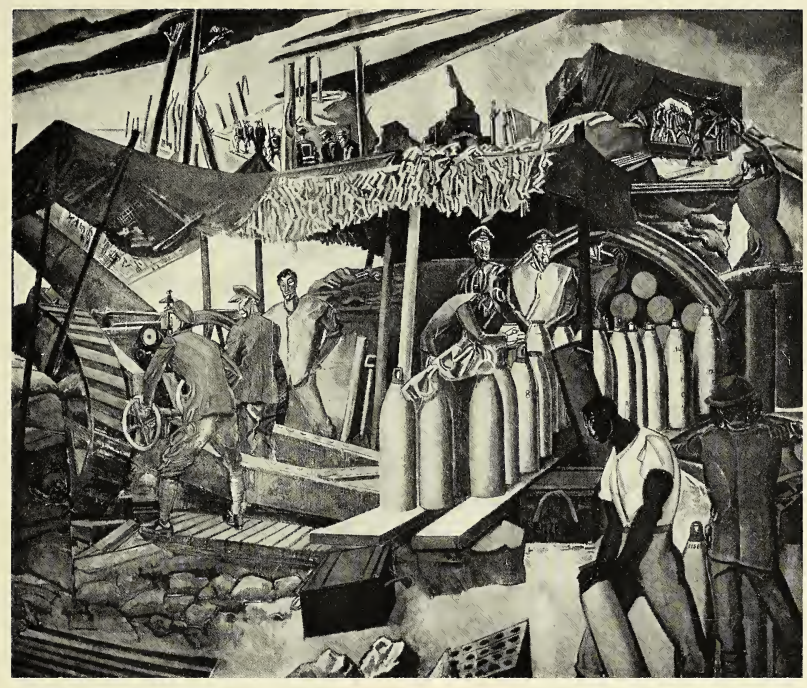

P. WYNDHAM LEWIS

Canadian Gunpit 


FRANCE 


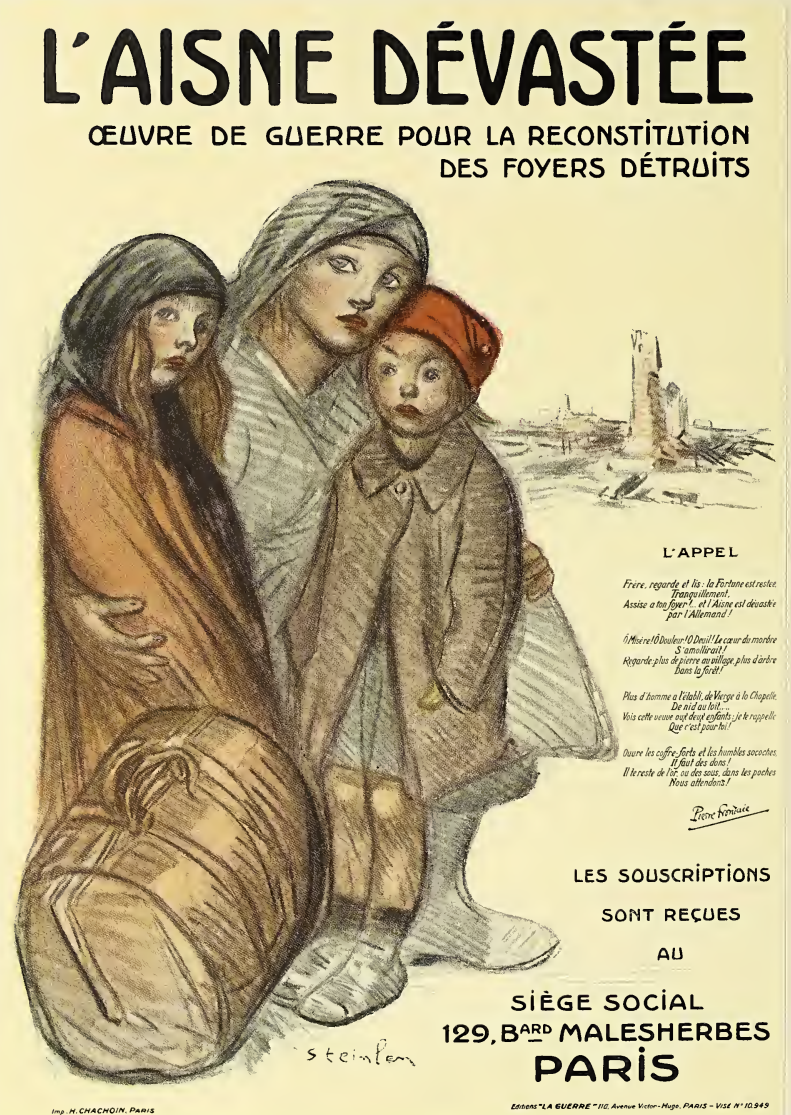

TH. A. STEINLEN

L'Aisne Dévastée 


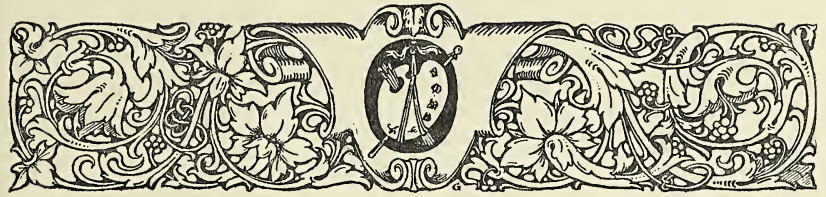

\section{CHAPTER THREE}

FRANCE

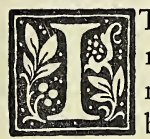

Twas in France that the lithograph first became a recognized medium for artistic expression. Géricault and Delacroix made many strong drawings, to be followed in the thirties by the great Daumier, a marvellous draughtsman and the king of caricaturists. In the sixties notable lithographs were made by Manet, Barye and Millet. The most perfect expressions of Fantin-Latour's sensitive art are to be found in his lithographs, enchanting prints which rank with the masterpieces of the art. In many cases Fantin first drew his lithograph and from it made his painting, the lithograph invariably being the more spontaneous and charming. Later came the penetrating lithographs of Toulouse-Lautrec, who was another master, and one who successfully introduced color into his prints, as well as Degas, whose lithographs only became generally known when his collections were dispersed in Paris, shortly after his death. MM. Forain and STRIN LEN, the greatest draughtsmen in France to-day, are doing much of their finest work on the lithographic stone.

Since the artistic possibilities of the lithograph were thus so splendidly developed in France, it is not surprising to find that so many of her artists choose the lithograph as their medium for recording the events of the Great War. As a matter of fact, the most artistic and important pictorial records made in France are to be found in her posters and in the powerful lithographs in black and white by MM. STEIN - 
LEN, ForaIn and LuCIEN Jonas. I believe these lithographs to be greater works of art than the drawings and paintings by her official artists, for in an inimitable and masterly fashion they express the soul of the great French nation and put before us in a vivid manner her undaunted courage and devotion to la Patrie.

\section{II}

The drawings and etchings of M. STEINLEN possess the very scent and flavor of Paris. They are as typically Parisian as the drawings of Row. landson are essentially English and the pictures of Goya reek of the soil of Spain.

With much pertinence M. STEINLEN has been called the Millet of the streets, for in his studies of the toiling workers of Paris, of the artists and of the destitute, we find the same understanding that we find in the peasants of Millet. In STEINLEN we see always a profound sympathy with suffering humanity and tenderness towards the oppressed and unfortunate, learned through a long familiarity with the inhabitants of the various poorer quarters of Paris.

M. SteInLEN's artistic output has been enormous: his pencil is nearly as active as was Daumier's. And always this gifted pencil has been wielded on the side of justice; many times has he fought battles for the oppressed. In his history of painting, Major Haldane Macfall says that M.STEINLEN is "one of the giants of his age, a man who has bettered the world, lifted his generation, and brought honor to his great people." His drawings for Gil Blas and illustrations for the books of Coppé, de Maupassant, Anatole France, Bruant, the cabaret singer, and chansons entitled Dans la Route, as well as for many other publications, are numbered by the thousand. Extremely beautiful are his lithographs for Chanson de Montmartre and full of character his Des Chats; no one has drawn a cat as well as M. SteinLen.

With such an artistic equipment and with such a profound sympathy with suffering humanity, it was but natural that M.STEINLEN should throw himself heart and soul into depicting events connected with the

$$
[222]
$$


terrible war. He more than rose to the occasion and in a succession of posters, drawings, lithographs and etchings he has preserved for posterity a magnificent and unequalled record of the nobility of character and bravery displayed by the French race, as well as the appalling distress wrought upon that valiant people. With profound understanding and sympathy he has gone, sketch-book in hand, to the railway station where the wounded are arriving, he has gone to the devastated town, he has stood by the roadside as the soldiers marched by. An etching shows us several badly wounded men being carried from the battlefield under fire: it is called The Escape from Hell. A lithograph has for its subject a procession of old people and little children and babies leaving a German jail. Another lithograph is of a group of soldiers lustily singing as they march down the road.

\section{III}

M. Forain is as caustic and unrelenting in his realism as was Degas. In addition, he is a satirist and one that shares with the caricaturist the joy of dwelling upon peculiarities of human make-up and delving into the science of physiognomy: but he only emphasizes, whereas the caricaturist exaggerates.

M. Forain has gone to the halls of justice, to the opera and to the glittering restaurants in search of material, while M. STEINLEN has concerned himself with the artists in the Montmartre district, with the humble toilers of Paris and with the vagabonds who dwell in the regions of the fortifications. Taken together, their drawings preserve for posterity an excellent pictorial record of the manners and customs existing in Paris during their time; this record will be of inestimable value to the political and social historian of the future.

The drawings of M. ForaIN are always immensely entertaining and exciting, and for the artist they are most stimulating companions. Degas always liked to have a lot of them around. Voltaire was right when he defined a bore as one who said everything; no one has ever been bored by a drawing by M. Forain. 
M. ForAIN's interest is in the essentials, which he always emphasizes, and his economy of means is nothing short of marvellous. He faithfully records an incident, strong in characterization, with a dozen strokes of the pen. His drawings, etchings, lithographs and paintings are brilliantly clever in execution, but they are far more than that: they disclose a knowledge and a learning that is profound. Drawing, Ingres has said, does not consist only of lines, but is much more- - expression, the inner form, the structure, the modeling. Daumier and Degas were M. ForaIN's artistic nourrices, but he is absolutely original and his work could never be mistaken for that of another man. His line is alive and even more telling and full of character than that of the greatest Japanese.

It was inevitable that $\mathrm{M}$. ForaIn, like M. Steinlen, should have been completely absorbed by the war and it was likewise a foregone conclusion that the war would react upon him and his art in a powerful manner. A set of perhaps a hundred and fifty lithographs of events and scenes connected directly with the war rank with his most brilliant achiever ments. How gripping and how moving is such a drawing as his lithograph entitled Forward! and how extraordinary is the draughtsmanship!

\section{IV}

M. LuCIEN Jonas, who before the war was known as a painter and an illustrator, is a younger man than either M. STEINLEN or M. ForAiN and is an artist who has come into prominence since 1914. The war brought him inspiration and developed his art. He has made innumerable drawings at the front of types, as well as portraits of generals, most of them quite interesting. However, it is a set of twenty four lithographs entitled The Heroic Soul of France, as well as many other stirring prints of this description, that displays the artist's gifts in their full maturity. M. Jonas is not to be classed with such artists as MM. STEInLEN and ForaIN, for he does not possess their great artistic endowments, but his drawings are probably more popular with the masses than either. Mr. Duncan Phillips has written: "They are compounded of the heart stuff 
of which people's prayers are made in times of need. This is the secret of their success with the French people to-day. M. Jonas explains to them their own fighting idealism." One of the lithographs in the set which shows the heroism of France is entitled A Volunteer, which is not only the best of the series, but also one of the most inspiring drawings which the war has brought forth. An officer of the famous Blue Devil regiment is seen calling for a volunteer to perform some particularly hazardous duty - and every man within sight springs forward for the privilege of giving his life, if need be, to France. Another print shows a blind chaplain struggling along a rough, shell-swept highway carrying on his back a paralyzed soldier, who endeavors to direct his course. Yet another print is of a much bandaged soldier who has been taken prisoner by the Germans and is being interrogated by two offcers. One of these officers, a revolting looking beast, holds a revolver almost against the forehead of the prisoner, who looks him in the eye and replies to his question: "I shall tell nothing."

\section{V}

Lieutenant HENRI FARRÉ has painted some of the most remarkable and authoritative of all the war pictures which have been made. He has depicted the part played by the French aviators in the war and he has painted it most graphically and in a beautiful manner. At the outbreak of the war he was painting portraits in Buenos Aires, but immediately went to France and offered his services to his country. He was attached to the Escadrille de Bombardement with the rank of Observer-Bombardier and subsequently flew over all parts of the Western Front. His most interesting paintings, executed in all cases from notes made as he flew and painted immediately upon landing, have been exhibited in many parts of the United States.

VI

Under the auspices of the French High Commission, several hundred intimate and delightful sketches by French soldier-artists were exhibited [225] 
in many parts of the United States during the years of I9I8 and I9I9.

Quite a large group of drawings in wash and charcoal, with a few in color, were the work of M. Georges Scott, the well-known illustrator. His sketches and drawings, well executed and full of fire, are scenes in the trenches and on the battlefield. One is called Gloire au Soldat de France, another Offensif en Champagne, another Patrols. A beautiful drawing in pen-and-ink and water'color entitled Watchers at the Foot of Tofana shows two men in a trench, a high mountain covered with snow being in the background. Some very strong water'color studies of soldiers both back of the lines and in the trenches, were by M. RENEFER. Other excellent drawings of soldier types were by M. BERNARd NAUdIN and M. Rogerde Valerio. Amusing little lithographs of children play, ing soldier were by $\mathrm{M}$. Pоulвoт. Other good drawings were by MM. Lucien Jonas and A. Boisfleury. Mr. Royal Cortissoz well summed up the impression conveyed by these delectable sketches when he wrote: "It is not, indeed, of artistic ambition at all that we are conscious as we survey these souvenirs of the war. It is, instead, of everyday human traits, of brave men relieving an intolerable routine with unpretentious artistic excursions, dashing off slight memoranda of dreary scenes, affirming not so much dexterity of hand as a simple manly courage."

Early in I9I9 a collection of seventy'seven paintings by French artists, twenty-five in number, were placed on view in one of the New York galleries. They were the work of M. E. Louis Gillott, official artist of the French army, M. Charles Fouqueray, official painter of the Musée de l'Armée, several pupils at the École des Beaux/arts and other artists. But few of them possessed very great interest.

Hundreds of small drawings, mostly in water'color, the work of former students of the École des Beaux-arts, were sent to America to be sold for the benefit of the families of artists who had been wounded or killed in the war. Many of these sketches were extremely well drawn. This excellent work was carried out by Mr. Henry Renwick Sedgwick, of New York. 
Thirty paintings by M. JEAN GAUTIER, representing personal experiences of the artist in the battles of Verdun and the Marne, were shown in New York in March, 1919, and proved to be fairly interesting.

Many fine and spirited drawings by MM. Françors FlaMeng, Charles Huard and Grorges Scott, all official artists, have appeared in the pages of L'Illustration.

\section{VII}

As was to be anticipated, the finest war posters have come from France, where the artistic poster was originally conceived and brought to great perfection. It has been well said that the inspiring French war posters are "an intimate expression of the greatest convulsion in the history of civilization."

None of the French posters have been more effective or artistic than those of M. SteINLEN: hisdesigns are masterpieces of poster craft, simple, straightforward drawings, of which the lettering is by him and forms an integral part, and posters which serve their purpose well by telling their story in an unmistakable and forceful manner. In his poster entitled L'Aisne Dévastée, which is an appeal for funds for a charity interested in the reconstruction of destroyed homes, we see a young mother grasping her two small children to her side. A completely ruined house in the background completes the picture, the pathos of which surely could have been rendered by no one else as well as M. STEINLEN. In La Triennale, a poster designed to advertise an exposition of French art held for the benefit of the Fraternite des Artistes, we perceive the magnificent and undaunted figure of an older and bearded soldier gazing at a man ploughing with a pair of great white oxen, preceded by a figure of Victory. Other superbly drawn figures of the invincible French soldiers appear in a poster entitled Concert en Grange and Pendant Qu'Arsene se Bat, while in a poster issued by the Serbian Relief we have a most tragic procession of halfstarved refugees.

M. Forain's poster entitled Le Vêtement du Prisonnier de Guerre contains the figure of a seated soldier, a prisoner, engaged in writing, 
using his right knee as a table. The drawing of this soldier has been done in a most masterly fashion; technically, indeed, the war produced nothing finer than this. Another superb drawing by M. ForaIn appears on the poster issued for a charity known as Le Bon Feu.

No artist of France has had the war react on his art in a more interesting way than "SEM," the famous caricaturist. He designed two posters which take the highest rank among all the posters produced during the war. His two posters entitled Pour le dernier quart d'heure . . . and Pour le triomphe souscrivez à l'emprunt national are simply mag. nificent. In the former print we see a general with his aides watching a regiment of soldiers march by, over a field spotted with shell-holes; in the latter a symbolical view of the Arc de Triomphe which fairly breathes the spirit of ardent patriotism.

Full of fire and spirit and splendidly drawn is M. AbeL FaIVre's poster entitled On les aura! issued for the second government loan, which shows a youthful soldier apparently just going "over the top." It is one of the finest of all the war posters. Another stirring design by M. ABEL FAIVRe is his poster bearing the legend L'Or Combat Pour LaVictoire, in which the cock on an enormous twenty-franc piece is springing out to attack a crouching German soldier.

Other excellent posters are M. Georges Scotr's Pour le Drapeau! Pour la Victoire!M. Willette's Journées Girondines and M. Poulbot's N'oublie pas de souscrire ... pour la Victoire!... et le retour! to mention but a few more of the many excellent posters which have been produced in France.

MM. Guy Arnoux, Benito and Hermann Paul have made some most interesting drawings to commemorate certain events of the war, such as the arrival of the American troops in France and the work of the American Red Cross. These charming designs, which are issued singly, have been drawn after the manner of old French woodcuts and broadsides and are printed in color. 


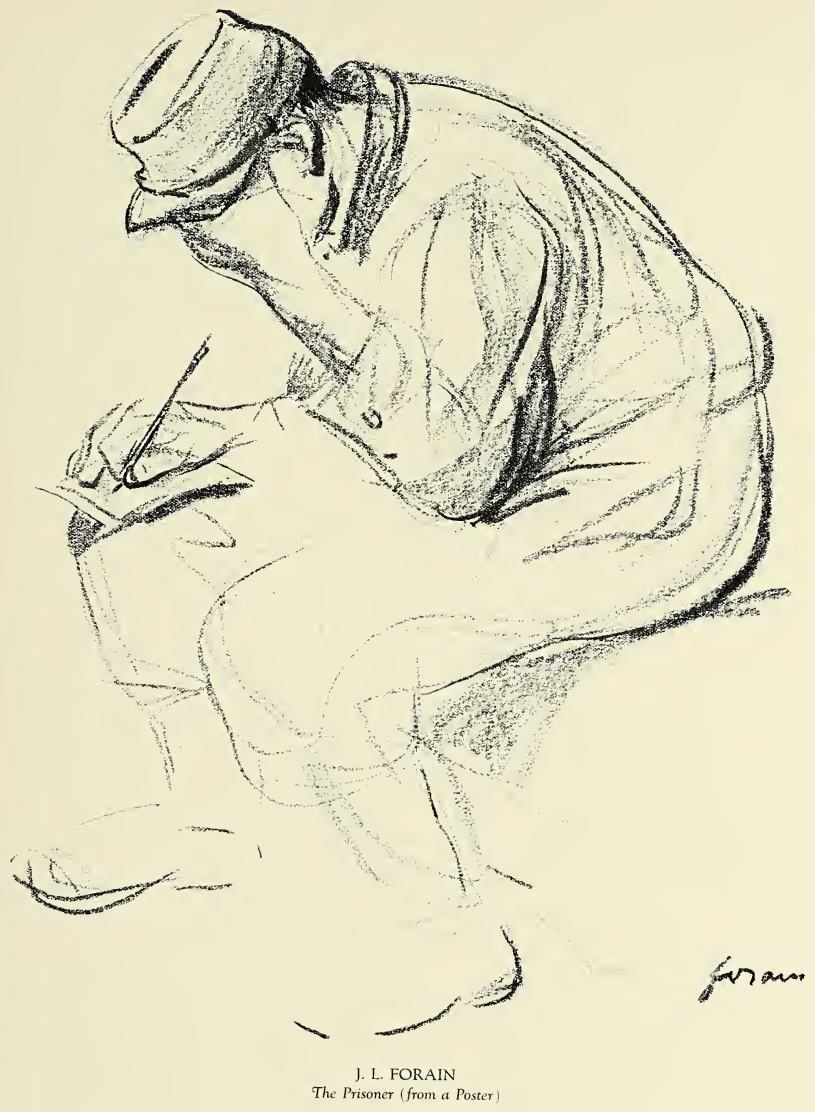





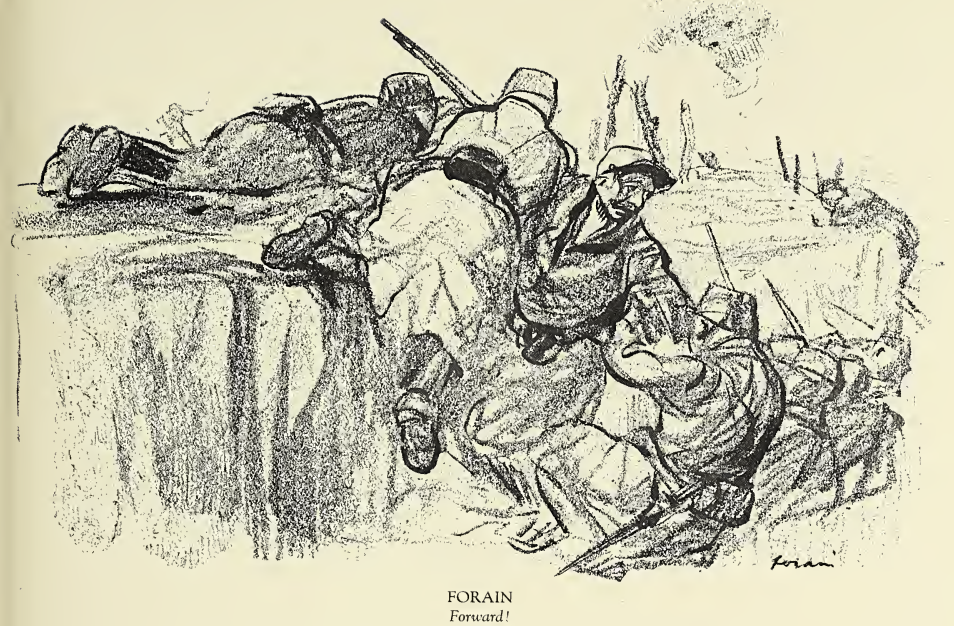





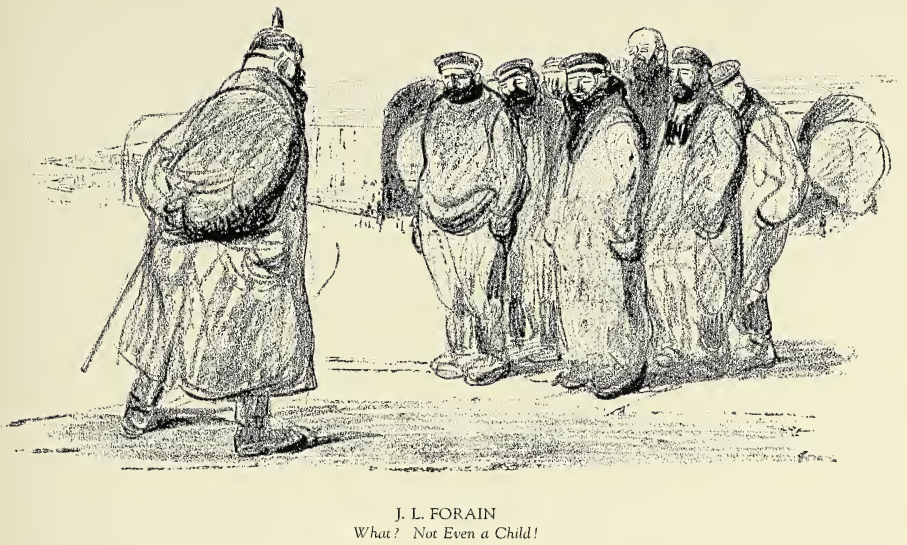





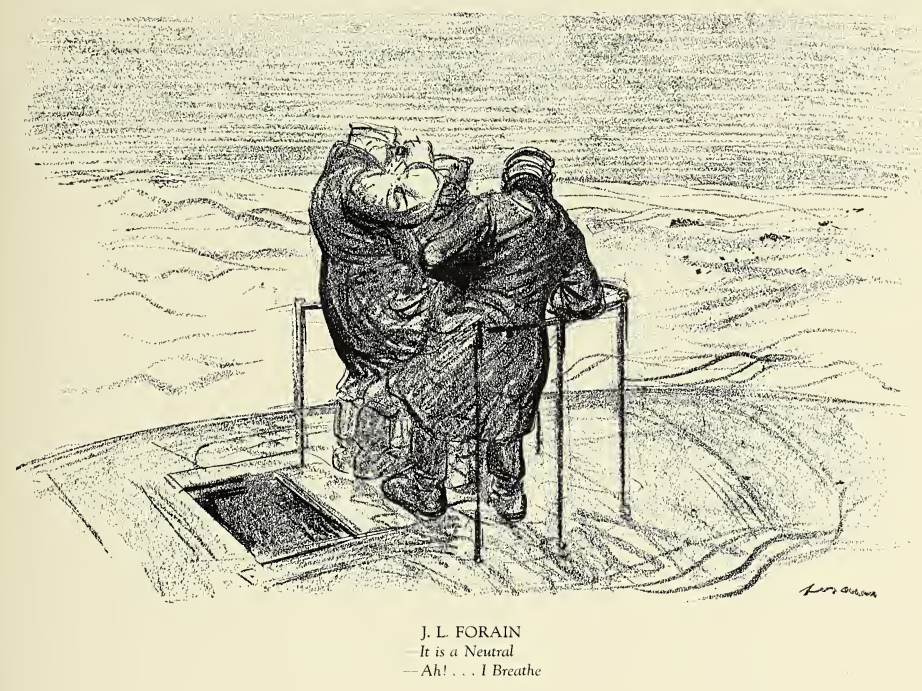





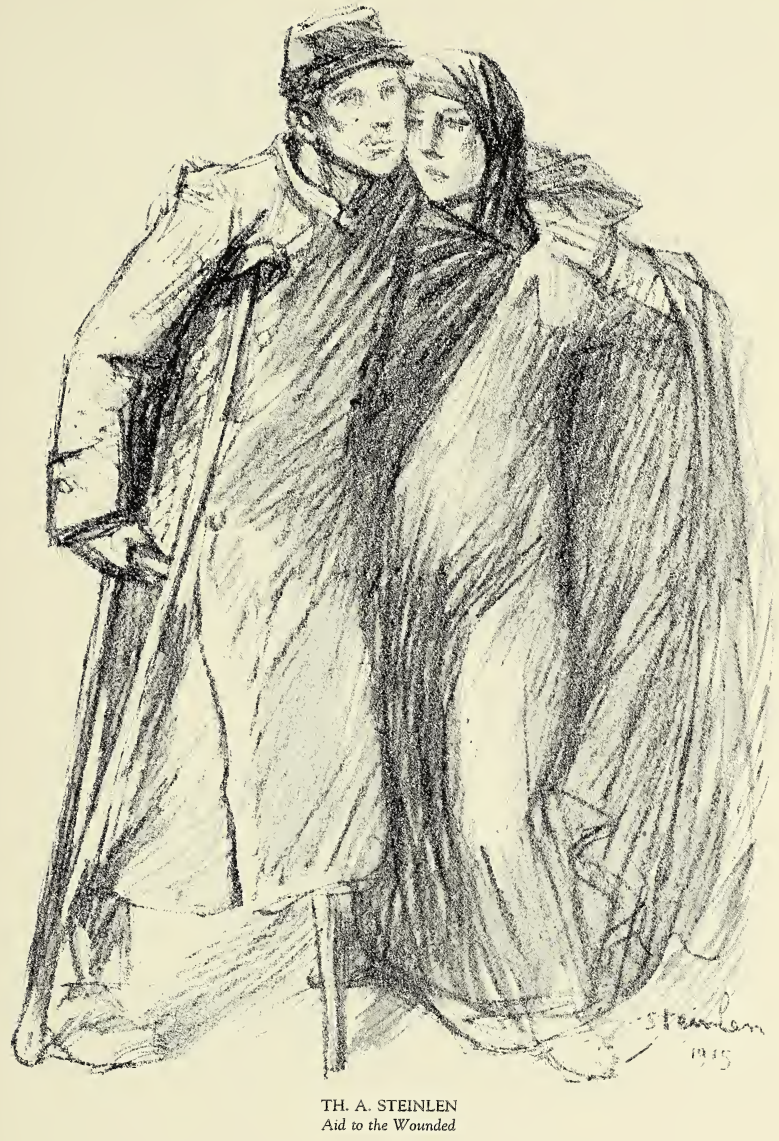





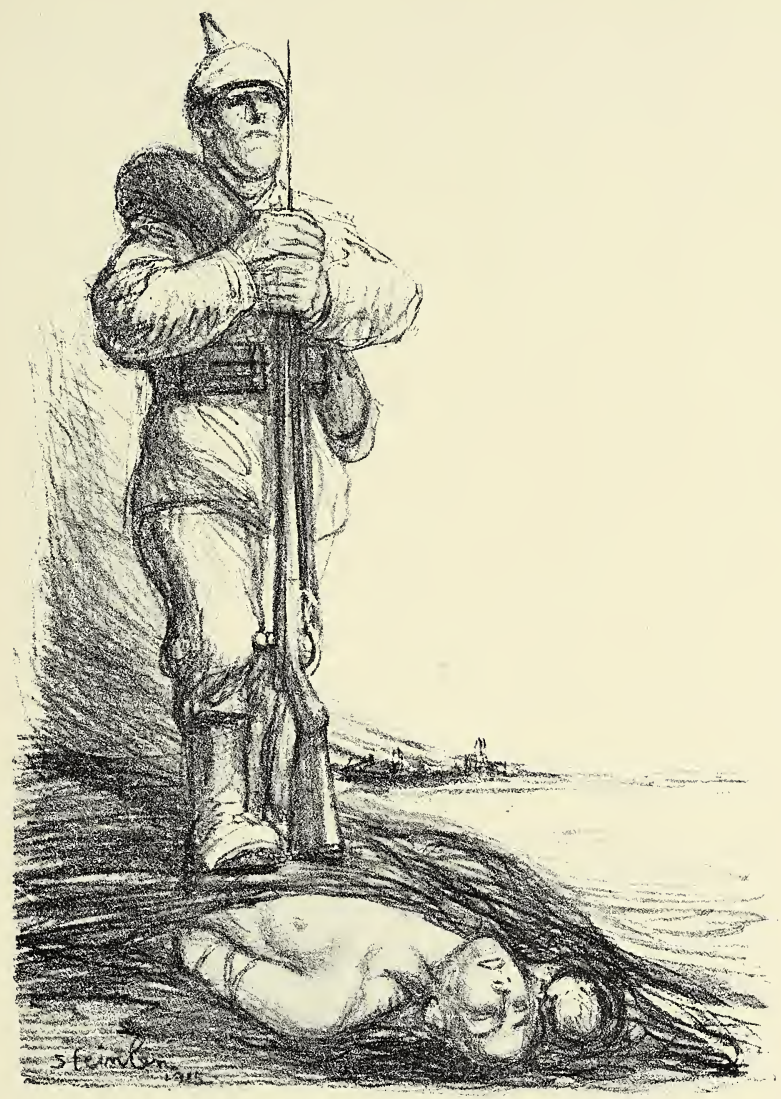

TH. A. STEINLEN

Under the Boot 



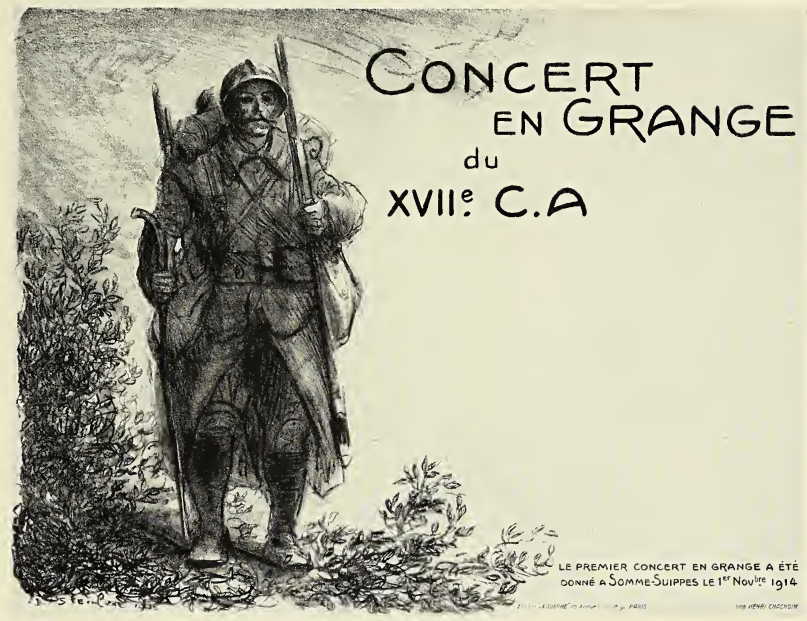

TH. A. STEINLEN

Concert en Grange 



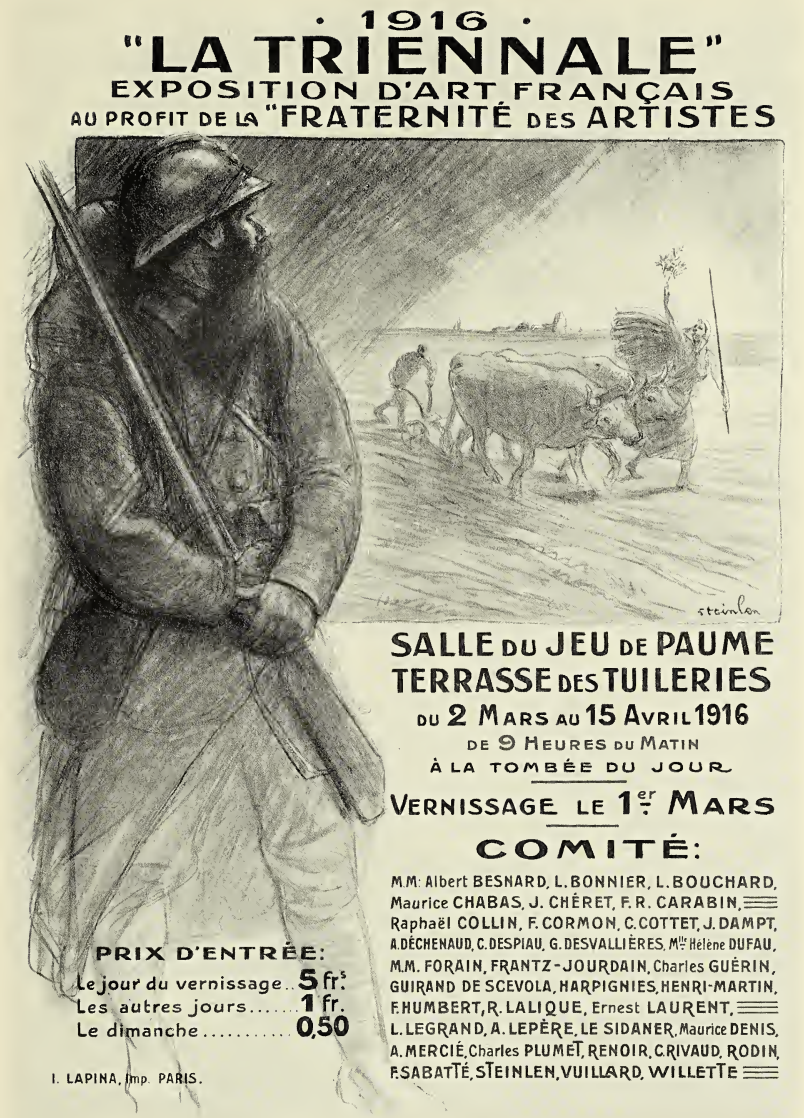

TH. A. STEINLEN

La Triennale 



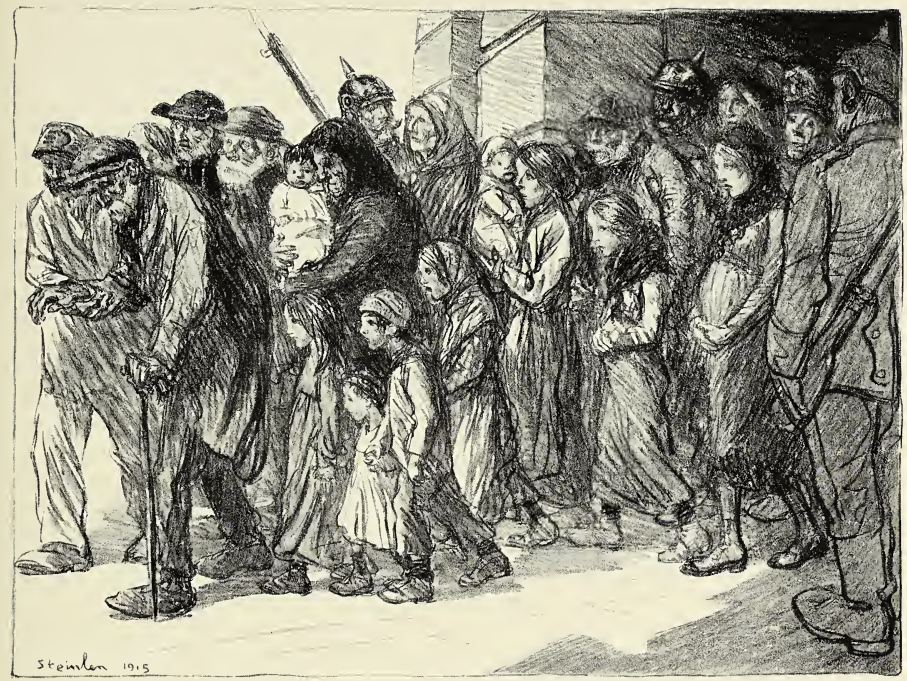

TH. A. STEINLEN

Leaving the German Jail 



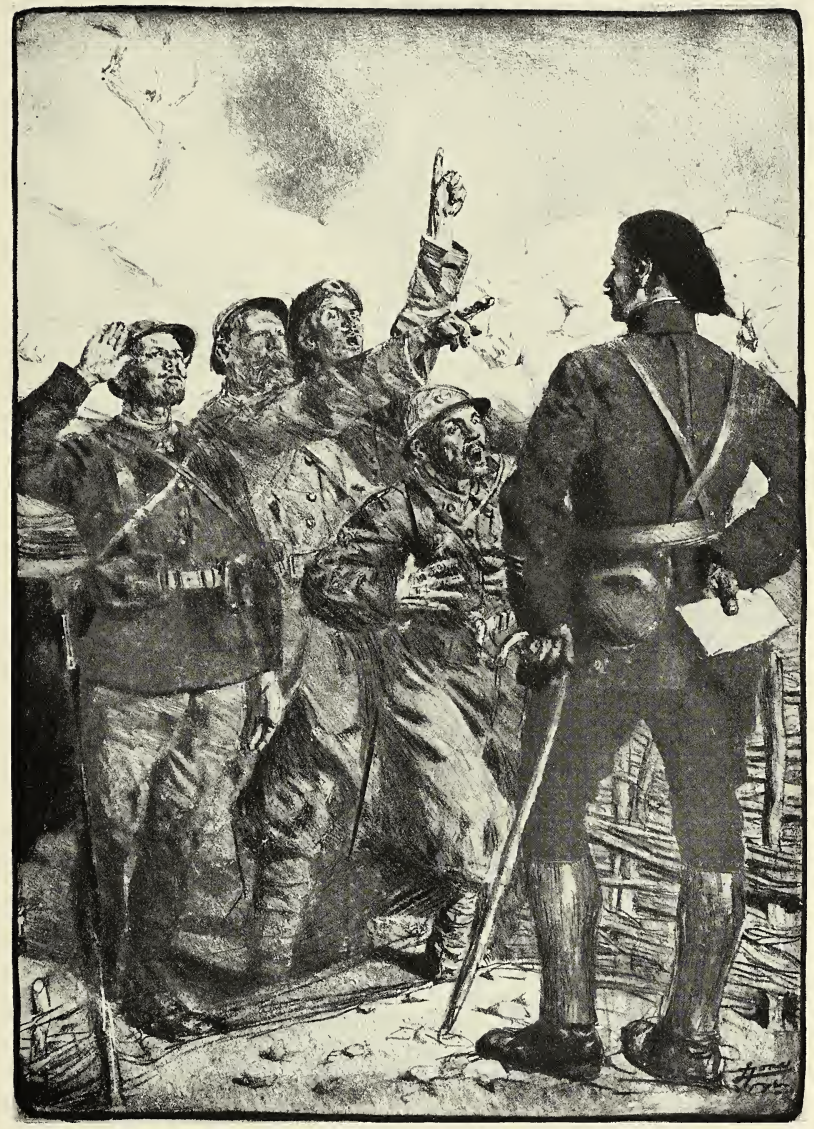

LUCIEN JONAS

A Volunteer 


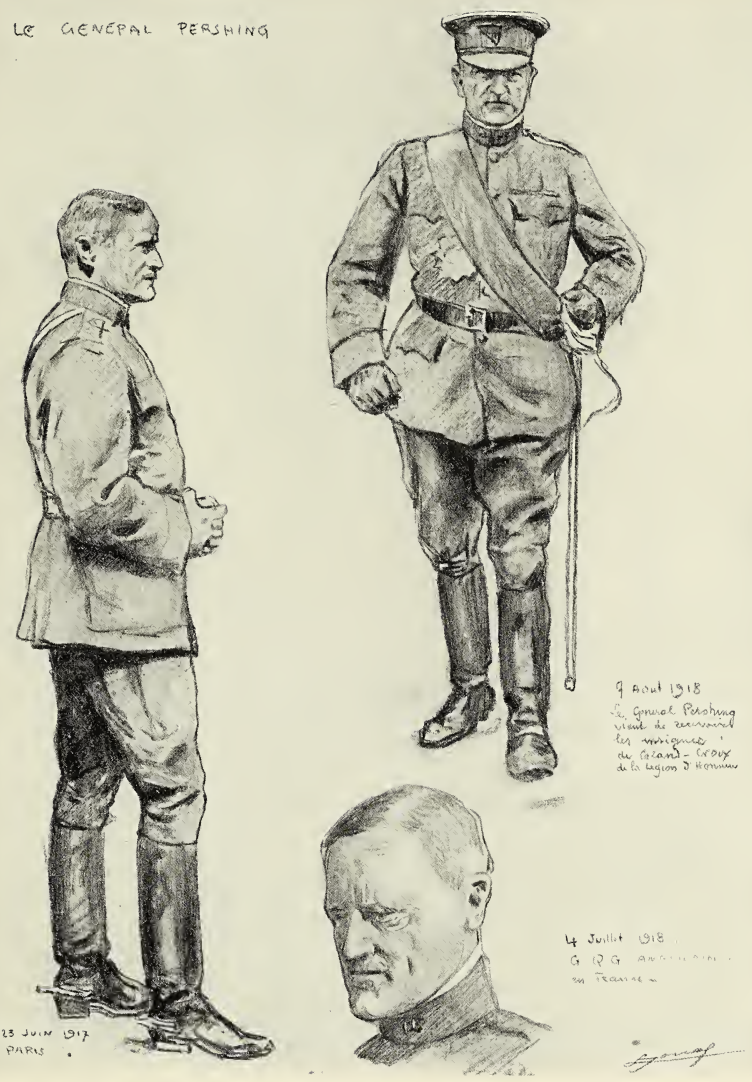

LUCIEN JONAS

Portraits of General Pershing 



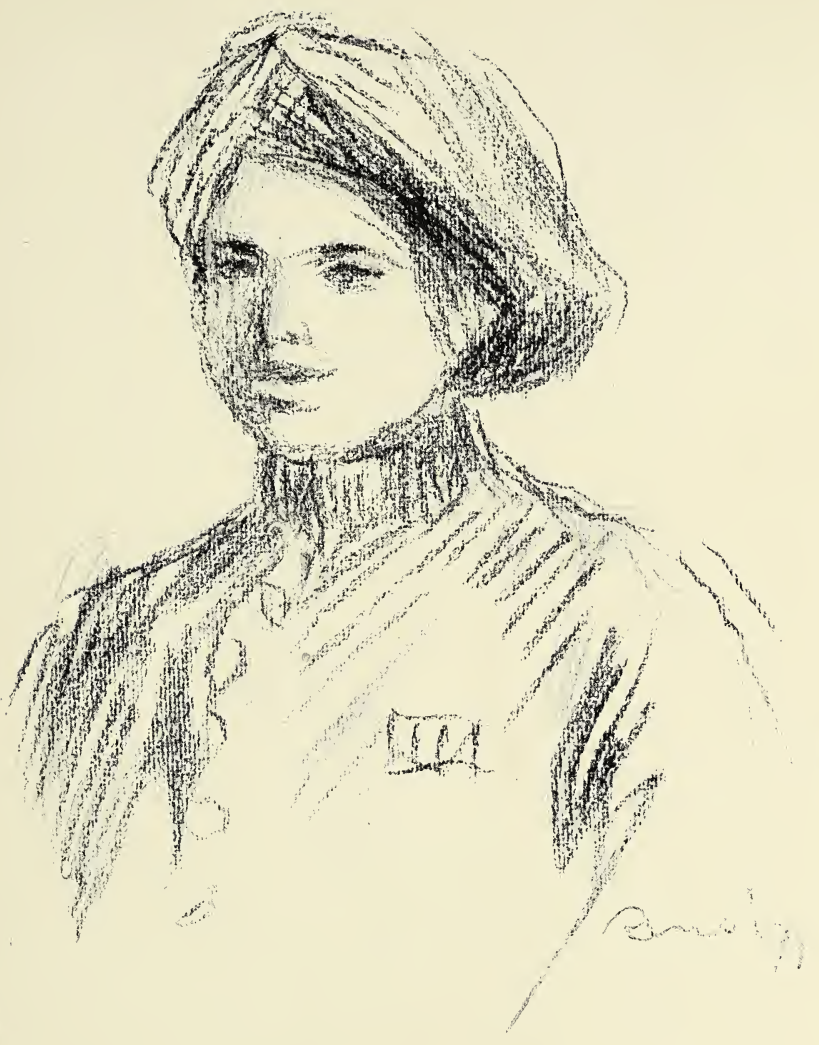

PIERRE AUGUSTE RENOIR

Portrait of His Son, Wounded in the War 



\section{LES HYMNES ALLIÉS}

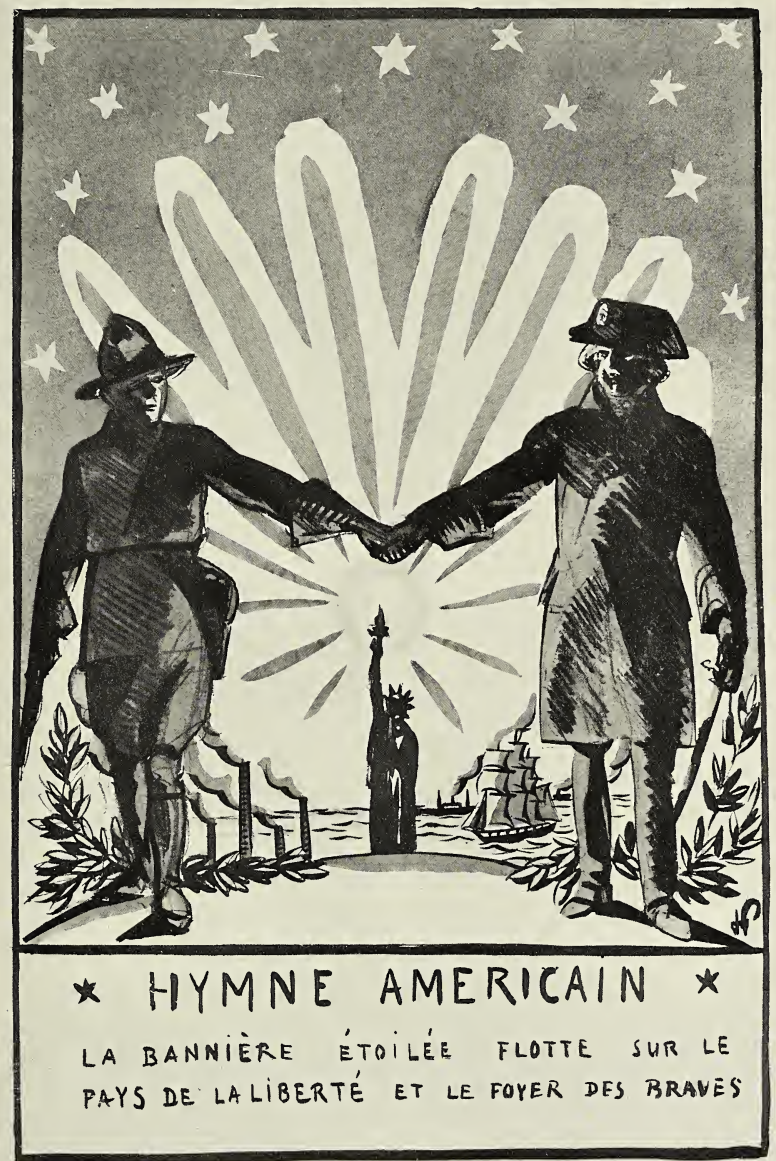

Image de Hermann Paul, tirée ä 1.000 exemplaines, Editee ä PARIS, par le NourEL EssoR, 40 , rue des S? Rères. 



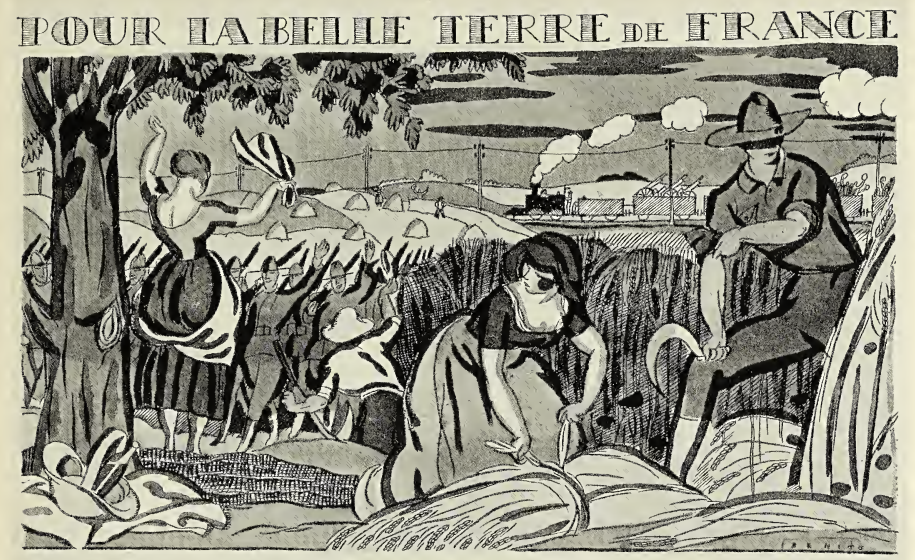

"Paysans de France, saluons les soldats de la libre A mérique qui viennent par millions mêeler leur sang à celui de nos lilk, pour nous conserver le droit de cultiver notre champ et pour empècher les barbares de nous ravir les libertés conquises. n

BENITO

For the Beautiful Land of France 



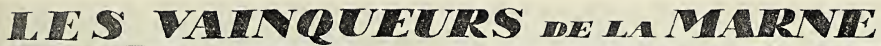

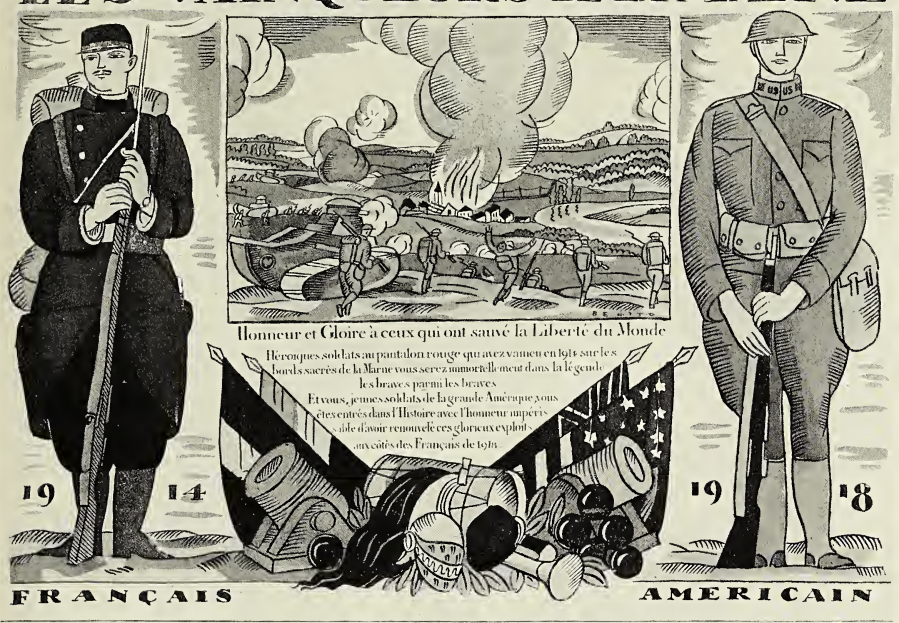

BENITO

The Conquerors of the Marne 



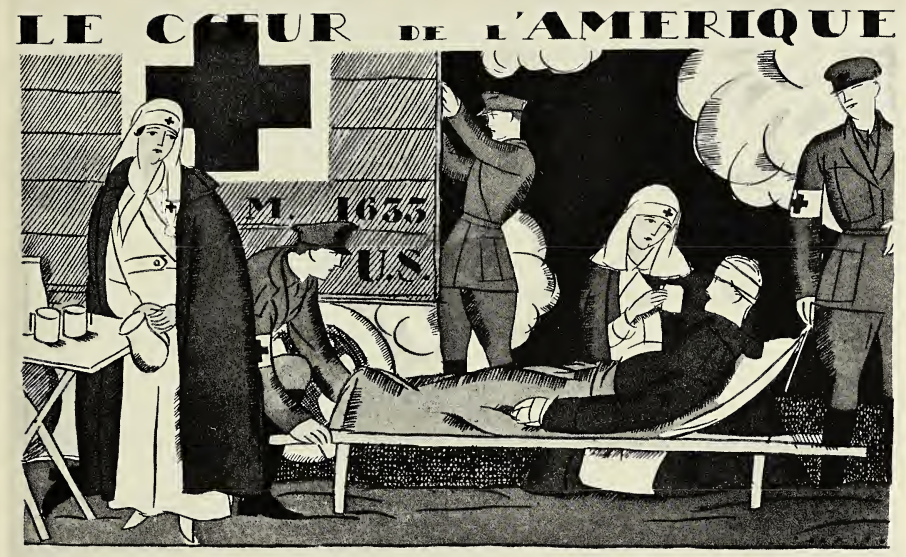

A l'intérieur comme aux armées, aucune souffrance ne laisse indifférente $\mathrm{l}_{\mathrm{a}} \mathrm{C}_{\text {roix- }} \mathrm{R}$ ouge américaine. 



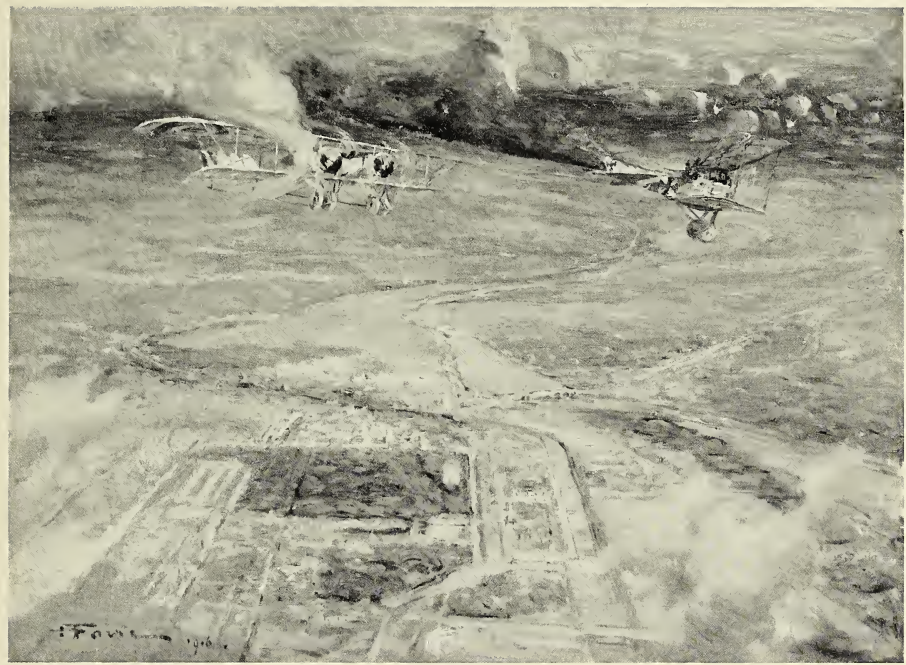

HENRI FARRÉ

Bombing Nancy 



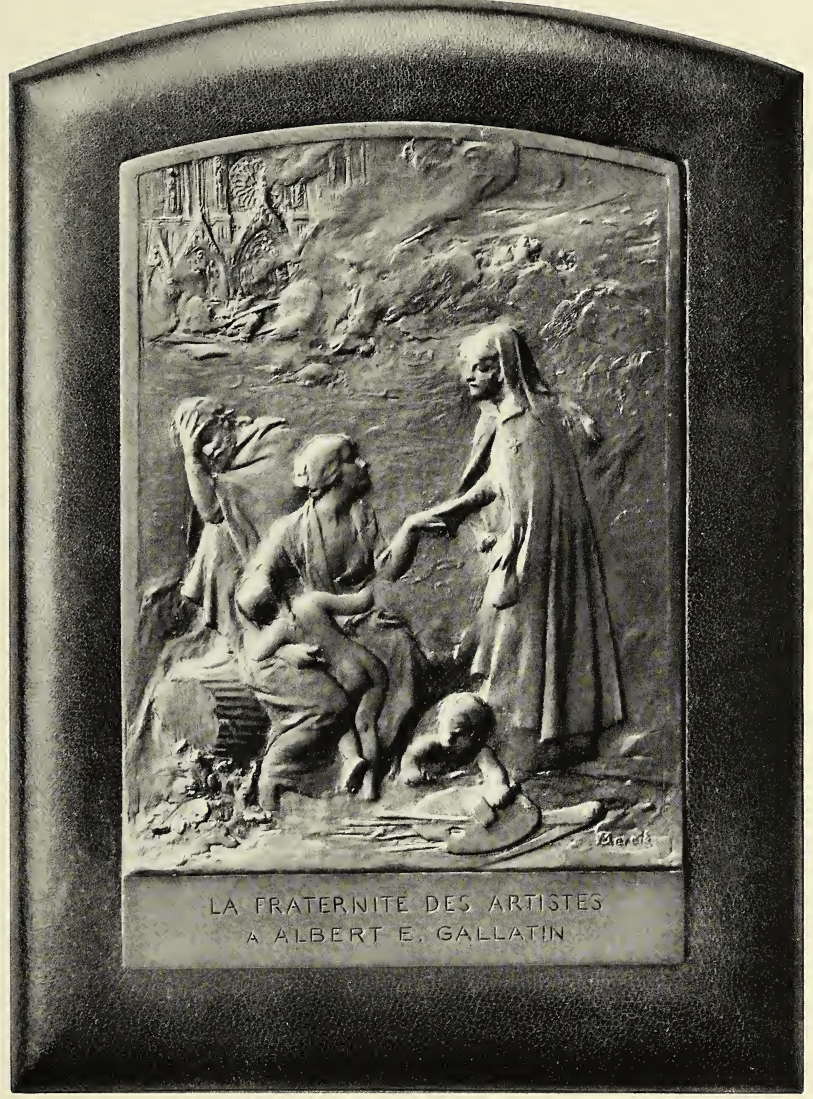

ANTONIN MERCIE

Plaquette de la Fraternité des Artistes 




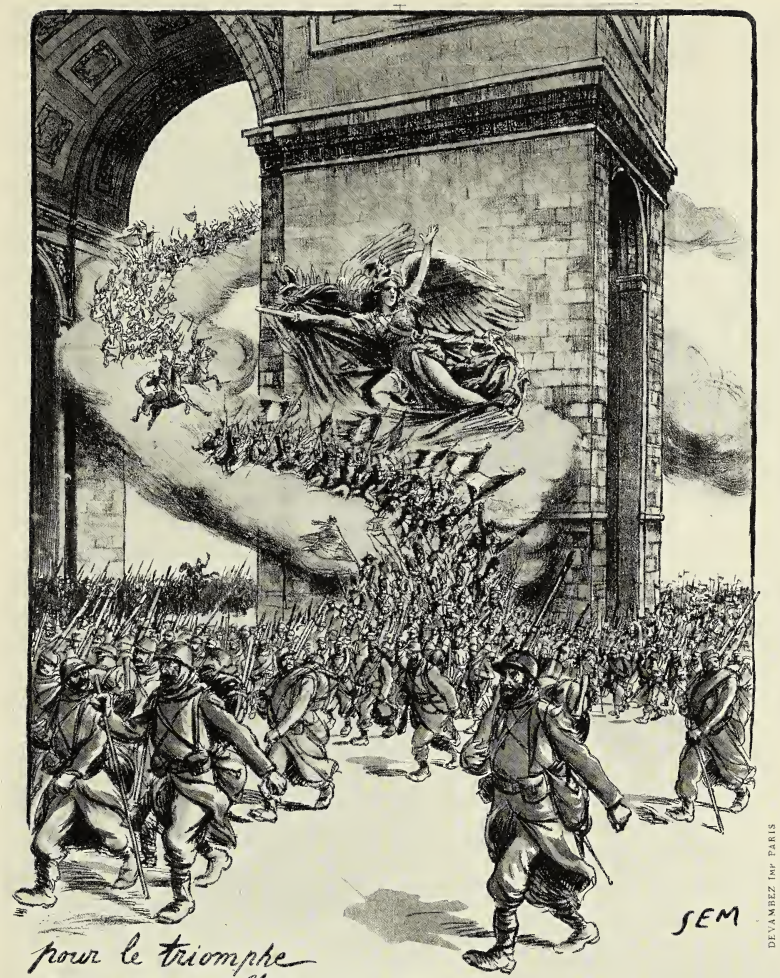

Houscivez a Pemprent national

Les Souscriptions sont Reçues a PARIS eт вn Province BANQUE NATIÔNALE ${ }_{\text {DE }}$ CRÉDIT

Pour le Triomphe Souscrivez à l'Emprunt National 



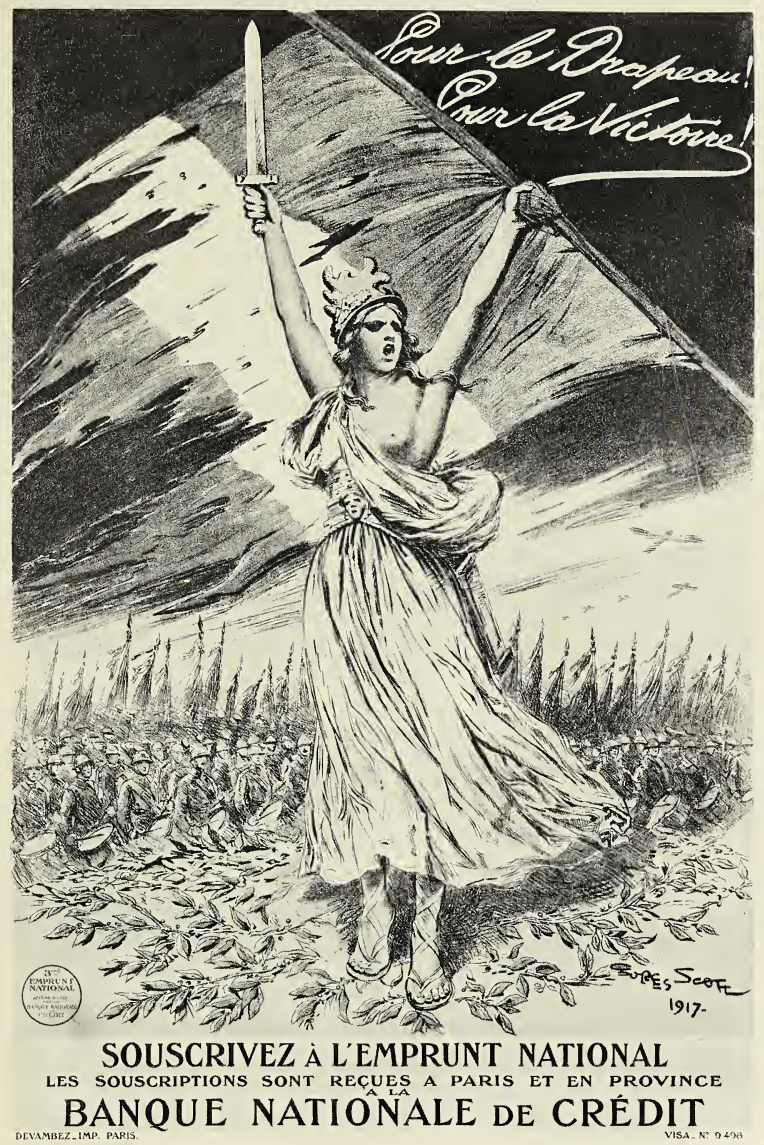

GEORGES SCOTT

Pour le Drapeau! Pour la Victoire! 

On les aura!

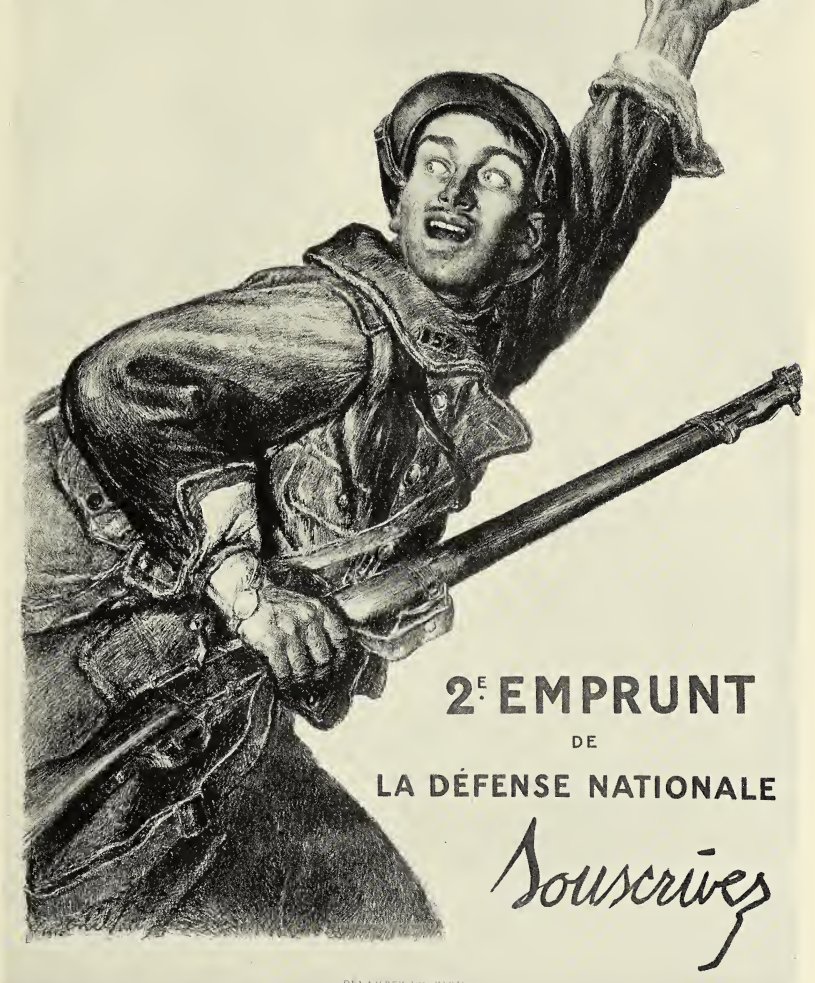

ABEL FAIVRE

On les Aura! 



\section{Pour la France VERSEZ VOTRE OR}

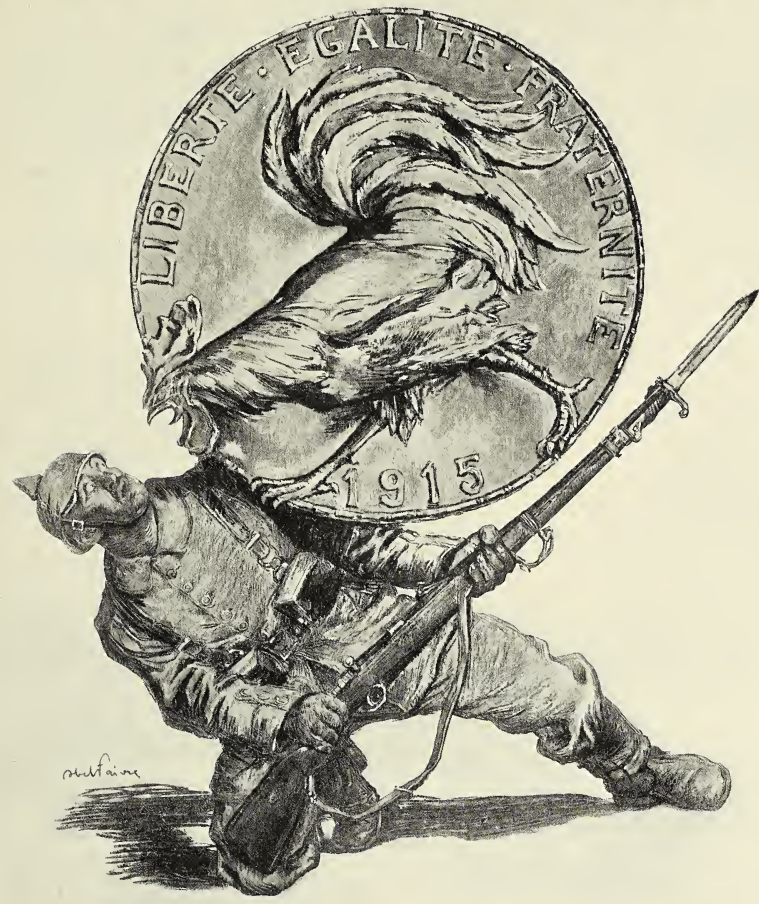

\section{L'Or Combat Pour LaVictoire}





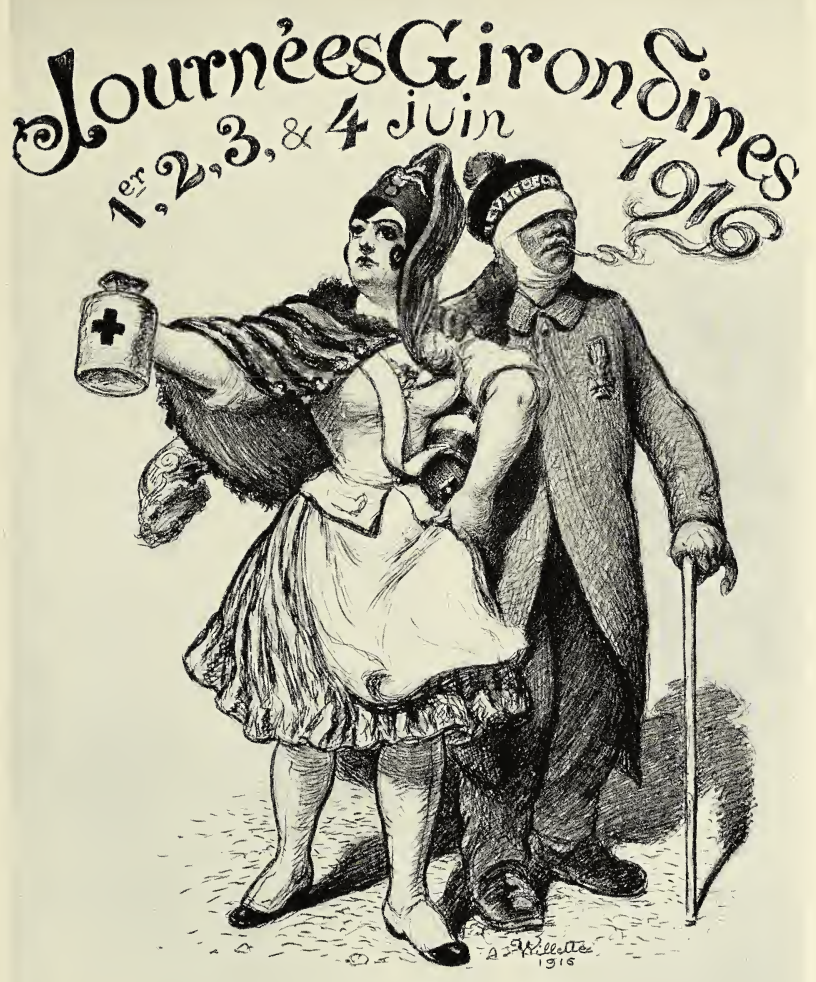

Auprofit Exclusif Des Ceunres de Guerre a departement

ADOLPHE WILLETTE

Journées Girondines 



\section{EMPRUNT ${ }^{\mathrm{DE}} \mathrm{DEE}$ DEENSE NATIONALE}

$+\frac{1}{10}$

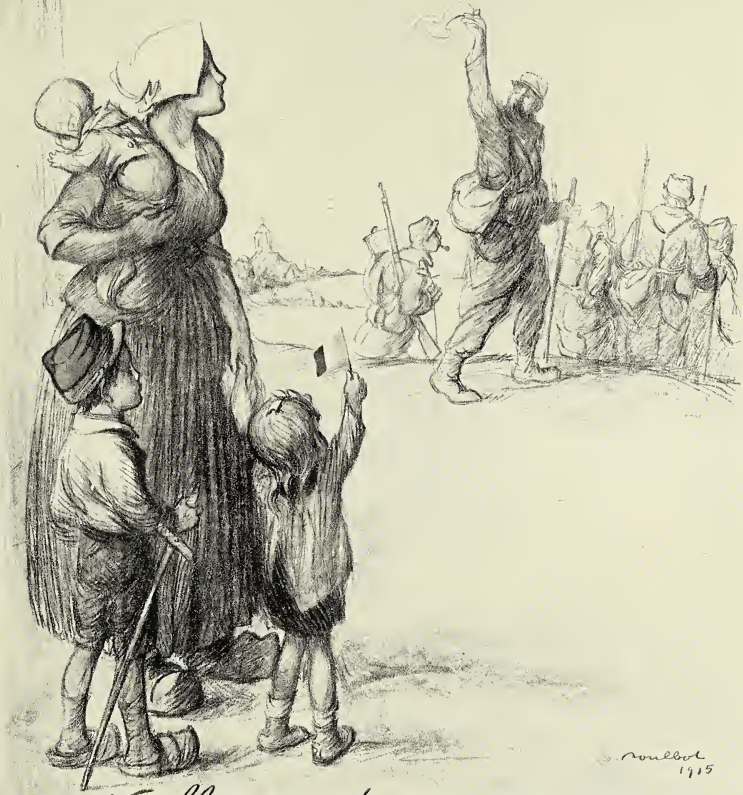

- Noublie pas de soubcire ... pour

PUBUÉ SOUS LES AUSPICES DE LA FÉdÉRATION NATIONALE DE LA MUTUALITÉ FRANCAISE QUI FAIT APPEL A TOUS LES TRAVAILLEURS. A TOUS LES PREVOYANTS. A TOUS LES PATRIOTES POUR LA LIBÉRATION DU TERRITOIRE ET LA VICTOIRE FINALE.

FRANCISQUE POULBOT

-Noublie pas de souscrire... pour la Victoire! ... et le retour! 

THE NETHERLANDS 



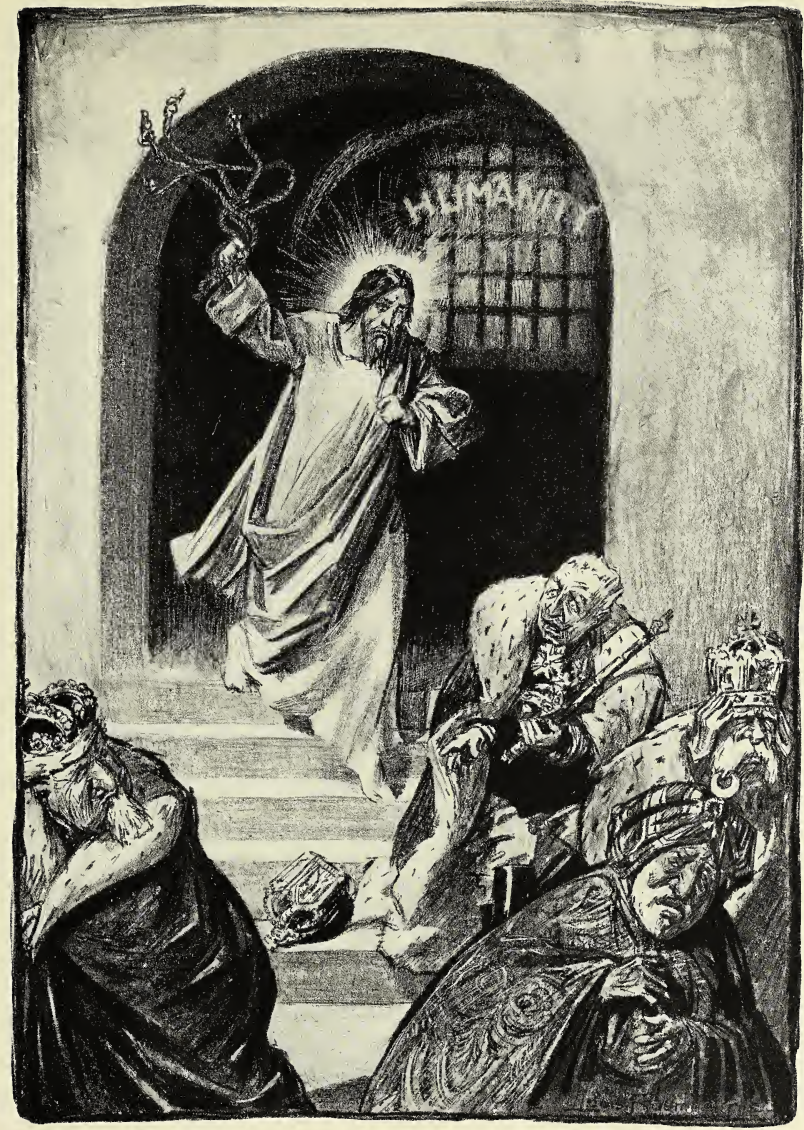

LOUIS RAEMAEKERS

Cleansing the Temple 



\section{BIBLIOGRAPHY}

\section{THE UNITED STATES OF AMERICA}

\section{General and Miscellaneous}

International Cartoons of the War. Selected with an introduction by $\mathrm{H}$. Pearl Adam. New York: E. P. Dutton \& Co., N. D.

Art ANd the War. By Duncan Phillips. Illustrated. The American Magazine of Art (Washington), June, r918.

Amrrican Artists and the War. By A. E. Gallatin. Valentine's Manual (New York), I9I8.

A Check List of the Literature and Other Material [Including Posters and Cartoons] in the Library of Congress on the European War. Washington: Government Printing Office, 19r8.

Joserh Pennell's Pictures of War Work in America. Thirty-six plates and an introduction. Philadelphia and London: J. B. Lippincott, rgr8.

Suggestions for Artists Desiring to Apply Their Knowledge to War Work. By A. E. Gallatin. New York: The Mayor's Committee on National Defense, I9r8.

The Value of Landscape Targets. By Captain J. R. Cornelius. Illustrated. Scribner's Magazine (New York), October, I918.

New Faces for Mutilated Soldiers. By Grace S. Harper. Illustrated. Red Cross Magazine (Garden City, New York), November, I9r8.

Alited War Salon. Catalogue. With an essay by A. E. Gallatin entitled Art and the War and eighteen illustrations. New York, r9ı.

Pictures of the Great War. Catalogue. Some of the exhibits from the Allied War Salon. A. E. Gallatin's essay on Art and the War reprinted. Pittsburg: Carnegie Institute, I9I9.

The War's Influence on Art. By Herbert Adams. The Forum (New York), Jan, uary, I9I9.

The Allied War Salon. By Duncan Phillips. Illustrated. The American Magazine of Art (Washington), February, I9I9.

Division of Pictorial Publicity. Souvenir menu of a banquet held in New York, ith February, I919. A history of the Division of Pictorial Publicity, containing fifty. six miniature reproductions of posters. New York, privately printed, I9I9.

Reproductions of Drawings showing the American Troops in Action. By Lester G. Hornby. Harper's Magazine (New York), March, April and May, r9ig.

Drawings made in France by the Ofpicial Artists of the United States Army. Reproduced in Scribner's Magazine, Century Magazine, and Everybody's Magazine (New York), March, I9I9. 
A Day with a Sketch-book on The Front. By Will Foster. Illustrated. Scribner's Magazine (New York), April, i9i9.

Practical Patriotism in American Art. By Carter Glass. Illustrated. Art and Life (New York), June, igig.

WAR Memorials. Entire issue of The American Magazine of Art (Washington), September, I9I9.

Pictorial Records of the War. A lecture delivered at the Metropolitan Museum of Art, New York. By A. E. Gallatin. The American Magazine of Art (Washington), October, I9I9.

The War in Cartoons. Edited by George J. Hecht. Ioo illustrations. New York: E. P. Dutton छ' Co., I919.

\section{Posters}

Posters and War Work. By Helen Wright. Illustrated. The International Studio(New York), June, 1918.

Making Posters Fight. By Montrose J. Moses. Illustrated. The Bookman (New York), July, I9r8.

Posing the War for the Panter. By Robert Cortes Holliday. Illustrated. The Book man (New York), July, r9r8.

Our Fighting Posters. By Julian Street. Illustrated. McClure's Magazine (New York), July, 1918.

The Story of the War Posters. By H. A. McDonald. Illustrated. Sea Power (New York), August-November, I918.

Joseph Pennell's Liberty Loan Poster. By Joseph Pennell. Illustrated. Philadelphia : J. B. Lippincott Co., 1918.

Posters Issued by the United States Navy. Illustrated. New York: U. S. Navy Recruiting Bureau, I918.

Official Posters. United States Shipping Board Emergency Fleet Corporation. Illus. trated. Philadelphia: Publications Section, I918.

The Poster's Part in the Great War. By Adolph L. Feuerlicht. Illustrated. The Poster (Chicago), February, I9I9.

\section{Camouflage}

Notes on Camouplage. By J. André Smith. Illustrated. The Architectural Record (New York), November, I9I7.

Nature's Camouflage and Man's. By Aymar Embury, II. Illustrations in color by Charles Livingston Bull. The New Country Life (Garden City, N. Y.), June, I918.

Camouflage. By Abbott H. Thayer. The Scientific Monthly (New York), December, I9I8. 
Marine Camouflage. By Robert Cushman Murphy. Illustrated. Sea Power (New York), January, I9I9.

Marine Camouflage Brought to Perfection in America. By Lindell T. Bates. Illus, trated. The Sun (New York), ig January, igrg.

The Science of Camouflage [Marine] Explained. By Raymond Francis Yates. Every. day Engineering Magazine (New York), March, I9Ig.

\section{GREAT BRITAIN}

Punch Cartoons of the Great War. An album of reproductions. New York: George H. Doran Co., 1915.

The Western Front. By Muirhead Bone. Two hundred drawings, in ten parts. London: Country Life, Ltd., and George Newnes, Ltd.; Garden City, New York: Doubleday, Page and Co.; New York: George H. Doran Company, I9I7.

Modern War. Painting by C. R. W. Nevinson. With an introductory essay by P. G. Konody. Illustrated. London: Grant Richards, Ltd.; New York: Robert M. McBride and Co., I9I7.

British Artists in the War Zone. Muirhead Bone and James McBey. Illustrated. The International Studio (New York), February, I9I7.

Joseph Pennell's Prctures of War Work in England. With an introduction by H. G. Wells. Fifty॰one plates. London: William Heinemann; Philadelphia: J. B. Lippincott Co., 1917.

The Great War. Britain's Efforts and Ideals Depicted by British Artists. By Malcolm C. Salaman. Illustrated. The International Studio (New York), October, I9I 7.

Admirals of the British Navy. Portraits in Colours by Francis Dodd. Illustrated. New York: George H. Doran Co., N. D.

British Government Exhibition. Official Catalogue [in reality a catalogue of lithographs reflecting Great Britain's efforts and ideals in the Great War]. Introduction by James Walter Smith. Illustrated. New York: British Information Bureau, I9I8.

The Great War-Fourth Year. Paintings by C. R.W. Nevinson. With an introduc, tory essay by J. E. Crawford Flitch. Illustrated. London: Grant Richards, Ltd., I9I8.

British Artists at the Front. i. C. R. W. Nevinson. With introductions by Campbell Dodgson and C. E. Montague. 2. Sir John LAvery. With introductions by Robert Ross and C. E. Montague. 3. Paul NAsh. With introductions by John Salis and C.E.Montague. 4. ERIC Kennington. With introductions by Campbell Dodgson and C. E. Montague. Each part illustrated with colored plates. London: Country Life, Ltd., and George Newnes, I9I8.

Drawings by James McBey, Official Artist in Palestine. By Malcolm C. Salaman. Illustrated. The International Studio (New York), March, 1918. 
British Artists at the Front. No. i. Sir William Orpen. Caricature, in colors, by Max Beerbohm. Reveille (London), August, 1918.

The Canadian War Memorials. By P. G. Konody. Illustrated. Colour Magazine (Lon. don), September, I918.

Sir William Orpen's War Pictures. By Sir Frederic Wedmore. Illustrated. The Inter, national Studio (New York), September, IgI8.

Artists at the Front. No. 2. Major Augustus John. Caricature, in colors, by Max Beerbohm. Reveille (London), November, 1918.

Reproductions of Drawings by Official Australian Artists. The Graphic (London), I4 December, I9I8.

War Paintings and Drawings by British Artists. Catalogue. Foreword by Raymond Wyer. Introduction by Christian Brinton. Illustrated. New York: British Bureau of Information, I9I9.

Artists at the Front. No. 3. John SARgent. Caricature, in colors, by Max Beerbohm. Reveille (London), February, I9I9.

Canadian War Memorials Exhibition. Catalogue. London: Canadian War Records Office, I9I9.

The Great War. Depicted by Distinguished British Artists. Illustrated. London: The Studio, I9I9.

British W AR Pictures. By Duncan Phillips. Illustrated. The American Magazine of Art (Washington), March, I9ig.

Canadian War Pictures on Exhibition. Illustrated. English Speaking World (New York), July, I9I9.

Dazzle Painting in War-time. By Hugh Hurst. Illustrated. The International Studio (New York), September, rgig.

\section{FRANCE}

Drawings by Official French Artists. Reproduced in L'Illustration (Paris), 1914-1918. Quelques Oeuvres du Front. Illustrated. Les Arts (Paris), No. I71 ; 1918.

La Guerre. Par Steinlen. By Camille Mauclair. Illustrated. Numéro Spécial L'Art et les Artistes (Paris), I9I8.

The Heroic Soul of France-Lucien Jonas' War Lithographs. By Duncan Phillips. The American Magazine of Art (Washington), October, 1918. 
THIS book has been set by BerTha M. Goudy from types and decorations designed by FREDERICK W. GoudY and printed in the shop of WIILIAM E. Rudge, New York City. The engravings were made by the Becr Engraving Company, New York City. 





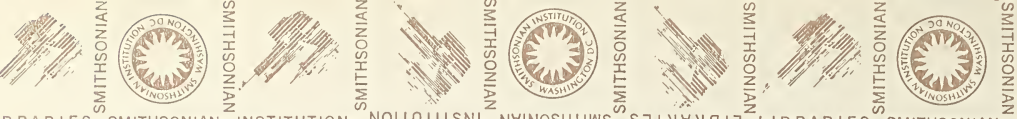

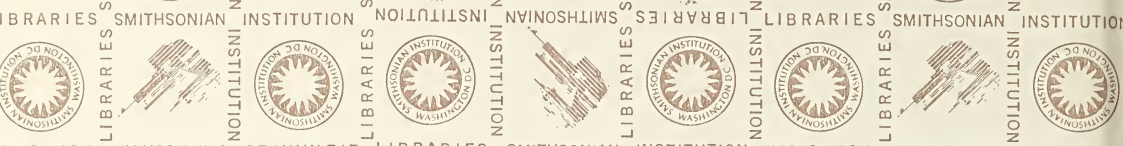

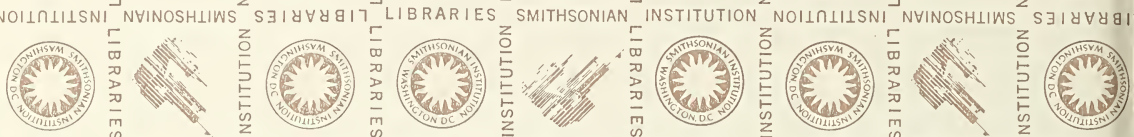

IBRARIES "SMITHSONIAN INSTITUTION NOIINIIISNI NHINOSHIINS

(1)

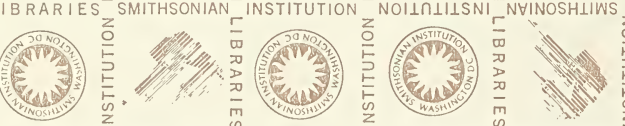
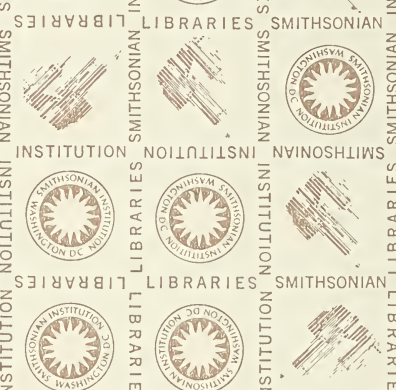

INSTITUTIO|

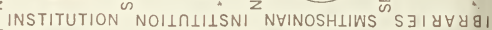
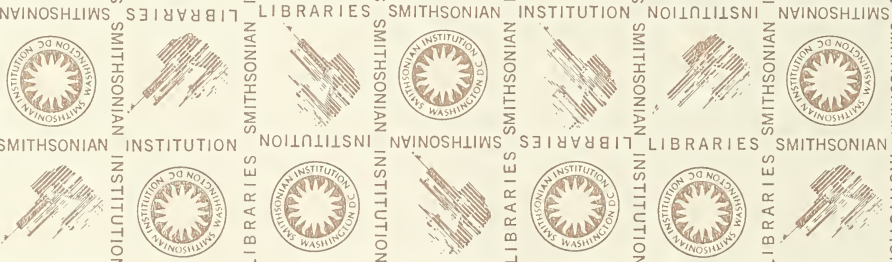

SMITHSONIAN INSTITUTION
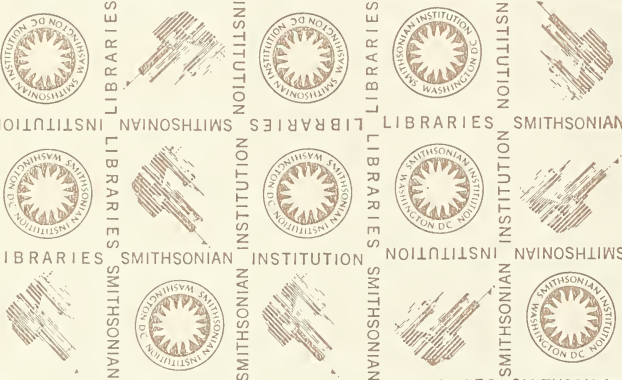

IBRARIES SMITHSONIAN
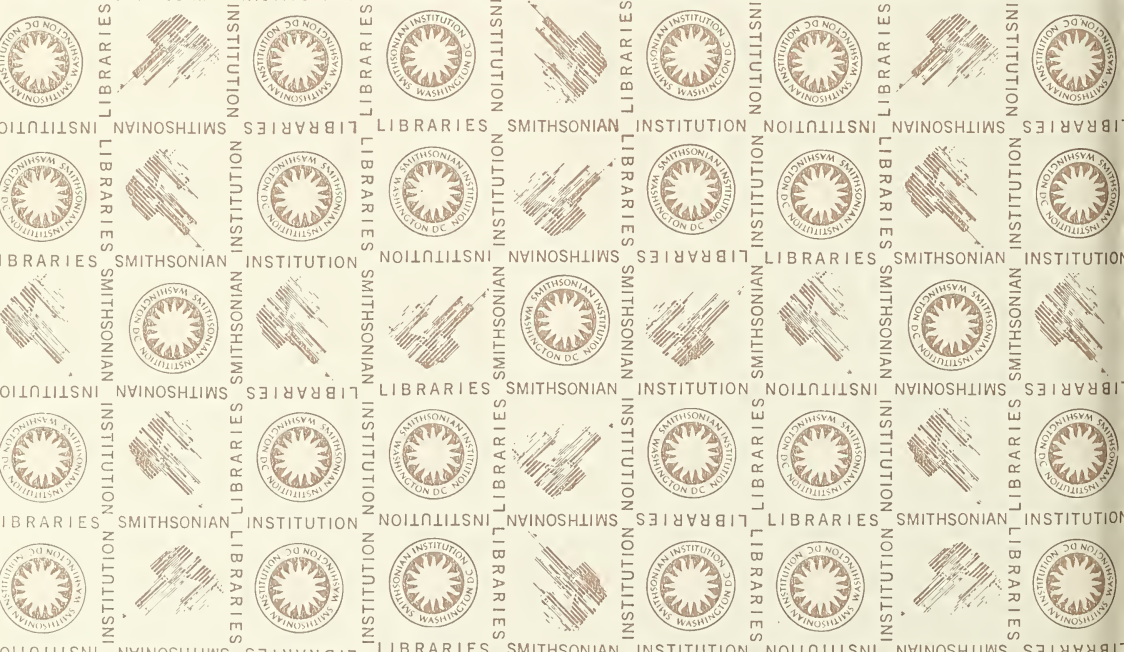

S $\exists I$ y $\forall$ प्व
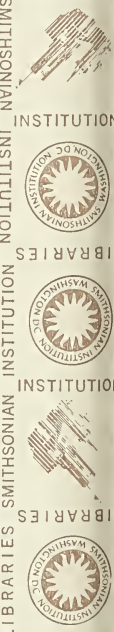

SMITHSONIAN INSTITUTIOI 
(6)

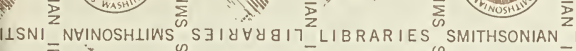

)
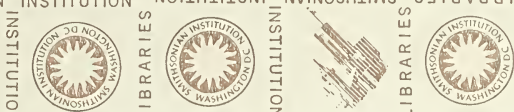

Sivn

RIES
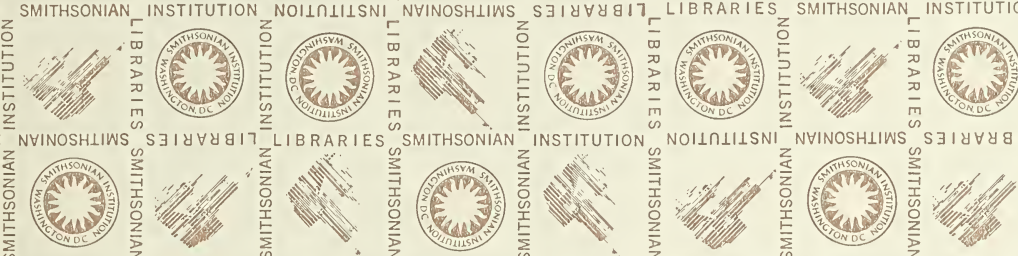

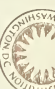
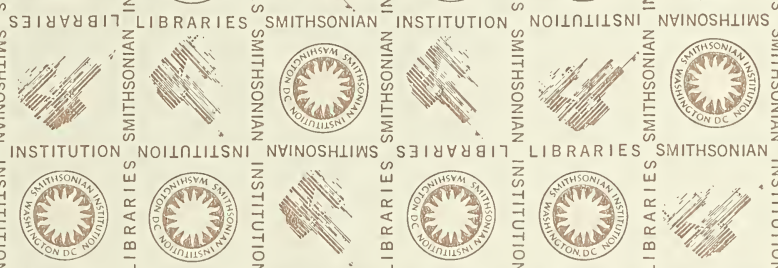

w sivis
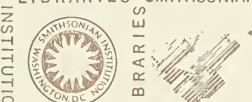

告

sinsw
of
of
ovedu.

IISNI NVINOSHLINS
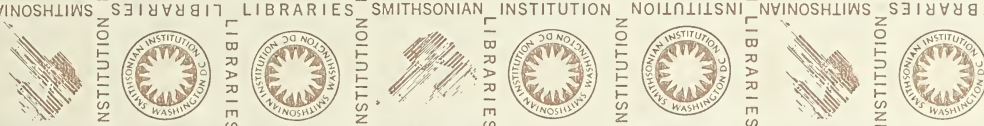

Sim
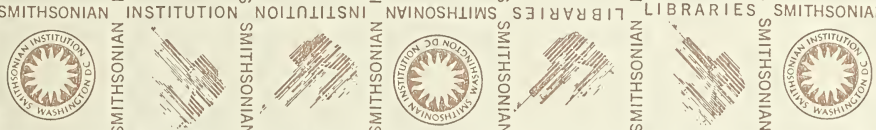

is
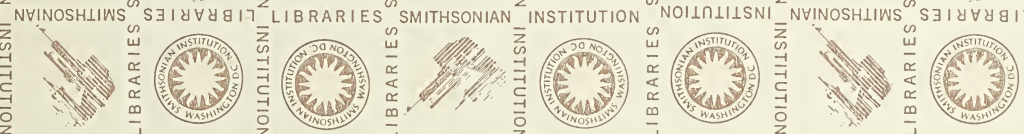

Son
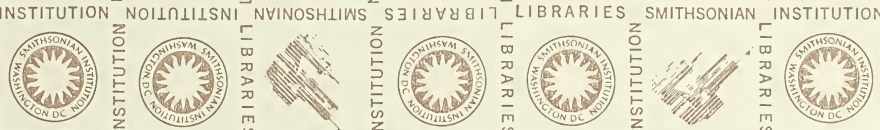

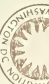
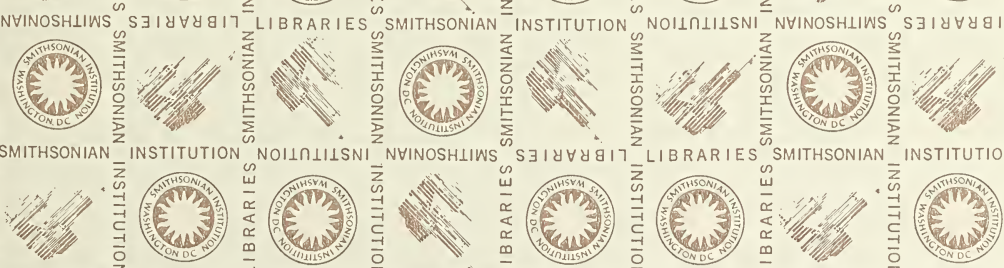

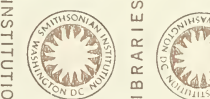

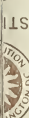

(ampan
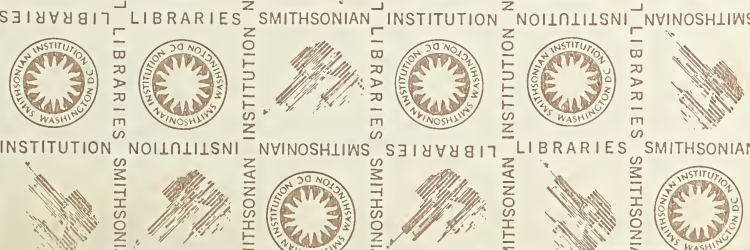

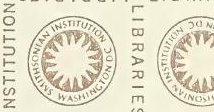

$\leq$

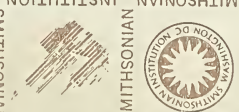

LIBRARIES

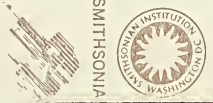


